\title{
Caddo Ceramic Vessels from the T. M. Sanders Site (41LR2) on the Red River in Lamar County, Texas
}

Timothy K. Perttula

Heritage Research Center, Stephen F. Austin State University

Mark Walters

Heritage Research Center, Stephen F. Austin State University

Bo Nelson

Heritage Research Center, Stephen F. Austin State University

Follow this and additional works at: https://scholarworks.sfasu.edu/ita

Part of the American Material Culture Commons, Archaeological Anthropology Commons, Environmental Studies Commons, Other American Studies Commons, Other Arts and Humanities Commons, Other History of Art, Architecture, and Archaeology Commons, and the United States History Commons

Tell us how this article helped you.

This Article is brought to you for free and open access by the Center for Regional Heritage Research at SFA ScholarWorks. It has been accepted for inclusion in Index of Texas Archaeology: Open Access Gray Literature from the Lone Star State by an authorized editor of SFA ScholarWorks. For more information, please contact cdsscholarworks@sfasu.edu. 


\section{Caddo Ceramic Vessels from the T. M. Sanders Site (41LR2) on the Red River in Lamar County, Texas}

\section{Creative Commons License}

\section{(c) (1) \&}

This work is licensed under a Creative Commons Attribution-NonCommercial 4.0 International License 


\section{Caddo Ceramic Vessels from the T. M. Sanders Site (41LR2) on the Red River in Lamar County, Texas}

Timothy K. Perttula, Mark Walters, and Bo Nelson

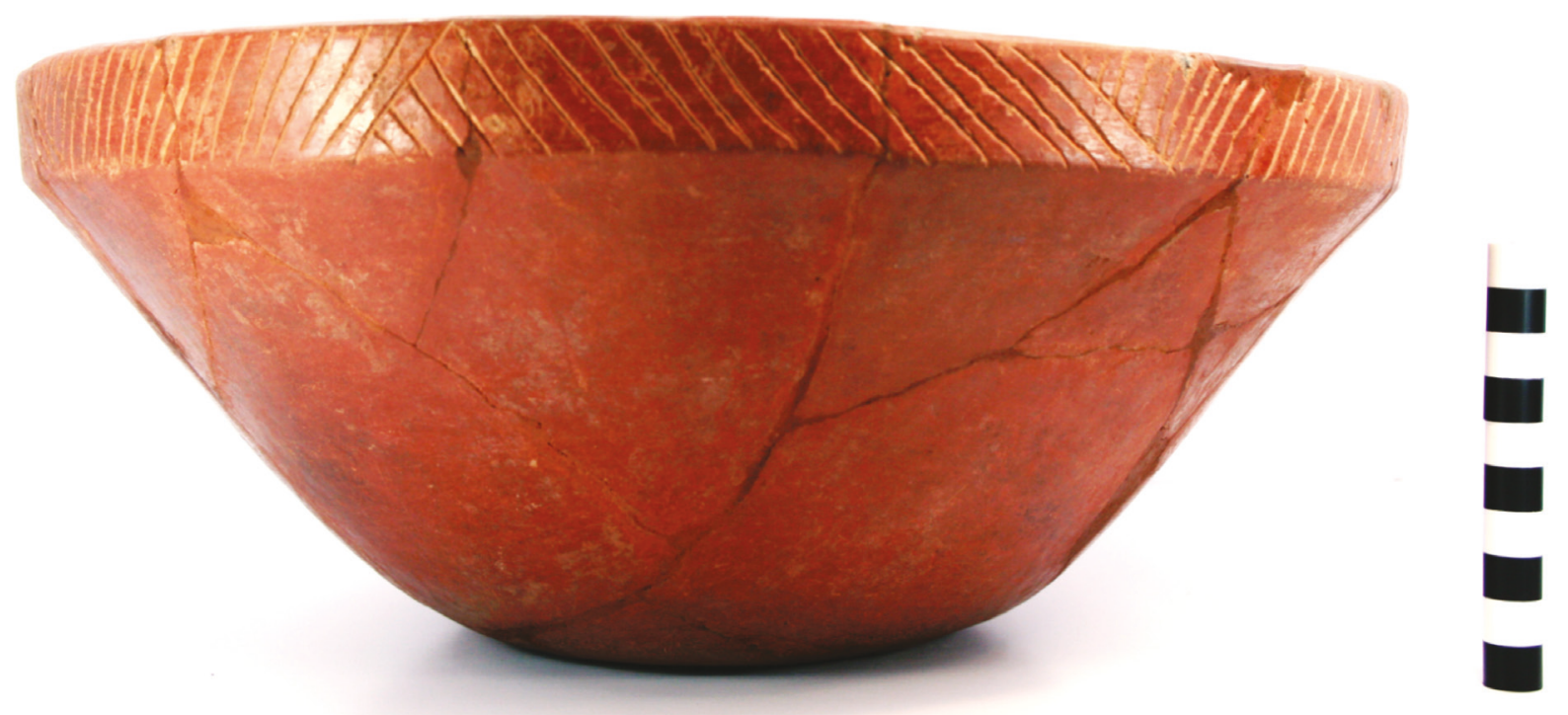

Special Publication No. 41

Friends of Northeast Texas Archaeology, Austin and Pittsburg 


\section{Friends of Northeast Texas Archaeology Editor, Timothy K. Perttula 10101 Woodhaven Dr. Austin, Texas 78753 tkp4747@aol.com \\ Friends of Northeast Texas Archaeology, Distribution, Bo Nelson, 344 CR 4154 \\ Pittsburg, Texas 75686 \\ RBoNelson@aol.com}

Cover art: Sanders Engraved carinated bowl in Burial B-4 at the T. M. Sanders site (41LR2).

Copyright 2016, Friends of Northeast Texas Archaeology (Pittsburg and Austin) 


\section{Table of Contents}

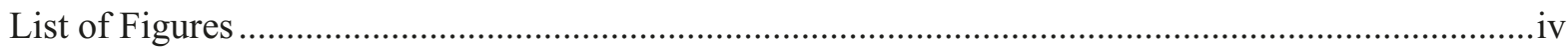

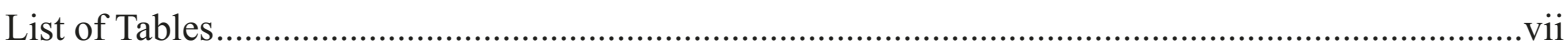

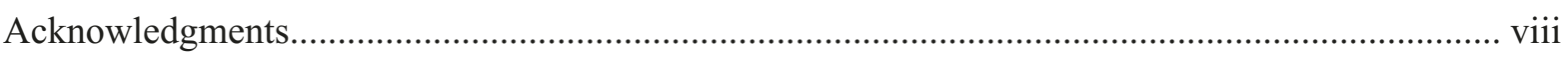

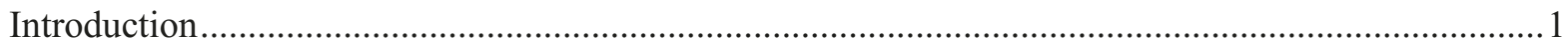



1931 Excavations in Mound No. 1 or East Mound at the T. M. Sanders Site ..................................5

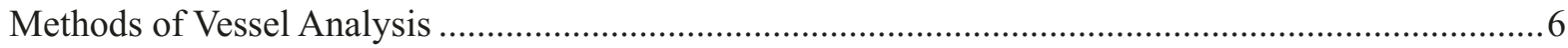

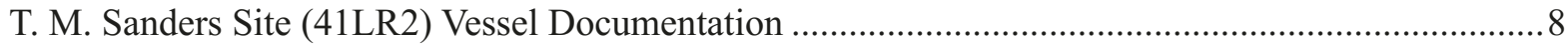

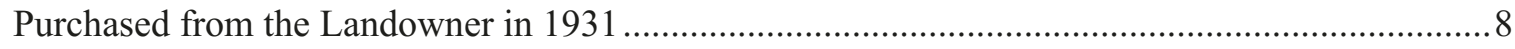

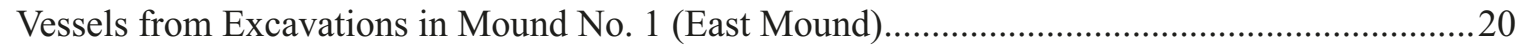

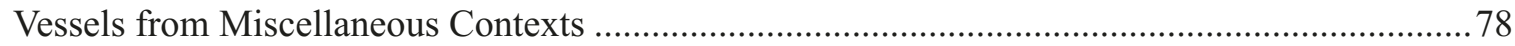

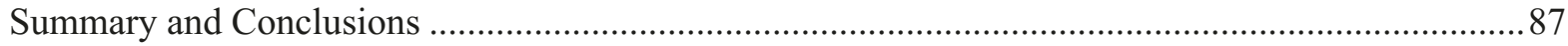

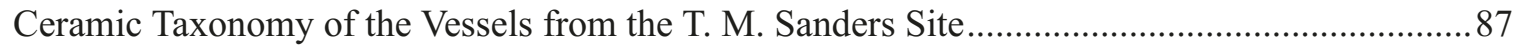

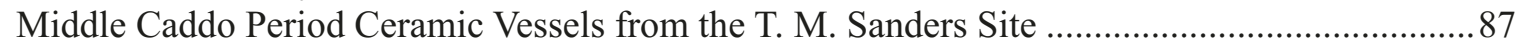

Historic Caddo Period Ceramic Vessels from the T. M. Sanders Site ............................................91

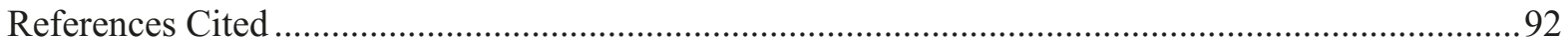




\section{List of Figures}

Figure 2. Looking north at Mound No. 1 (right) and Mound No. 2 (left) in November 2013...............2

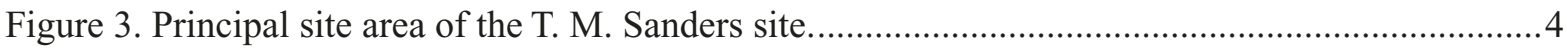

Figure 4. Map of Mound No. 1 at the T. M. Sanders site, showing burials

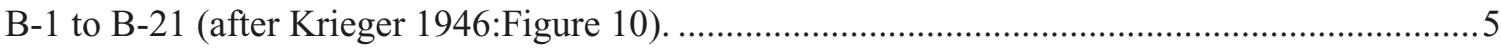

Figure 5. Sanders Engraved neckless bottle from the T. M. Sanders site (41LR2)..............................

Figure 6. Sanders Engraved neckless bottle from the T. M. Sanders site (41LR2)............................. 10

Figure 7. Bois d'Arc Plain bowl from the T. M. Sanders site (41LR2)............................................11

Figure 8. Bois d'Arc Plain bowl from the T. M. Sanders site (41LR2)............................................. 12

Figure 9. Bois d'Arc Plain bowl from the T. M. Sanders site (41LR2) ............................................ 13

Figure 10. Maxey Noded Redware bottle from the T. M. Sanders site (41LR2). ............................... 14

Figure 11. Maxey Noded Redware bottle from the T. M. Sanders site (41LR2). ................................. 15

Figure 12. Maxey Noded Redware bottle from the T. M. Sanders site (41LR2). ............................... 16

Figure 13. Bois d'Arc Plain jar from the T. M. Sanders site (41LR2) ............................................... 17

Figure 14. Bois d'Arc Plain bowl from the T. M. Sanders site ......................................................... 18

Figure 15. East Incised bowl from the T. M. Sanders site (41LR2) ................................................ 19

Figure 16. Sanders Engraved carinated bowl in Burial B-1 at the T. M. Sanders site (41LR2)...........20

Figure 17. Maxey Noded Redware bottle in Burial B-1 at the T. M. Sanders site (41LR2)................21

Figure 18. Maxey Noded Redware bottle in Burial B-2 at the T. M. Sanders site (41LR2)...............22

Figure 19. Bois d'Arc Plain bowl in Burial B-3 at the T. M. Sanders site (41LR2)..........................23

Figure 20. Sanders Engraved carinated bowl in Burial B-4 at the T. M. Sanders site (41LR2)...........24

Figure 21. Bois d'Arc Plain bottle in Burial B-4 at the T. M. Sanders site (41LR2)..........................25

Figure 22. Bois d'Arc Plain bottle in Burial B-5 at the T. M. Sanders site (41LR2).........................26

Figure 23. Incised jar in Burial B-5 at the T. M. Sanders site (41LR2) ...........................................27

Figure 24. Bois d'Arc Plain bottle in Burial B-5 at the T. M. Sanders site (41LR2)..........................28

Figure 26. Maxey Noded Redware bottle in Burial B-5 at the T. M. Sanders site (41LR2)................30

Figure 27. Appliqued jar in Burial B-5 at the T. M. Sanders site (41LR2)........................................ 31

Figure 29. Engraved carinated bowl in Burial B-6 at the T. M. Sanders site (41LR2)........................33

Figure 30. Sanders Incised bowl in Burial B-6 at the T. M. Sanders site (41LR2).............................. 34

Figure 32. Sanders Slipped bowl in Burial B-9 at the T. M. Sanders site (41LR2)............................ 36

Figure 33. Sanders Engraved jar in Burial B-9 at the T. M. Sanders site (41LR2):



Figure 34. Sanders Engraved carinated bowl in Burial B-9 at the T. M. Sanders site (41LR2)............38

Figure 35. Bois d'Arc Plain, var. Crawford bowl in Burial B-9 at the T. M. Sanders site (41LR2).....39

Figure 36. Maxey Noded Redware bottle in Burial B-9 at the T. M. Sanders site (41LR2)...............40

Figure 37. Canton Incised jar in Burial B-9 at the T. M. Sanders site (41LR2)..................................41

Figure 38. Bois d'Arc Plain bowl in Burial B-9 at the T. M. Sanders site (41LR2)..........................42 
Figure 39. Sanders Engraved carinated bowl in Burial B-11 at the T. M. Sanders site (41LR2).........43

Figure 40. Bois d'Arc Plain carinated bowl in Burial B-11 at the T. M. Sanders site (41LR2). .........44

Figure 41. Appliqued olla in Burial B-11 at the T. M. Sanders site .................................................45

Figure 42. Bois d'Arc Plain, var. Crawford carinated bowl in Burial B-11 at the

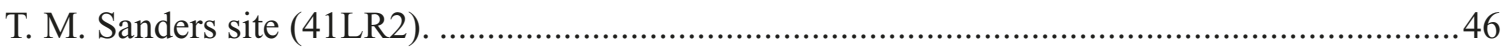

Figure 43. Maxey Noded Redware tri-lobed bottle in Burial B-12 at the

T. M. Sanders site (41LR2).

Figure 44. Bois d'Arc Plain, var. Crawford bowl in Burial B-12 at the

T. M. Sanders site (41LR2). .48

Figure 46. cf. Monkstown Fingernail Impressed jar in Burial B-12 at the

T. M. Sanders site (41LR2). .50

Figure 47. Sanders Incised carinated bowl in Burial B-12 at the T. M. Sanders site (41LR2)............51

Figure 48. Appliqued bottle in Burial B-12 at the T. M. Sanders site (41LR2).................................52

Figure 49. Maxey Noded Redware bottle in Burial B-13 at the T. M. Sanders site (41LR2)..............53

Figure 50. Maxey Noded Redware bottle in Burial B-13 at the T. M. Sanders site (41LR2)..............54

Figure 51. Canton Incised jar in Burial B-13 at the T. M. Sanders site (41LR2)...............................55

Figure 52. Bois d'Arc Plain bowl in Burial B-15 at the T. M. Sanders site (41LR2).........................56

Figure 53. Bois d'Arc Plain bowl in Burial B-15 at the T. M. Sanders site (41LR2).........................57

Figure 54. Red-painted cf. Angel Negative Painted conjoined bottle-jar in Burial B-15

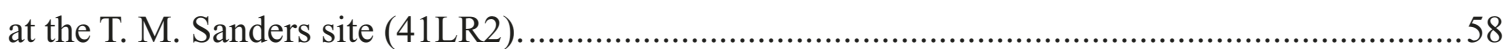

Figure 55. Maxey Noded Redware bottle in Burial B-15 at the T. M. Sanders site (41LR2).............59

Figure 56. Bois d'Arc Plain carinated bowl in Burial B-15 at the T. M. Sanders site (41LR2). ..........60

Figure 57. Sanders Engraved bowl in Burial B-16 at the T. M. Sanders site (41LR2).......................61

Figure 58. Sanders Slipped bowl in Burial B-16 at the T. M. Sanders site (41LR2).........................62

Figure 59. Sanders Slipped bottle in Burial B-17 at the T. N. Sanders site (41LR2)...........................63

Figure 60. Bois d'Arc Plain jar in Burial B-17 at the T. M. Sanders site (41LR2).............................64

Figure 61. Hickory Engraved bowl in Burial B-17 at the T. M. Sanders site (41LR2).......................65

Figure 62. Monkstown Fingernail Impressed jar in Burial B-17 at the T. M. Sanders site (41LR2)...66

Figure 63. Plain shell-tempered jar in Burial B-17 at the T. M. Sanders site (41LR2):

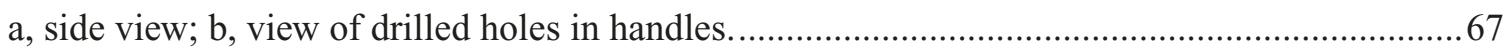

Figure 64. Sanders Engraved jar in Burial B-17 at the T. M. Sanders site (41LR2)............................68

Figure 65. Monkstown Fingernail Impressed jar from the T. M. Sanders site....................................69

Figure 66. Haley Engraved bottle from the T. M. Sanders site (41LR2). ......................................... 70

Figure 67. Sanders Slipped bowl in Burial B-20 at the T. M. Sanders site (41LR2) ..........................71

Figure 68. Sanders Engraved carinated bowl in Burial B-20 at the T. M. Sanders site (41LR2)..........72

Figure 69. Sanders Engraved neckless bottle in Burial B-20 at the T. M. Sanders site (41LR2). ........73

Figure 70. Bois d'Arc Plain carinated bowl in Burial B-20 at the

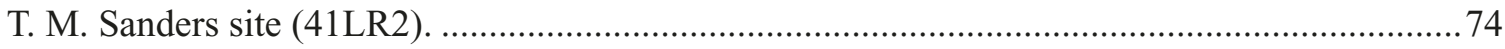


Figure 71. Bois d'Arc Plain carinated bowl in Burial B-20 at the T. M. Sanders site (41LR2). ..........75

Figure 72. Bois d'Arc Plain carinated bowl in Burial B-20 at the T. M. Sanders site (41LR2). ..........76

Figure 73. Bois d'Arc Plain bowl in Burial B-21 at the T. M. Sanders site (41LR2)..........................77

Figure 74. Simms Engraved, var. Darco carinated bowl from midden excavations

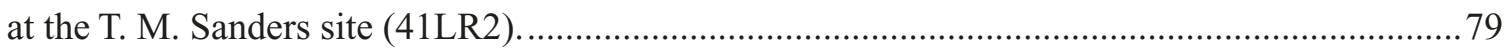

Figure 75. Sanders Engraved bowl in disturbed burial at the T. M. Sanders site (41LR2).................81

Figure 76. Monkstown Fingernail Impressed jar from the T. M. Sanders site (41LR2)......................82

Figure 77. Maxey Noded Redware bottle from the T. M. Sanders site (41LR2). ...............................83

Figure 78. Sanders Engraved carinated bowl from midden excavations at the

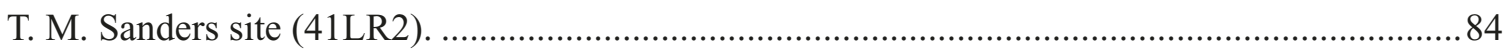

Figure 79. Sanders Engraved carinated bowl from the T. M. Sanders site (41LR2).......................... 85

Figure 80. Emory Punctated jar from midden excavations at the T. M. Sanders site (41LR2).............86 


\section{List of Tables}

Table 1. Burial Features at the T. M. Sanders site (based on Jackson 2000).....................................6

Table 2. Ceramic types in the Middle Caddo period component at the T. M. Sanders site..................8 88

Table 3. Vessel forms represented in the defined ceramic types in the Middle Caddo

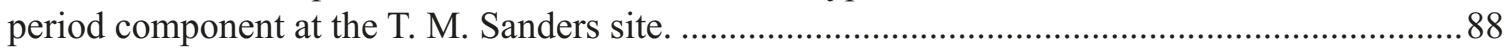

Table 4. Different tempers represented in the defined ceramic types in the Middle Caddo period component at the T. M. Sanders site.

Table 5. Estimated volume (in liters) of vessel forms in the Middle Caddo

period component at the T. M. Sanders site. 


\section{Acknowledgments}

I appreciate the access provided by the Caddo Nation of Oklahoma and the staff at the Texas Archeological Research Laboratory at The University of Texas at Austin, in particular Marybeth Tomka, to the records and vessel collections from the Sanders site. Bo Nelson took the excellent vessel photographs, and Sandy Hannum and Lance Trask prepared other figures and maps included in this monograph. 


\section{Introduction}

The T. M. Sanders site (41LR2) is one of the more important ancestral Caddo sites known in East Texas (Figure 1), primarily because of its two earthen mounds (Figure 2) and the well-preserved mortuary features of Caddo elite persons buried in Mound No. 1 (the East Mound). The Sanders site is located on a broad alluvial terrace just south of the confluence of Bois d'Arc Creek and the Red River. The terrace has silt loam soils, which have a shallow dark brown silt loam A-horizon overlying thick B- and C-horizons that range from dark reddish-brown, reddish-brown, dark brown, to yellowish-red in color. These soils formed in loamy alluvial sediments of the Red River.

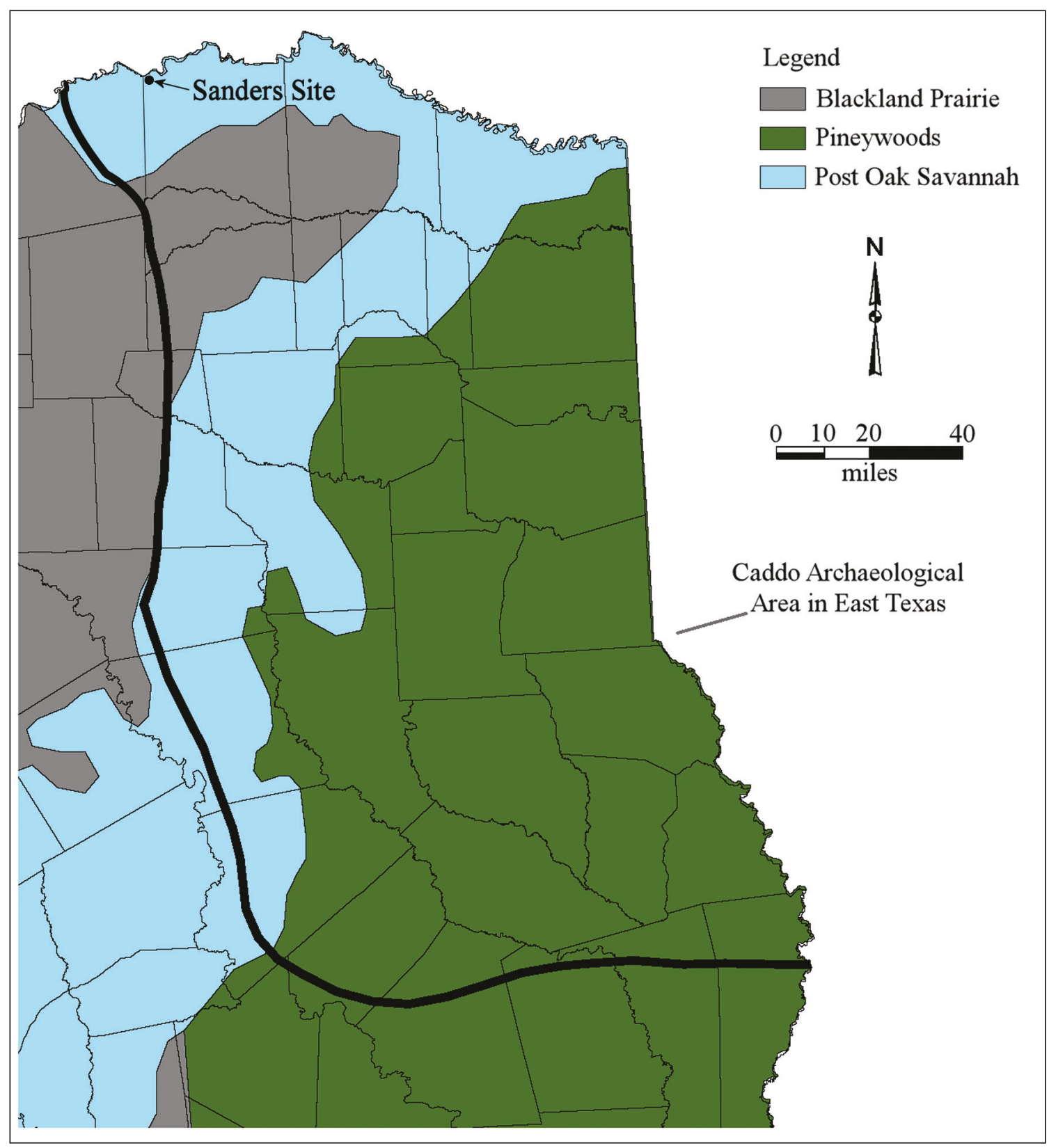

Figure 1. The location of the T. M. Sanders site (41LR2) in Lamar County in East Texas. 


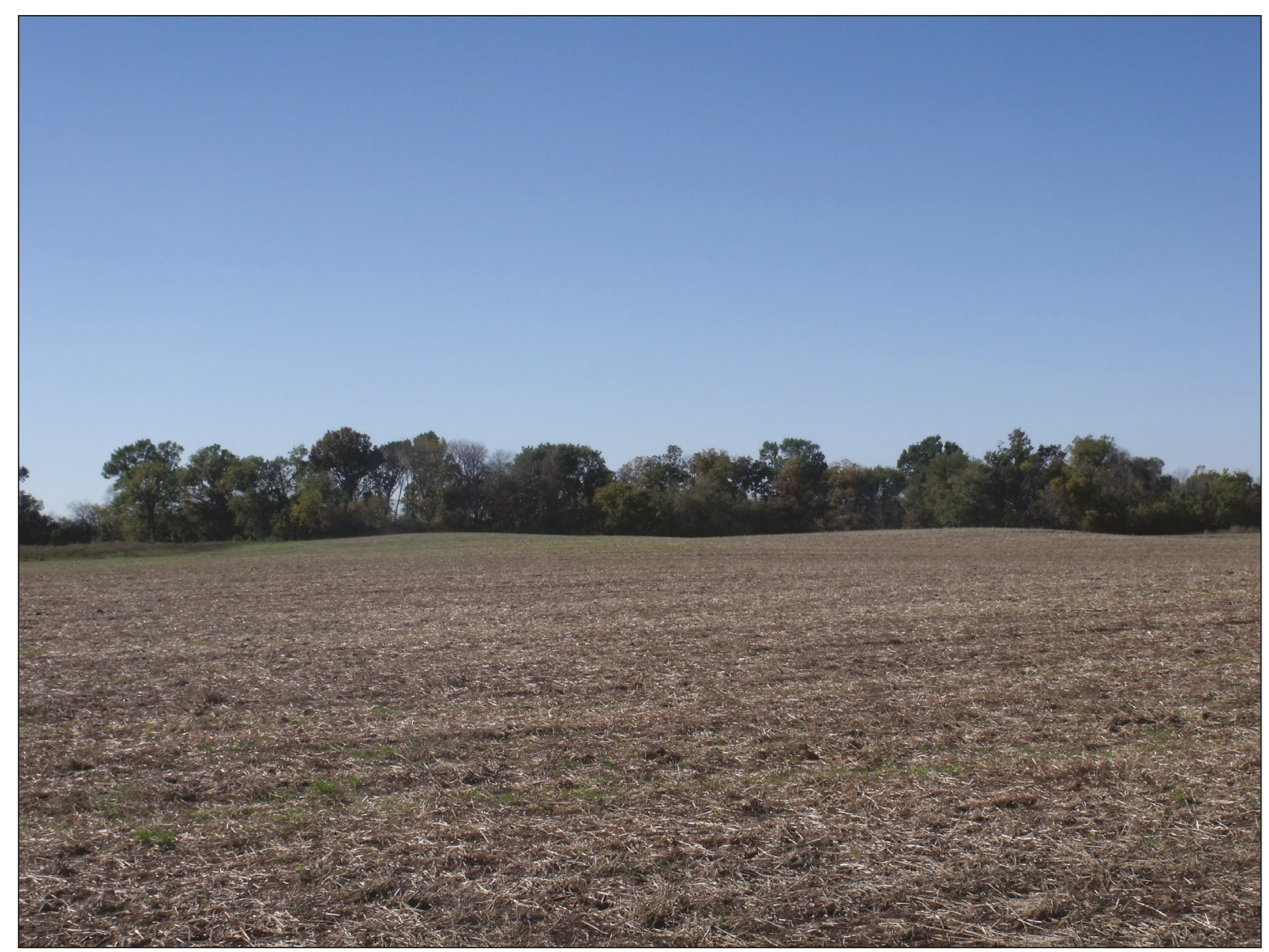

Figure 2. Looking north at Mound No. 1 (right) and Mound No. 2 (left) in November 2013.

In this Special Publication, we discuss the analysis and documentation of the 78 ceramic vessels from the T. M. Sanders site in the collections of the Texas Archeological Research Laboratory at The University of Texas at Austin. Our concern is in documenting the stylistic and technological character of these vessels, and assessing their cultural relationships and stylistic associations; almost 80 percent of these vessels are from burial features excavated by University of Texas archaeologists in Mound No. 1 (East Mound) in July and August 1931 (Jackson et al. 2000); others are from excavations in midden deposits between the two mounds (see Krieger 1946:Figure 9). We also consider and revise the current ceramic taxonomy for a number of the vessels from the T. M. Sanders site. 


\section{Archaeological Context}

Archaeological work began at the site in 1931 by The University of Texas at Austin (Chelf 1939; Jackson et al. 2000; Pearce and Jackson 1931), with sporadic work by members of the Dallas Archeological Society in the 1940s and 1950s (Hanna 1950; Harris 1953; Housewright 1940; Wilson 1948; Wilson and Housewright 1941). Archaeological and bioarchaeological interpretations of the findings from this work at the T. M. Sanders site began with Krieger's analyses $(1946,2000,2009)$ of the burial features and associated funerary objects (including marine shell gorgets, shell beads, arrow points, and ceramic vessels). These analyses and studies continue to the present day, and rely upon the reanalysis and reinterpretation of the archaeological (Bruseth et al. 1995; Hamilton 1997; Jurney and Young 1995; Perttula 1997, 2013; Schambach 1995, 1999, 2000a, 2000b) and bioarchaeological (Maples 1962; Wilson 1993, 1994, 1995, 1997; Wilson and Cargill 1993; Wilson and Derrick 1996) materials recovered in the Pearce and Jackson (1931) and Jackson et al. (2000) work. Most recently, Perttula et al. (2015) and Perttula and Nelson (2016) have reported on the findings from extensive surface collections in 30+ artifact clusters across the T. M. Sanders site. Geophysical investigations were also conducted on a 20 acre area in the eastern part of the site, east of Mound No. 1, in December 2014 by Dr. Chester P. Walker but the findings of that work have not been prepared for publication as of this writing.

Although the T. M. Sanders site is not dated by radiocarbon analyses, the general consensus is that the main Caddo occupation took place around ca. A.D. 1100-1300 (see Bruseth 1998), contemporaneous with related sites downstream along the Red River near its confluence with the Kiamichi River, and other sites in the upper Sabine River basin (see Krieger 1946, 2009) that are considered to be Middle Caddo period in age. At this point, and in the absence of radiocarbon dates from any features or archaeological deposits at the site, it is just as likely that the main component at the T. M. Sanders site dates from ca. A.D. 1200-1400, the generally accepted age range for the period (Perttula 2012:Table 1-1).

A late $17^{\text {th }}$-early $18^{\text {th }}$ century Caddo occupation is also present at the T. M. Sanders site, but remains poorly known (e.g., Bell et al. 1967:Figure 1; Harris et al. 1965:288; Harris and Harris 1967:131). Harris and Harris (1967:131) commented that European "trade material is exceptionally scarce" at the T. M. Sanders site, but they do note that 478 glass beads had been found at the site. Harris (1953:20) had previously stated that several Caddo burials with European trade goods had been found along Bois d'Arc Creek south of Mound No. 2, the larger or West Mound (see Figure 2).

Archaeological survey investigations conducted in 2014 indicate that there are archaeological deposits on the alluvial terrace of the Red River that sits at 450 feet amsl. These deposits are distributed both south and east of the East and West Mounds, extending approximately $1260 \mathrm{~m}$ east from the East Mound and approximately $960 \mathrm{~m}$ south of the West Mound (Figure 3), an area of approximately 300 acres, with distinctive clusters of surface collected artifacts beginning close to both mounds. This extensive distribution of artifacts indicates that there is an extensive ancestral Caddo settlement at the site, not just two earthen mounds and a midden area between them (see Krieger 1946:Figure 9).

There is a small secondary area of the T. M. Sanders site on a higher alluvial terrace (474 ft. amsl) that overlooks the principal site area (see Perttula and Marceaux 2011; Peyton 2013) (see Figure 3). Ancestral Caddo ceramic sherds and other artifacts occur in low densities on this landform. 


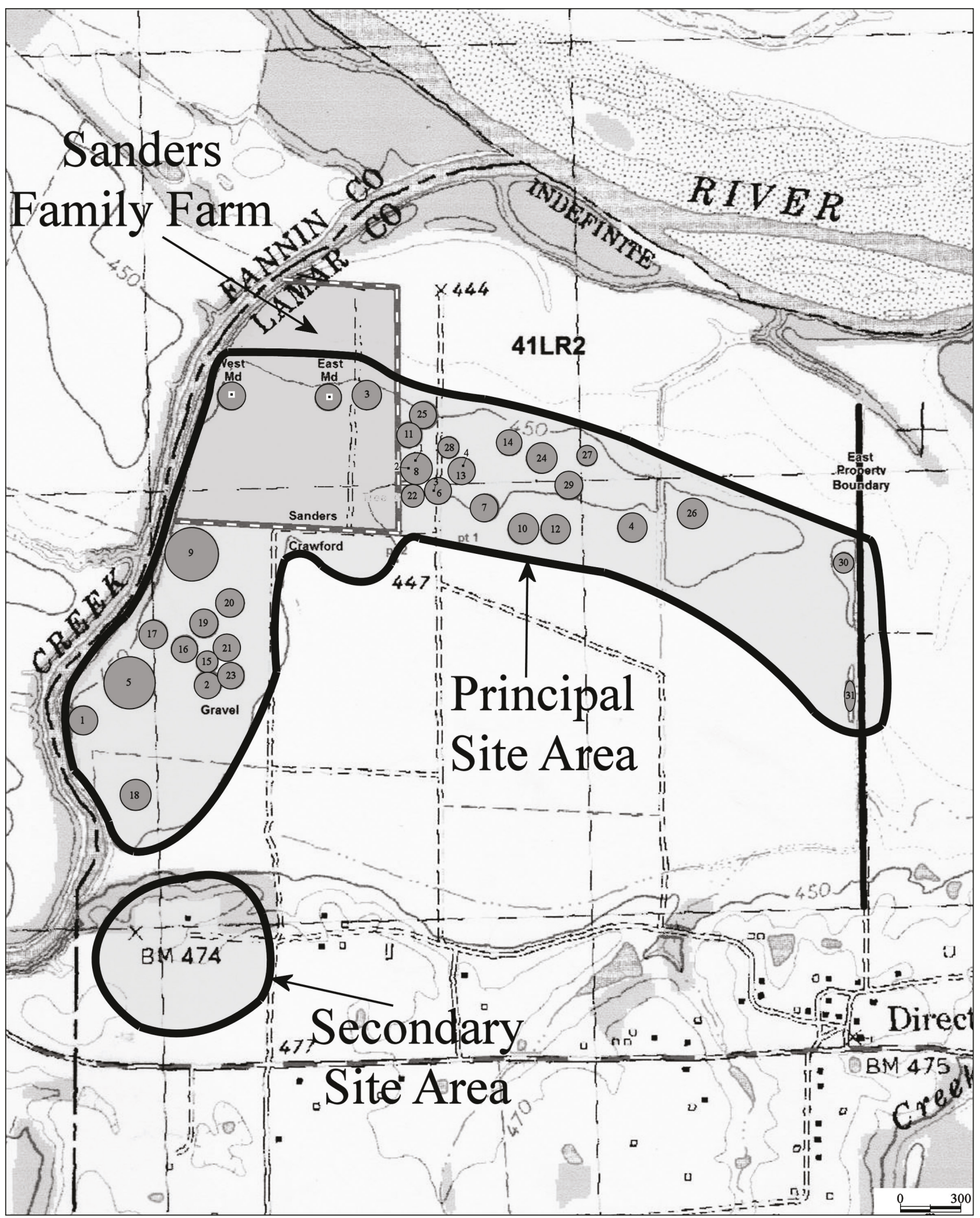

Figure 3. Principal site area of the T. M. Sanders site. 


\section{Excavations in Mound No. 1 or the East Mound at the T. M. Sanders Site}

Excavations in Mound No. 1 or the East Mound at the T. M. Sanders site uncovered 21 burial features, 12 graves with a single individual and the other nine burials with multiple individuals (a total of 48 individuals), from three to eight people in these burial features (Figure 4 and Table 1). About 76 percent of the burials had ceramic vessel funerary offerings, with a range of 1-8 vessels per burial feature.

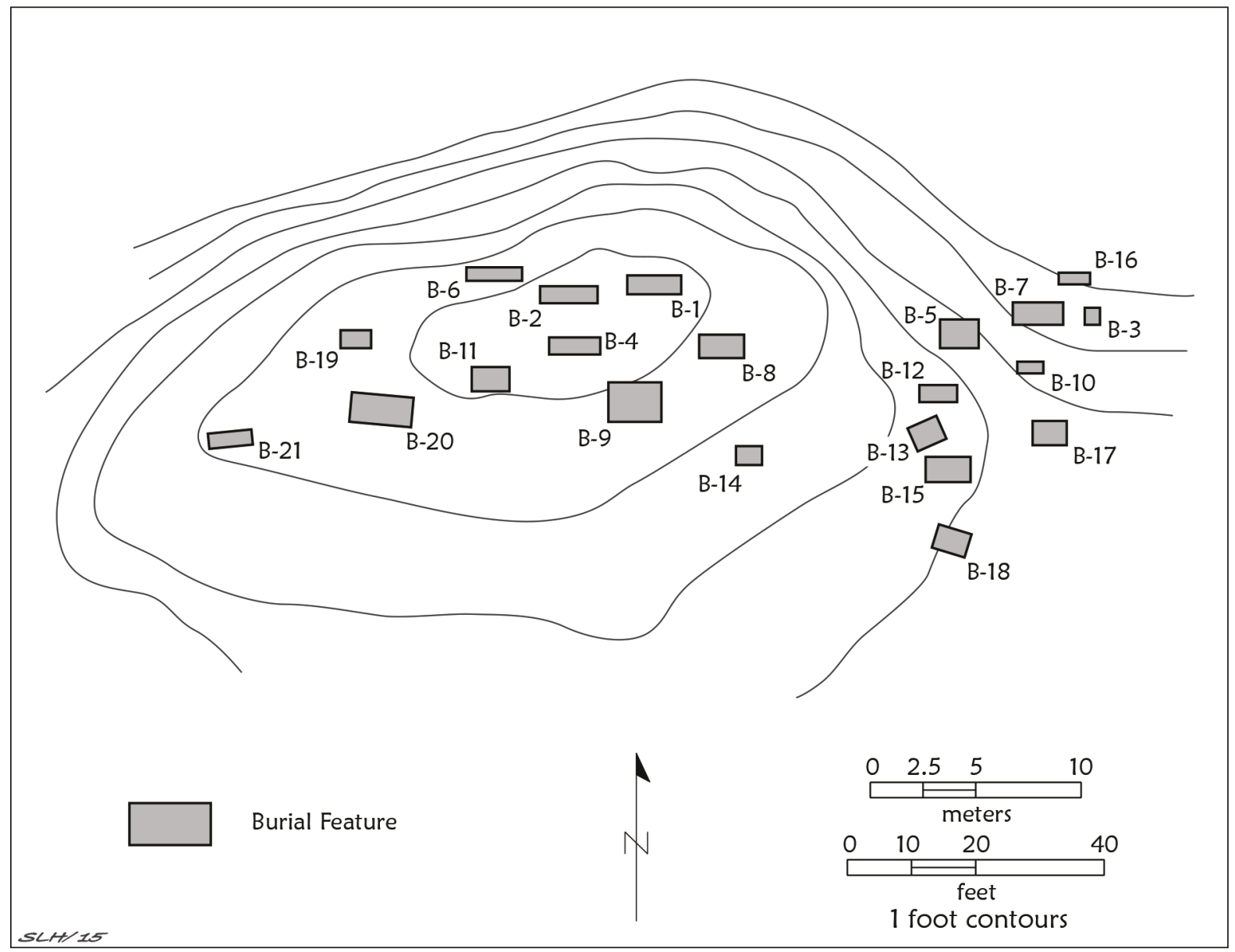

Figure 4. Map of Mound No. 1 at the T. M. Sanders site, showing burials B-1 to B-21 (after Krieger 1946:Figure 10).

Table 1. Burial Features at the T. M. Sanders site (based on Jackson 2000).

\begin{tabular}{llll}
\hline Burial No. No. of Individuals & $\begin{array}{l}\text { No. of Ceramic } \\
\text { Vessels }\end{array}$ & Other Funerary Offerings \\
\hline
\end{tabular}

1

2

3

\section{2}

1

1
Shell gorget; stone pipe; stone drills; shell beads Ceramic pipe; shell gorget; shell beads; arrow point; shell pendant Shell gorget 
Table 1. Burial Features at the T. M. Sanders site (based on Jackson 2000), cont.

\begin{tabular}{|c|c|c|c|}
\hline Burial No. & No. of Individuals & $\begin{array}{l}\text { No. of Ceramic } \\
\text { Vessels }\end{array}$ & Other Funerary Offerings \\
\hline 4 & 1 & 2 & $\begin{array}{l}\text { Ceramic pipe; arrow points; } \\
\text { shell gorget; shell beads; } \\
\text { shell discs }\end{array}$ \\
\hline 5 & 7 & 5 & $\begin{array}{l}\text { Shell gorget; stone pipe; } \\
\text { arrow points }\end{array}$ \\
\hline 6 & 1 & 3 & $\begin{array}{l}\text { Ceramic pipe; shell pendants; } \\
\text { shell beads; conch shell } \\
\text { beads; bone awls }\end{array}$ \\
\hline 7 & 5 & - & conch shell beads \\
\hline 8 & 1 & 1 & $\begin{array}{l}\text { Ceramic pipe; shell gorgets; } \\
\text { conch shell dipper; shell } \\
\text { beads }\end{array}$ \\
\hline 9 & 1 & 7 & $\begin{array}{l}\text { Bone awls; conch shell; shell } \\
\text { gorget }\end{array}$ \\
\hline 10 & 1 & - & - \\
\hline 11 & 1 & 4 & Conch shell beads \\
\hline 12 & 5 & 6 & $\begin{array}{l}\text { Celt; arrow point; shell } \\
\text { gorgets; conch beads; shell } \\
\text { beads }\end{array}$ \\
\hline 13 & 6 & 4 & Shell beads; shell gorget \\
\hline 14 & 1 & - & arrow points; shell discs \\
\hline 15 & 6 & 6 & $\begin{array}{l}\text { Conch shell beads; bone } \\
\text { needle }\end{array}$ \\
\hline 16 & 1 & 2 & - \\
\hline 17 & 8 & 8 & $\begin{array}{l}\text { Shell gorget; stone scraper; } \\
\text { ceramic pipe; conch shell } \\
\text { beads; bone needle }\end{array}$ \\
\hline 18 & 4 & - & Paint stone \\
\hline 19 & 1 & - & $\begin{array}{l}\text { Shell gorgets; arrow point; } \\
\text { shell beads }\end{array}$ \\
\hline 20 & 4 & 7 & $\begin{array}{l}\text { Shell gorget; stone ear plugs; } \\
\text { scapula hoe; conch shell } \\
\text { beads; conch shell discs; shell } \\
\text { pendants }\end{array}$ \\
\hline 21 & 3 & 2 & conch shell beads \\
\hline
\end{tabular}

The burials with multiple individuals contain more ceramic vessels (a mean of 4.2 vessels per burial feature) than do the burials with single individuals (a mean of 1.9 vessels per burial feature) (see Table 1). The burial features with the greatest number of ceramic vessels are situated either on the crest of the mound (Burials B-9 and B-20) or along the eastern edge of the mound (Burials B-5, B-12, B-15, and B-17) (see Figure 4). Krieger (1946:185) has noted that the ceramics from the T. M. Sanders site burial features (and midden excavations) are "remarkably uniform in shape, decoration, paste, and finish." 


\section{Methods of Vessel Analysis}

As with other ancestral Caddo ceramic vessel documentation studies recently completed of ceramic assemblages from East Texas sites (cf. Perttula et al. 2013, 2015), the following consistent set of attributes were employed in the study and documentation of the ceramic vessels from the T. M. Sanders site:

Non-plastics: Deliberate and indeterminate materials in the paste (Rice 1987:411), including a variety of tempers (i.e., grog or crushed sherds, bone, hematite/ferruginous sandstone, shell, quartz sands, etc.) and "particulate matter of some size." The grog, bone, or shell appears to have been deliberately added to the paste as tempers. The bone or shell used for temper had been burned and calcined, then crushed, before it was added to the paste.

Vessel Form: Vessel form categories include open containers (bowls of several sizes, including effigy bowls, carinated bowls, and compound bowls) and restricted containers, including jars and bottles, as well as plates. As restricted containers, jars allow access by hand, but bottles do not (Brown 1996:335). Other form attributes that were recorded include the rim profile (outflaring or everted, vertical or standing, and inverted), lip profile (rolled to the exterior, rounded, flat, or thinned), and base shape (flat or rounded).

Core Colors: Observations on ceramic cross-section colors permit consideration of oxidation patterns (Teltser 1993:Figure 2A-H), and thus the conditions under which the vessel was fired and then cooled after firing. Comments are included for these attributes on the presence and location of fire-clouding, sooting or smudging from cooking use (Skibo 1992), and the preservation of any charred organic remains.

Wall Thickness: Thickness was recorded in millimeters, using a vernier caliper, at the lip, along the rim, at several points along the body, and at the base when possible (only for the vessels that were not complete).

Interior and Exterior Surface Treatment: The primary methods of finishing the surface of the vessels includes either smoothing, burnishing, and polishing (Rice 1987:138). Brushing, while a popular method of roughening the surface (particularly the body) of large and small Middle (ca. A.D. 1200-1450) and Late Caddo (ca. A.D. 1450-1680) period cooking jars in several parts of the Caddo area (Perttula 2015), is virtually absent as a decorative treatment in the T. M. Sanders site vessels, is here considered a decorative treatment rather than solely a functional surface treatment (cf. Rice 1987:138), although not all Caddo ceramic analysts treat brushing as a decorative treatment. Smoothing creates "a finer and more regular surface... [and] has a matte rather than a lustrous finish" (Rice 1987:138). Burnishing, on the other hand, creates an irregular lustrous finish marked by parallel facets left by the burnishing tool (perhaps a pebble or bone). A polished surface treatment is marked by a uniform and highly lustrous surface finish, done when the vessel is dry, but without "the pronounced parallel facets produced by burnishing leather-hard clay" (Rice 1987:138).

The application of a hematite-rich clay slip (Ferring and Perttula 1987), either red or black after firing in an oxidizing or reducing (i.e., low-oxygen) environment, is another form of surface treatment noted in many East Texas assemblage, and the frequency of red-slipped vessels at Sanders is a notable characteristic of the vessel assemblage. On these vessels, the clay slip is more frequently applied on the vessel exterior, or on both surfaces, than on the interior surface, and then was either burnished or polished after it was leather-hard or dry. 
Height and Orifice Diameter: These attributes, measured in centimeters, were recorded with a ruler.

Diameter at Bottom of Rim and Base Diameter: Also recorded in millimeters using a ruler, these attributes permit characterization of the overall contour and shape of the vessel.

Volume: With measurements of height and orifice diameter obtained from the vessels, as well as other measurements of size (i.e., base diameter and maximum body width), volumes were estimated by comparison with known vessel volumes of specific forms (i.e., carinated bowl, jar, bottle, compound bowl, and bowl) in many other recently documented Caddo vessel assemblages.

Base Diameter and Shape: these attributes were either measured in centimeters or by shape attributes: circular or square, and flat or round.

Decoration: Decorative techniques present in the vessel collection from Caddo sites in East Texas include engraving, incising, trailing, punctating, pinching, brushing, and appliquéing, and on certain vessels, combinations of decorative techniques (i.e., incised-punctated) created the decorative elements and motifs. Engraving was done with a sharp tool when the vessel was either leather-hard, or after it was fired, while the other decorative techniques were executed with tools (trailing, incising, and punctation), by adding strips of clay to the wet body (appliqué), using frayed sticks or grass stems (brushing) dragged across the body surface, or fingernails (certain forms of punctations and pinching), when the vessel was wet or still plastic. Excising is considered a form of engraved decoration, where the clay is deliberately and closely marked/scraped and carved away with a sharp tool, usually to create triangular elements, tick marks, or excised punctations.

Use of Pigments: Another form of vessel decoration is the use of red (hematite or ochre) or white (kaolin clay) clay pigments that have been smeared or rubbed into the engraved lines of certain vessels.

Type: The kinds of ceramic types and defined varieties in the collections from East Texas sites follow Suhm and Jelks (1962), Brown (1996), and for post-1962 ceramic types:

Perttula and Selden (2014).

\section{T. M. Sanders Site (41LR2) Vessel Documentation}

The analyzed vessel collection from the T. M. Sanders site at the Texas Archeological Research Laboratory totals 78 vessels. They include 11 vessels purchased from the landowner in 1931, 60 vessels from the 1931 University of Texas excavations in Mound No. 1 or the East Mound, and seven vessels from miscellaneous contexts within the site.

\section{Purchased from the Landowner in 1931}

During the plowing of Mound No. 1 at the T. M. Sanders site by the landowner, Mr. T. M. Sanders, in the early part of the $20^{\text {th }}$ century, 11 ceramic vessels were recovered from disturbed burials (Jackson 2000:9). In addition to these vessels, Mr. Sanders recovered "four shell gorgets, a pipe, earplug, celt, flint knife, conch shell, scapula hoe blade... a slate plaque, and approximately 1,300 shell beads" (Jackson 2000:9, 11). This collection was purchased by The University of Texas at Austin in 1931. 
SITE NAME OR SITE NUMBER: T. M. Sanders

VESSEL NO.: 15

VESSEL FORM: Neckless bottle with opposing suspension holes (7.0 $\mathrm{mm}$ in diameter)

NON-PLASTICS AND PASTE: grog

RIM AND LIP FORM: Inverted rim and rounded lip

CORE COLOR: $\mathrm{F}$ (fired in a reducing

environment and cooled in the open air)

INTERIOR SURFACE COLOR: brown

EXTERIOR SURFACE COLOR: brown; fire clouds on the body

WALL THICKNESS (IN MM): rim, 7.5 $\mathrm{mm}$; body, $8.0 \mathrm{~mm}$

INTERIOR SURFACE TREATMENT: none

EXTERIOR SURFACE TREATMENT: smoothed

HEIGHT (IN CM): 34.0+

ORIFICE DIAMETER (IN CM): 8.0

DIAMETER AT BOTTOM OF RIM OR NECK (IN CM): N/A

BASE DIAMETER (IN CM) AND SHAPE OF BASE: 17.0;

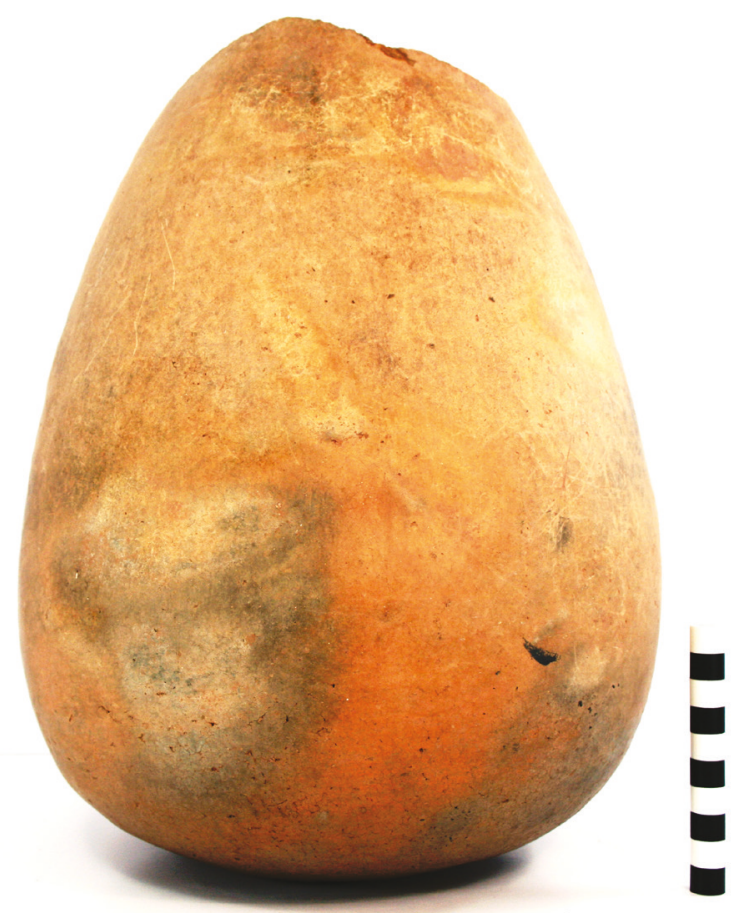

Figure 5. Sanders Engraved neckless bottle from the T. M. Sanders site (41LR2).

circular and rounded

ESTIMATED VOLUME (IN LITERS): $2.3+$

DECORATION (INCLUDING MOTIF AND ELEMENTS WHEN APPARENT): The rim portion of the bottle has a series of large cross-hatched engraved triangles. Although the entire rim is not present, it is likely that there were four engraved triangles around the rim. The remainder of the vessel is plain (Figure 5).

PIGMENT USE AND LOCATION ON VESSEL: none

TYPE AND VARIETY (IF KNOWN): Sanders Engraved 
SITE NAME OR SITE NUMBER: T. M. Sanders

VESSEL NO.: 16

VESSEL FORM: Neckless bottle with opposed suspension holes (6.7 $\mathrm{mm}$ in diameter)

NON-PLASTICS AND PASTE: grog and bone

RIM AND LIP FORM: N/A (missing)

CORE COLOR: $\mathrm{G}$ (fired in a reducing environment and cooled in the open air)

INTERIOR SURFACE COLOR: very dark grayish-brown

EXTERIOR SURFACE COLOR: yellowishbrown; fire clouds on the body and base

WALL THICKNESS (IN MM): upper body, $7.0 \mathrm{~mm}$

INTERIOR SURFACE TREATMENT: none

EXTERIOR SURFACE TREATMENT: burnished

HEIGHT (IN CM): 34.0+

ORIFICE DIAMETER (IN CM): 10.5

DIAMETER AT BOTTOM OF RIM OR NECK (IN CM): N/A

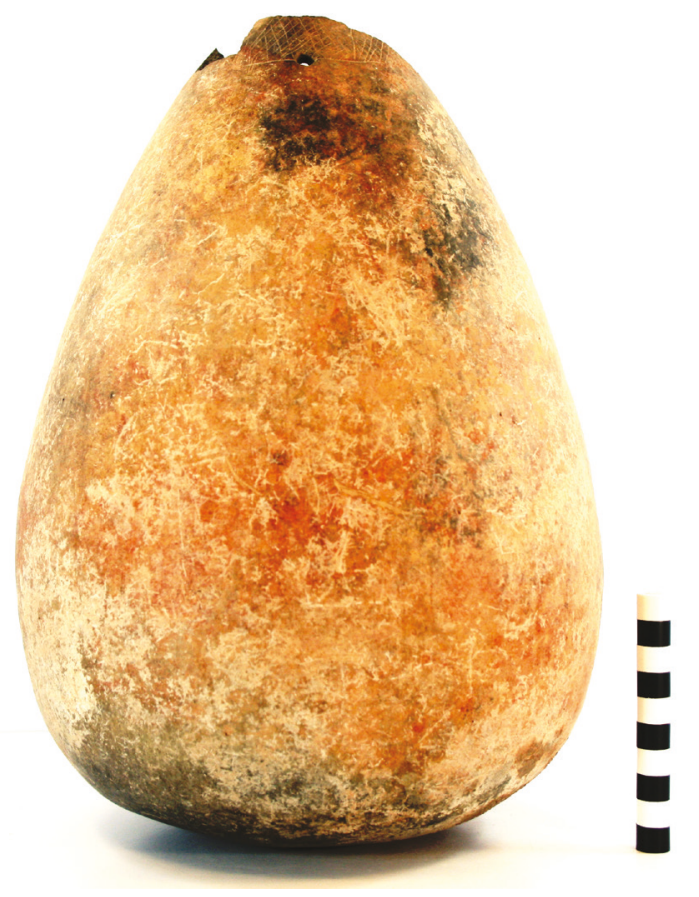

Figure 6. Sanders Engraved neckless bottle from the T. M. Sanders site (41LR2).

BASE DIAMETER (IN CM) AND SHAPE OF BASE: 11.5; circular and rounded

ESTIMATED VOLUME (IN LITERS): 1.6+

DECORATION (INCLUDING MOTIF AND ELEMENTS WHEN APPARENT): The upper vessel body has an unknown number of large cross-hatched engraved triangles pendant from a single horizontal engraved line encircling the vessel (Figure 6). One of the suspension holes was drilled through the lower part of one of the engraved pendant triangles.

PIGMENT USE AND LOCATION ON VESSEL: none

TYPE AND VARIETY (IF KNOWN): Sanders Engraved 
SITE NAME OR SITE NUMBER: T. M. Sanders

VESSEL NO.: 18

VESSEL FORM: Bowl with one or two rim peaks or lip tabs (Figure 7)

NON-PLASTICS AND PASTE: grog and bone

RIM AND LIP FORM: Direct rim and rounded lip

CORE COLOR: $\mathrm{F}$ (fired in a reducing environment and cooled in the open air)

INTERIOR SURFACE COLOR: dark yellowish-brown; fire clouds on the rim, body, and base

EXTERIOR SURFACE COLOR: dark yellowish-brown; fire clouds on the body and base

WALL THICKNESS (IN MM): rim, $6.0 \mathrm{~mm}$

INTERIOR SURFACE

TREATMENT: smoothed

EXTERIOR SURFACE

TREATMENT: smoothed

HEIGHT (IN CM): 8.5

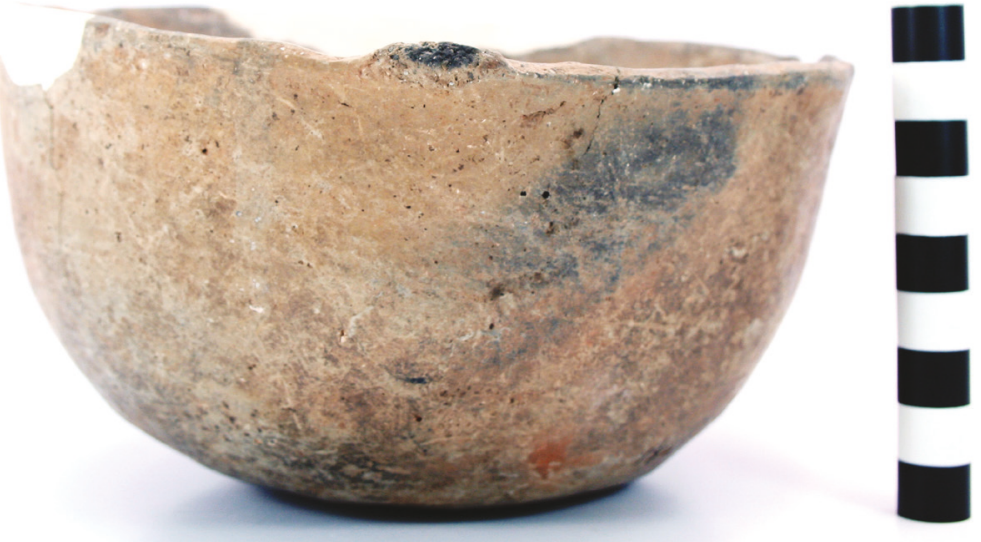

Figure 7. Bois d'Arc Plain bowl from the T. M. Sanders site (41LR2).

ORIFICE DIAMETER (IN CM): 16.8

DIAMETER AT BOTTOM OF RIM OR NECK (IN CM): N/A

BASE DIAMETER (IN CM) AND SHAPE OF BASE: 9.0; circular and rounded

ESTIMATED VOLUME (IN LITERS): 0.57

DECORATION (INCLUDING MOTIF AND ELEMENTS WHEN APPARENT): Plain (Figure 7)

PIGMENT USE AND LOCATION ON VESSEL: none

TYPE AND VARIETY (IF KNOWN): Bois d'Arc Plain 
SITE NAME OR SITE NUMBER: T. M. Sanders

VESSEL NO.: 19

VESSEL FORM: Bowl with opposed rim peaks (Figure 8)

NON-PLASTICS AND PASTE: grog

RIM AND LIP FORM: Direct rim and rounded lip

CORE COLOR: B (fired and cooled in a reducing environment)

INTERIOR SURFACE COLOR: grayish-brown; fire clouds on the body

EXTERIOR SURFACE COLOR: grayish-brown; fire clouds on the base

WALL THICKNESS (IN MM):

rim, $6.4 \mathrm{~mm}$; body, $6.5 \mathrm{~mm}$;

base, $6.8 \mathrm{~mm}$

INTERIOR SURFACE

TREATMENT: smoothed

EXTERIOR SURFACE

TREATMENT: smoothed

HEIGHT (IN CM): 7.8

ORIFICE DIAMETER (IN CM):

10.2

DIAMETER AT BOTTOM OF

RIM OR NECK (IN CM): N/A

BASE DIAMETER (IN CM)

AND SHAPE OF BASE: 9.0;

circular and flat

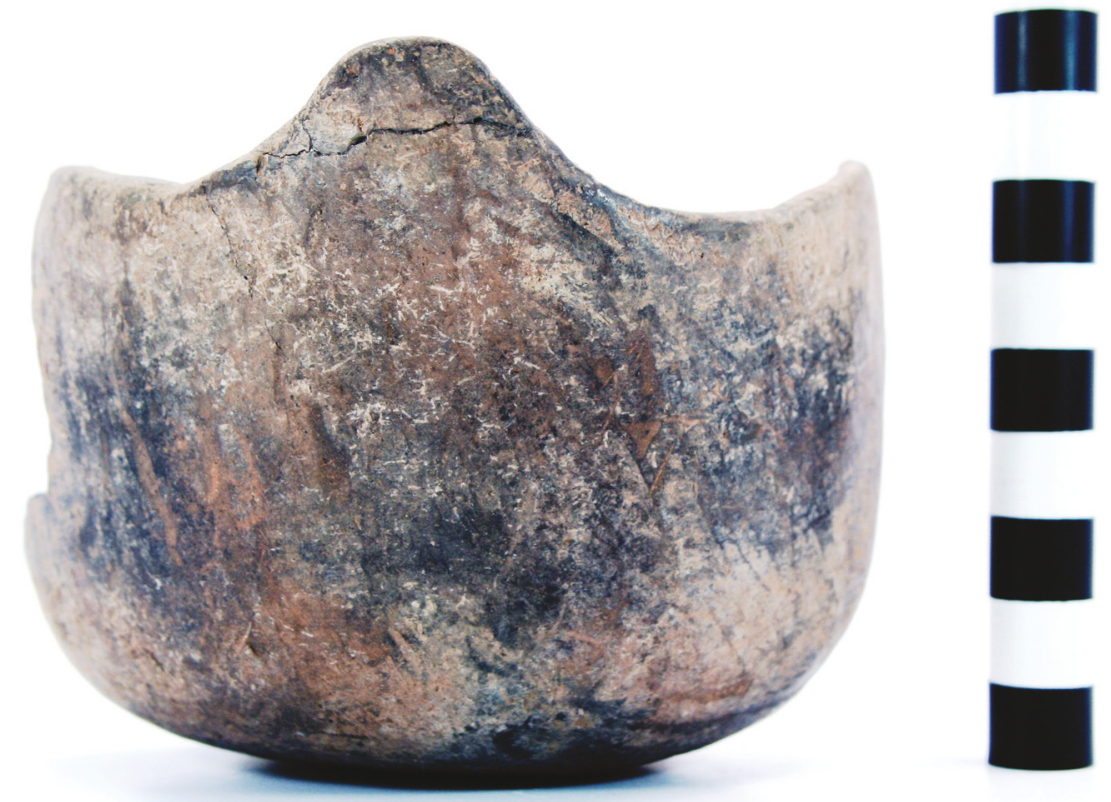

Figure 8. Bois d'Arc Plain bowl from the T. M. Sanders site

ESTIMATED VOLUME

(41LR2).

(IN LITERS): 0.32

DECORATION (INCLUDING MOTIF AND ELEMENTS WHEN APPARENT): Plain (Figure 8)

PIGMENT USE AND LOCATION ON VESSEL: none

TYPE AND VARIETY (IF KNOWN): Bois d'Arc Plain 
SITE NAME OR SITE NUMBER: T. M. Sanders

VESSEL NO.: 20

VESSEL FORM: Bowl with opposed rim peaks (Figure 9)

NON-PLASTICS AND PASTE: grog

RIM AND LIP FORM: Inverted rim and rounded lip

CORE COLOR: B (fired and cooled in a reducing environment)

INTERIOR SURFACE COLOR: dark grayish-brown

EXTERIOR SURFACE COLOR: grayish-brown; fire clouds on the rim, body, and base

WALL THICKNESS (IN MM): rim, $5.2 \mathrm{~mm}$

INTERIOR SURFACE TREATMENT: none

EXTERIOR SURFACE TREATMENT:

smoothed

HEIGHT (IN CM): 5.2

ORIFICE DIAMETER (IN CM): 5.5

DIAMETER AT BOTTOM OF RIM OR

NECK (IN CM): N/A

BASE DIAMETER (IN CM) AND SHAPE

OF BASE: 6.0; circular and rounded

ESTIMATED VOLUME (IN LITERS): 0.12

DECORATION (INCLUDING MOTIF AND ELEMENTS WHEN APPARENT): Plain

(Figure 9)

PIGMENT USE AND LOCATION

ON VESSEL: none

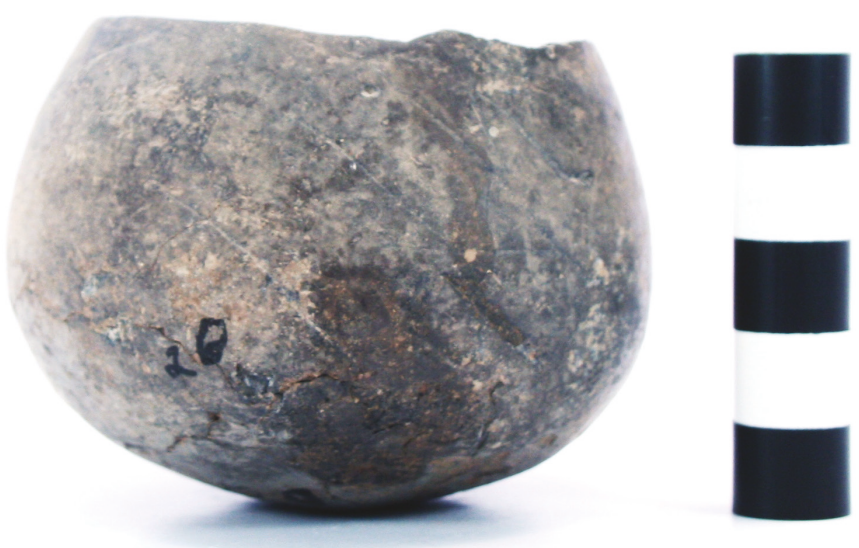

Figure 9. Bois d'Arc Plain bowl from the T. M.

TYPE AND VARIETY

Sanders site (41LR2).

(IF KNOWN): Bois d'Arc Plain 
SITE NAME OR SITE NUMBER: T. M. Sanders

VESSEL NO.: 22

VESSEL FORM: Bottle

NON-PLASTICS AND PASTE: grog and bone

RIM AND LIP FORM: N/A

CORE COLOR: $\mathrm{G}$ (fired in a reducing environment and cooled in the open air)

INTERIOR SURFACE COLOR: dark grayish-brown

EXTERIOR SURFACE COLOR: red

WALL THICKNESS (IN MM): body, $6.0 \mathrm{~mm}$; base, $7.7 \mathrm{~mm}$

INTERIOR SURFACE

TREATMENT: none

EXTERIOR SURFACE

TREATMENT: burnished

HEIGHT (IN CM): 11.5+

ORIFICE DIAMETER (IN CM): N/A

DIAMETER AT BOTTOM OF RIM OR NECK (IN CM): 4.7; maximum body diameter is $12.1 \mathrm{~cm}$

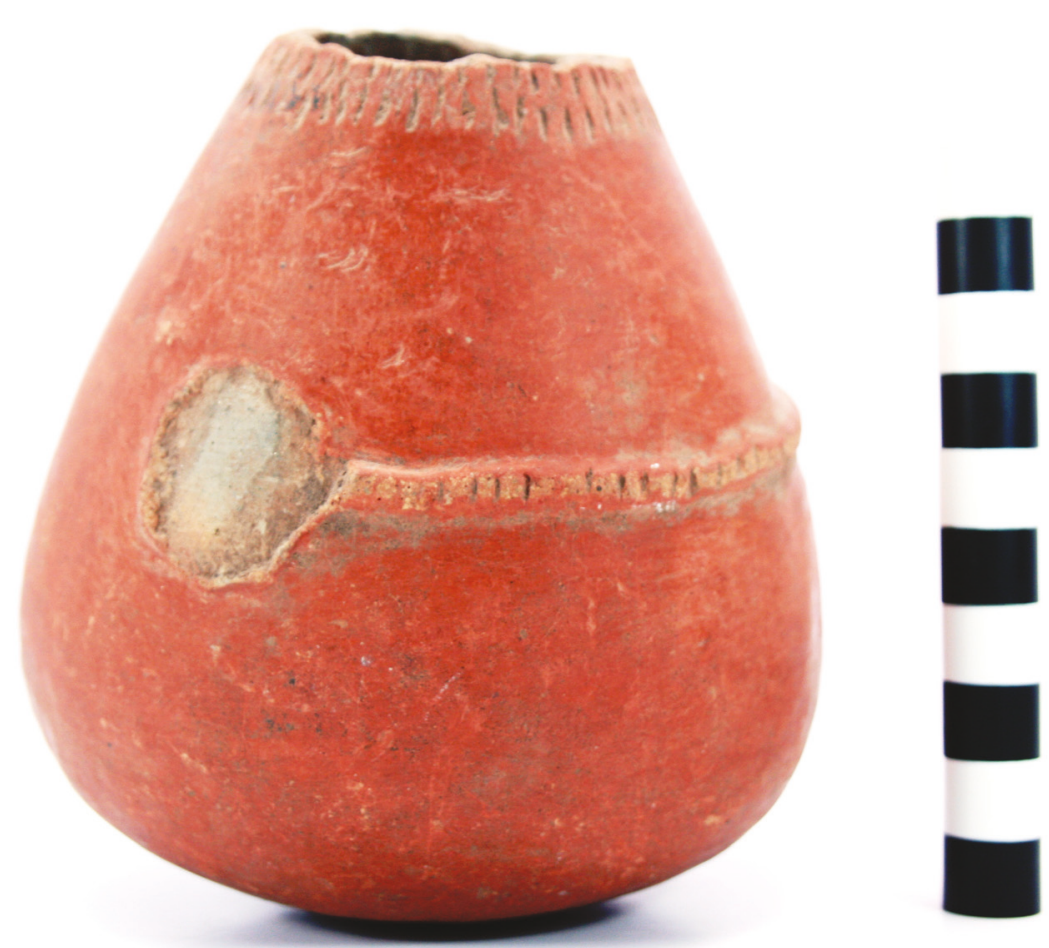

Figure 10. Maxey Noded Redware bottle from the T. M. Sanders site (41LR2).

BASE DIAMETER (IN CM) AND SHAPE OF BASE: 9.8; circular and rounded

ESTIMATED VOLUME (IN LITERS): 0.44+

DECORATION (INCLUDING MOTIF AND ELEMENTS WHEN APPARENT): The vessel has a red slip on its exterior surface. There are also two horizontal rows of fingernail punctations on the upper part of the vessel body, above two large ( $25 \mathrm{~mm}$ diameter) appliqued nodes connected by a horizontal appliqued fillet (Figure 10).

PIGMENT USE AND LOCATION ON VESSEL: none

TYPE AND VARIETY (IF KNOWN): Maxey Noded Redware 
SITE NAME OR SITE NUMBER: T. M. Sanders

VESSEL NO.: 22A

VESSEL FORM: Bottle

NON-PLASTICS AND PASTE: grog

RIM AND LIP FORM: N/A

CORE COLOR: $\mathrm{G}$ (fired in a reducing environment and cooled in the open air)

INTERIOR SURFACE COLOR: very dark grayish-brown

EXTERIOR SURFACE COLOR: red

WALL THICKNESS (IN MM): body, $6.0 \mathrm{~mm}$

INTERIOR SURFACE TREATMENT: none

EXTERIOR SURFACE TREATMENT: smoothed

HEIGHT (IN CM): 15.8+

ORIFICE DIAMETER (IN CM): N/A

DIAMETER AT BOTTOM OF RIM OR NECK (IN CM): 5.5; maximum body diameter is $16.5 \mathrm{~cm}$

BASE DIAMETER (IN CM) AND SHAPE OF BASE: 8.0; circular and rounded

ESTIMATED VOLUME (IN LITERS):

0.5



Figure 11. Maxey Noded Redware bottle from the T. M. Sanders site (41LR2).

DECORATION (INCLUDING MOTIF AND ELEMENTS WHEN APPARENT): The vessel exterior surface has a red slip. There are also three vertical rows of three oval appliqued nodes that extend from the top of the vessel body to the base (Figure 11).

PIGMENT USE AND LOCATION ON VESSEL: none

TYPE AND VARIETY (IF KNOWN): Maxey Noded Redware 
SITE NAME OR SITE NUMBER: T. M. Sanders

VESSEL NO.: 23

VESSEL FORM: Bottle

NON-PLASTICS AND PASTE: bone

RIM AND LIP FORM: Missing

CORE COLOR: $\mathrm{G}$ (fired in a reducing environment and cooled in the open air)

INTERIOR SURFACE COLOR: very dark grayish-brown

EXTERIOR SURFACE COLOR: red; fire clouds on the base

WALL THICKNESS (IN MM): body, $6.8 \mathrm{~mm}$

INTERIOR SURFACE TREATMENT: none

EXTERIOR SURFACE TREATMENT:

burnished

HEIGHT (IN CM): 15.0+

ORIFICE DIAMETER (IN CM): 5.1

DIAMETER AT BOTTOM OF RIM OR

NECK (IN CM): 5.1; maximum body diameter is $12.7 \mathrm{~cm}$

BASE DIAMETER (IN CM) AND SHAPE

OF BASE: 8.3; circular and rounded

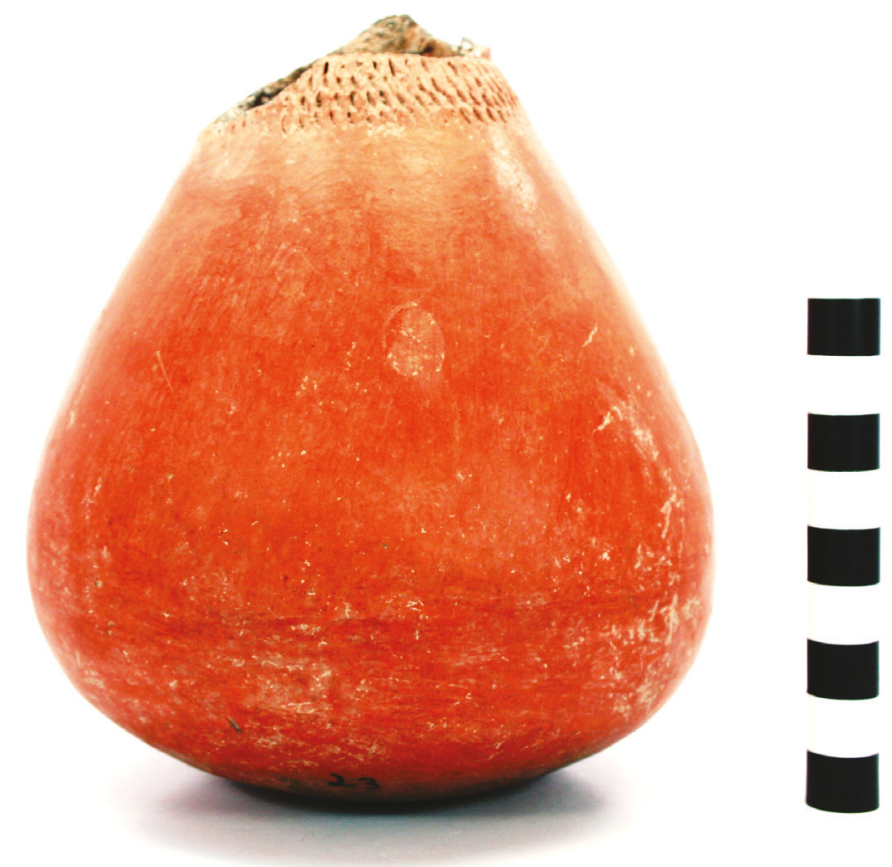

Figure 12. Maxey Noded Redware bottle from the T. M. Sanders site (41LR2).

ESTIMATED VOLUME (IN LITERS): 0.5+

DECORATION (INCLUDING MOTIF AND ELEMENTS WHEN APPARENT): There is a red slip on the exterior surface of the vessel. There are also four closely-spaced rows of tool punctations at the top of the vessel body (Figure 12).

PIGMENT USE AND LOCATION ON VESSEL: none

TYPE AND VARIETY (IF KNOWN): Maxey Noded Redware 
SITE NAME OR SITE NUMBER: T. M. Sanders

VESSEL NO.: 25

VESSEL FORM: Jar

NON-PLASTICS AND PASTE: grog

RIM AND LIP FORM: Direct rim and rounded lip

CORE COLOR: B (fired and cooled in a reducing environment)

INTERIOR SURFACE COLOR: very dark grayish-brown; fire clouds on the rim and body

EXTERIOR SURFACE COLOR: very dark grayish-brown

WALL THICKNESS (IN MM): rim, 7.9 mm

INTERIOR SURFACE TREATMENT:

smoothed

EXTERIOR SURFACE TREATMENT:

burnished

HEIGHT (IN CM): 13.4

ORIFICE DIAMETER (IN CM): 11.8

DIAMETER AT BOTTOM OF RIM OR NECK (IN CM): 12.0

BASE DIAMETER (IN CM) AND SHAPE OF BASE: 7.0; circular and flat

ESTIMATED VOLUME (IN LITERS): 0.95

DECORATION (INCLUDING MOTIF AND ELEMENTS WHEN APPARENT): Plain



Figure 13. Bois d'Arc Plain jar from the T. M. Sanders site (41LR2).

(Figure 13)

PIGMENT USE AND LOCATION ON VESSEL: none

TYPE AND VARIETY (IF KNOWN): Bois d'Arc Plain 
SITE NAME OR SITE NUMBER: T. M. Sanders

VESSEL NO.: 26

VESSEL FORM: Bowl with two opposed lip tabs (10 x $15 \mathrm{~mm}$ in height and width)

NON-PLASTICS AND PASTE: grog

RIM AND LIP FORM: Direct rim and rounded lip

CORE COLOR: F (fired in a reducing environment and cooled in the open air)

INTERIOR SURFACE COLOR: dark yellowish-brown; fire clouds on the rim and body

EXTERIOR SURFACE COLOR: dark yellowish-brown; fire clouds on the body and base

WALL THICKNESS (IN MM): rim, $6.2 \mathrm{~mm}$

INTERIOR SURFACE TREATMENT: smoothed

EXTERIOR SURFACE

TREATMENT: smoothed

HEIGHT (IN CM): 10.8

ORIFICE DIAMETER (IN CM):

11.8

DIAMETER AT BOTTOM OF

RIM OR NECK (IN CM): N/A

BASE DIAMETER (IN CM) AND

SHAPE OF BASE: 7.6; circular and flat

ESTIMATED VOLUME (IN

LITERS): 0.51

DECORATION (INCLUDING

MOTIF AND ELEMENTS WHEN

APPARENT): Plain (Figure 14)

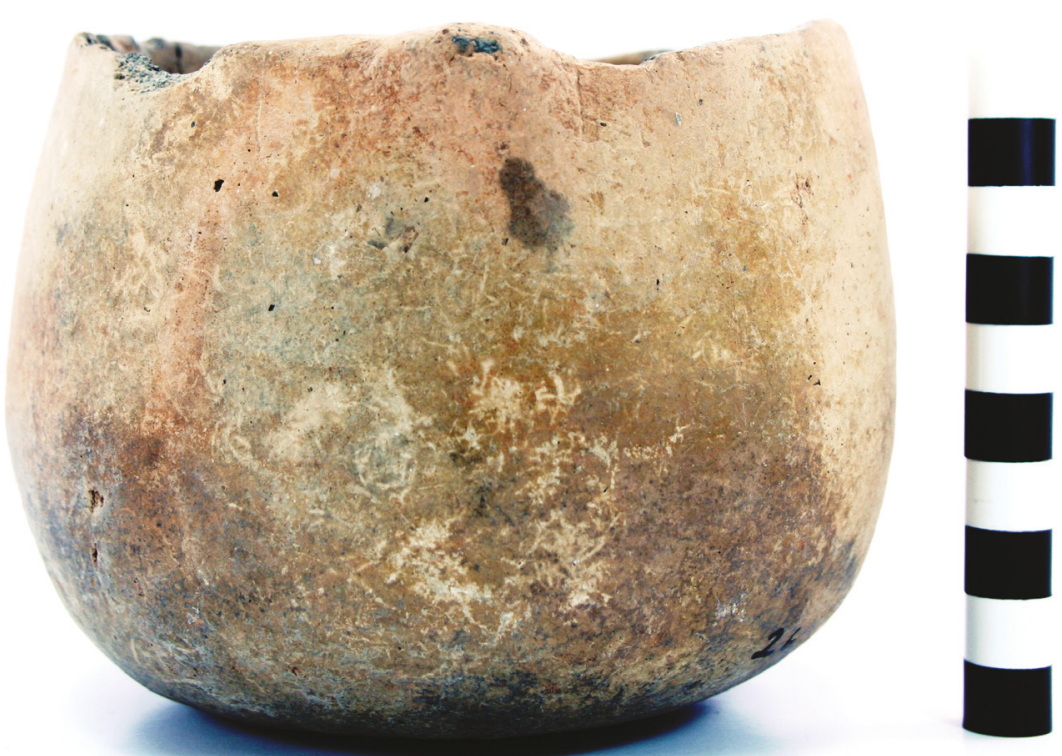

Figure 14. Bois d'Arc Plain bowl from the T. M. Sanders site.

PIGMENT USE AND LOCATION ON VESSEL: none

TYPE AND VARIETY (IF KNOWN): Bois d'Arc Plain 
SITE NAME OR SITE NUMBER: T. M. Sanders

VESSEL NO.: 27

VESSEL FORM: Bowl with opposed lip tabs (5 x $17 \mathrm{~mm}$ in height and width)

NON-PLASTICS AND PASTE: grog

RIM AND LIP FORM: Inverted rim and rounded lip

CORE COLOR: $\mathrm{F}$ (fired in a reducing environment and cooled in the open air)

INTERIOR SURFACE COLOR: yellowish-brown; fire clouds on the body

EXTERIOR SURFACE COLOR: yellowish-brown; fire clouds on the rim and body

WALL THICKNESS (IN MM):

rim, $5.6 \mathrm{~mm}$

INTERIOR SURFACE

TREATMENT: none

EXTERIOR SURFACE

TREATMENT: none

HEIGHT (IN CM): 9.1

ORIFICE DIAMETER

(IN CM): 10.0

DIAMETER AT BOTTOM OF

RIM OR NECK (IN CM): N/A

BASE DIAMETER (IN CM)

AND SHAPE OF BASE: 10.2;

circular and flat

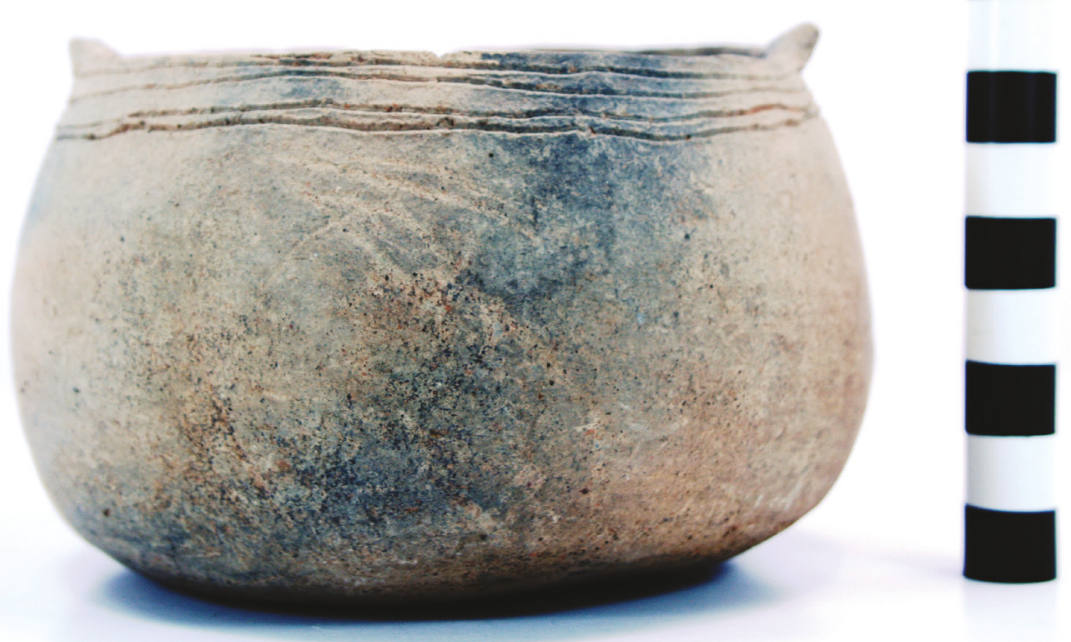

Figure 15. East Incised bowl from the T. M. Sanders site (41LR2).

ESTIMATED VOLUME (IN LITERS): 0.36

DECORATION (INCLUDING MOTIF AND ELEMENTS WHEN APPARENT): There are four closelyspaced horizontal incised lines on the vessel rim (Figure 15).

PIGMENT USE AND LOCATION ON VESSEL: none

TYPE AND VARIETY (IF KNOWN): East Incised (Suhm and Jelks 1962:41). 


\section{Vessels from Excavations in Mound No. 1 (East Mound)}

The 1931 excavations by University of Texas archaeologists in Mound No. 1 at the T. M. Sanders site recovered 59 ceramic vessels associated with numerous burial features. The excavations of these burials, and an inventory of associated funerary offerings, is provided by Jackson (2000:12-33).

SITE NAME OR SITE NUMBER: T. M. Sanders

VESSEL NO.: 254, Burial B-1

VESSEL FORM: Carinated bowl

NON-PLASTICS AND PASTE: grog

RIM AND LIP FORM: Direct rim and rounded lip

CORE COLOR: F (fired in a reducing environment and cooled in the open air)

INTERIOR SURFACE COLOR: dark yellowish-brown

EXTERIOR SURFACE COLOR: yellowish-brown; fire clouds on the body and base

WALL THICKNESS (IN MM): rim, $7.0 \mathrm{~mm}$

INTERIOR SURFACE TREATMENT: smoothed

EXTERIOR SURFACE TREATMENT: burnished

HEIGHT (IN CM): 11.5

ORIFICE DIAMETER (IN CM):

27.0

DIAMETER AT BOTTOM OF

RIM OR NECK (IN CM): 27.0

BASE DIAMETER (IN CM)

AND SHAPE OF BASE: 10.2;

circular and flat

ESTIMATED VOLUME

(IN LITERS): 1.9



Figure 16. Sanders Engraved carinated bowl in Burial B-1 at the T. M. Sanders site (41LR2).

DECORATION (INCLUDING MOTIF AND ELEMENTS WHEN APPARENT): The rim panel has 12 upper and 12 lower large engraved triangle elements filled with cross-hatched lines. The engraved triangle elements reach from the vessel lip to the vessel carination (Figure 16).

PIGMENT USE AND LOCATION ON VESSEL: red pigment in the engraved lines

TYPE AND VARIETY (IF KNOWN): Sanders Engraved 
SITE NAME OR SITE NUMBER: T. M. Sanders

VESSEL NO.: 255, Burial B-1

VESSEL FORM: Bottle with a carinated body

NON-PLASTICS AND PASTE: grog and bone

RIM AND LIP FORM: Direct rim and rounded lip

CORE COLOR: $\mathrm{F}$ (fired in a reducing

environment and cooled in the open air)

INTERIOR SURFACE COLOR: reddish-brown

EXTERIOR SURFACE COLOR: red

WALL THICKNESS (IN MM): rim, 5.9 mm

INTERIOR SURFACE TREATMENT: none

EXTERIOR SURFACE TREATMENT: burnished

HEIGHT (IN CM): 25.7

ORIFICE DIAMETER (IN CM): 4.4

DIAMETER AT BOTTOM OF RIM

OR NECK (IN CM): 5.1; maximum body diameter is $15.9 \mathrm{~cm}$

BASE DIAMETER (IN CM) AND SHAPE OF BASE: 11.5; circular and flat

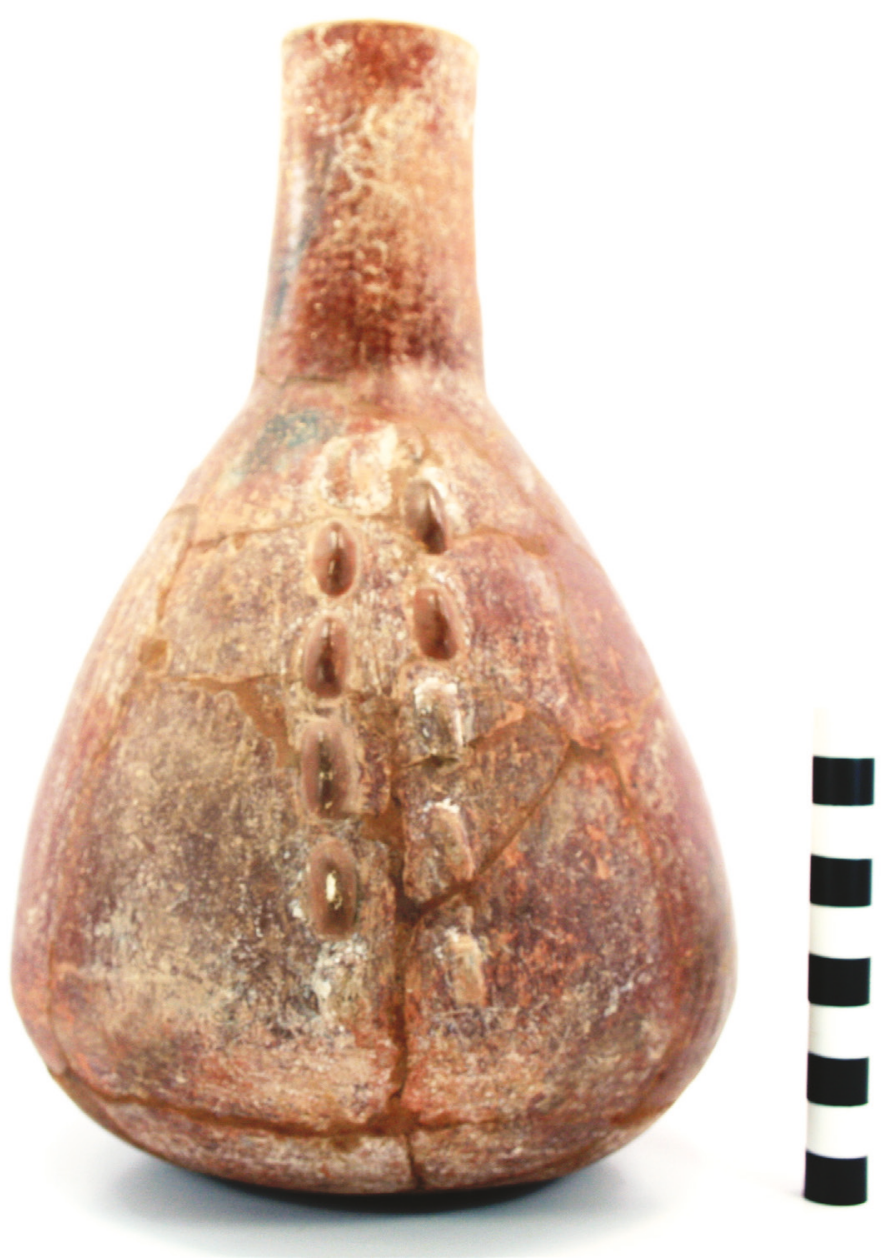

Figure 17. Maxey Noded Redware bottle in Burial B-1 at the T. M. Sanders site (41LR2).

ESTIMATED VOLUME (IN LITERS): 1.2

DECORATION (INCLUDING MOTIF AND ELEMENTS WHEN APPARENT): The vessel exterior has a red slip. There are also three separate vertical columns with two rows of appliqued nodes (14-15 mm in length) on the vessel body (Figure 17).

PIGMENT USE AND LOCATION ON VESSEL: none

TYPE AND VARIETY (IF KNOWN): Maxey Noded Redware 
SITE NAME OR SITE NUMBER: T. M. Sanders

VESSEL NO.: 267, Burial B-2

VESSEL FORM: Bottle

NON-PLASTICS AND PASTE: grog

RIM AND LIP FORM: Direct rim and rounded lip

CORE COLOR: $F$ (fired in a reducing environment and cooled in the open air)

INTERIOR SURFACE COLOR: red on the interior neck

EXTERIOR SURFACE COLOR: red

WALL THICKNESS (IN MM): rim, $5.2 \mathrm{~mm}$

INTERIOR SURFACE TREATMENT: none

EXTERIOR SURFACE TREATMENT: smoothed

HEIGHT (IN CM): 24.8

ORIFICE DIAMETER (IN CM): 4.0

DIAMETER AT BOTTOM OF RIM OR NECK (IN

$\mathrm{CM}$ ): 5.9 ; maximum body diameter of $17.8 \mathrm{~cm}$

BASE DIAMETER (IN CM) AND SHAPE OF

BASE: 10.0 ; circular and flat

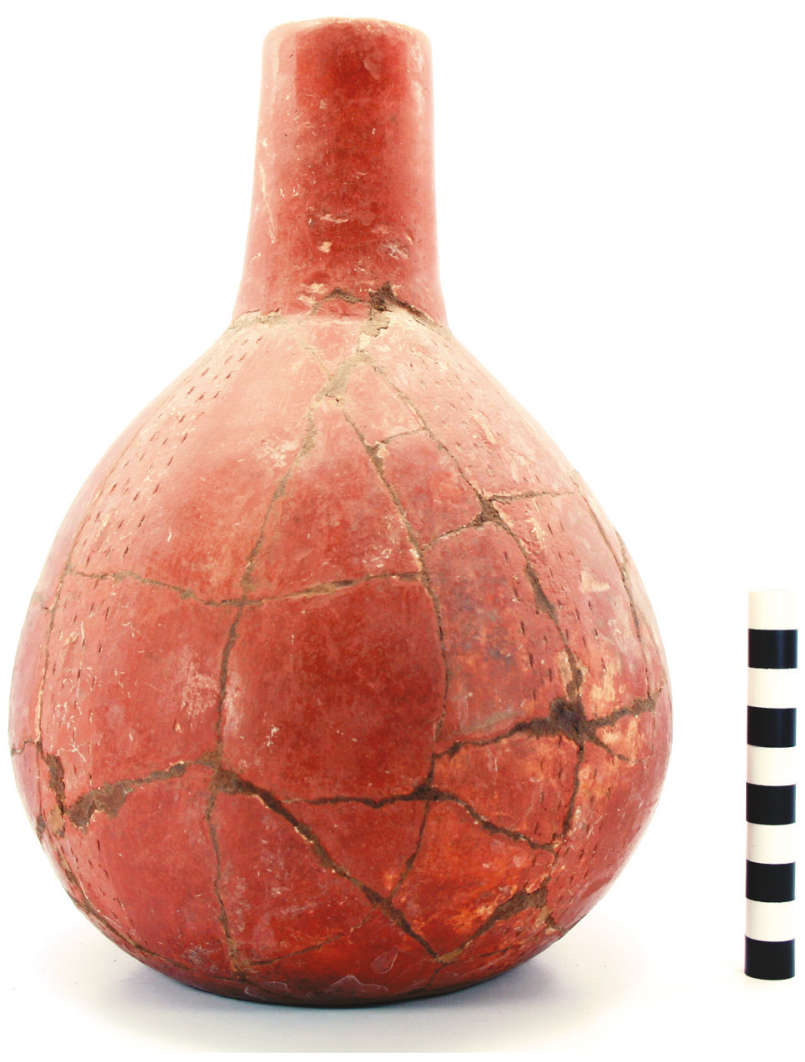

Figure 18. Maxey Noded Redware bottle in

Burial B-2 at the T. M. Sanders site (41LR2).

ESTIMATED VOLUME (IN LITERS): 1.0

DECORATION (INCLUDING MOTIF AND ELEMENTS WHEN APPARENT): The vessel exterior and interior neck have a red slip. The exterior body also has four columns of low oval appliqued nodes that are surrounded by nine vertical rows of five tool punctations (Figure 18).

PIGMENT USE AND LOCATION ON VESSEL: none

TYPE AND VARIETY (IF KNOWN): Maxey Noded Redware 
SITE NAME OR SITE NUMBER: T. M. Sanders

VESSEL NO.: 276, Burial B-3

VESSEL FORM: Bowl

NON-PLASTICS AND PASTE: grog

RIM AND LIP FORM: Direct rim and rounded lip

CORE COLOR: B (fired and cooled in a reducing environment)

INTERIOR SURFACE COLOR: grayish-brown; fire clouds on the body and base

EXTERIOR SURFACE COLOR: grayish-brown; fire clouds on the body and base

WALL THICKNESS (IN MM):

rim, $7.8 \mathrm{~mm}$; body, $9.0 \mathrm{~mm}$; base, $9.5 \mathrm{~mm}$

INTERIOR SURFACE

TREATMENT: smoothed

EXTERIOR SURFACE

TREATMENT: smoothed

HEIGHT (IN CM): 11.5

ORIFICE DIAMETER (IN CM):

18.0

DIAMETER AT BOTTOM OF

RIM OR NECK (IN CM): N/A

BASE DIAMETER (IN CM)

AND SHAPE OF BASE: 6.0;

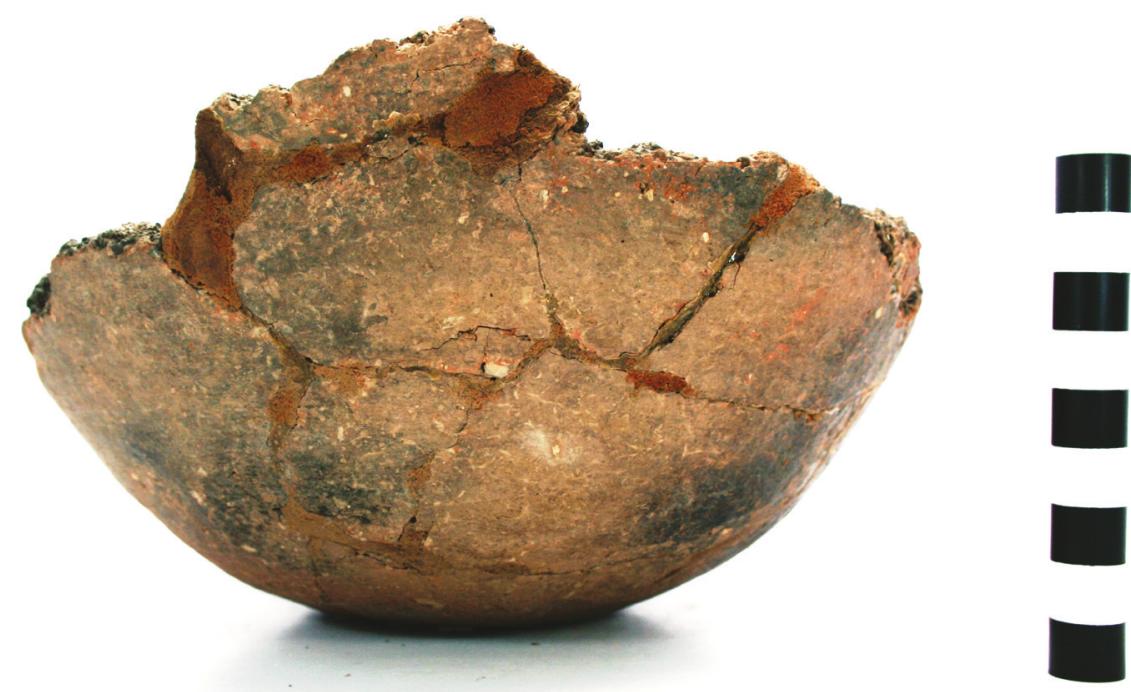

Figure 19. Bois d'Arc Plain bowl in Burial B-3 at the T. M. Sanders site (41LR2).

circular and rounded

ESTIMATED VOLUME (IN LITERS): 0.87

DECORATION (INCLUDING MOTIF AND ELEMENTS WHEN APPARENT): Plain (Figure 19)

PIGMENT USE AND LOCATION ON VESSEL: none

TYPE AND VARIETY (IF KNOWN): Bois d'Arc Plain 
SITE NAME OR SITE NUMBER: T. M. Sanders

VESSEL NO.: 277, Burial B-4

VESSEL FORM: Carinated bowl

NON-PLASTICS AND PASTE: grog

RIM AND LIP FORM: Direct rim and rounded lip

CORE COLOR: F (fired in a reducing environment and cooled in the open air)

INTERIOR SURFACE COLOR: red

EXTERIOR SURFACE COLOR: red

WALL THICKNESS (IN MM): rim, $8.0 \mathrm{~mm}$

INTERIOR SURFACE

TREATMENT: burnished

EXTERIOR SURFACE

TREATMENT: burnished

HEIGHT (IN CM): 15.0

ORIFICE DIAMETER (IN

$\mathrm{CM}): 35.0$

DIAMETER AT BOTTOM OF

RIM OR NECK (IN CM): 35.0

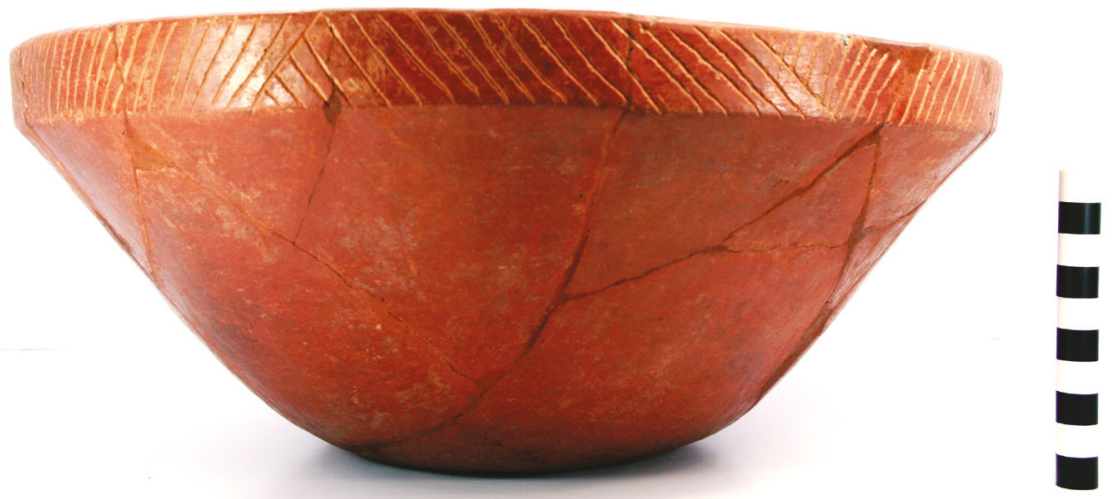

Figure 20. Sanders Engraved carinated bowl in Burial

BASE DIAMETER (IN CM)

B-4 at the T. M. Sanders site (41LR2).

AND SHAPE OF BASE: 11.3;

circular and flat

ESTIMATED VOLUME (IN LITERS): 4.7

DECORATION (INCLUDING MOTIF AND ELEMENTS WHEN APPARENT): The vessel has a red slip on both interior and exterior surfaces. It also has 10 sets of diagonal opposed engraved lines on the rim panel (Figure 20).

PIGMENT USE AND LOCATION ON VESSEL: white pigment in engraved lines

TYPE AND VARIETY (IF KNOWN): Sanders Engraved 
SITE NAME OR SITE NUMBER: T. M. Sanders

VESSEL NO.: 280, Burial B-4

VESSEL FORM: Bottle

NON-PLASTICS AND PASTE: grog

RIM AND LIP FORM: Direct rim and rounded lip

CORE COLOR: G (fired in a reducing environment and cooled in the open air)

INTERIOR SURFACE COLOR: very dark grayish-brown

EXTERIOR SURFACE COLOR: dark reddish-brown

WALL THICKNESS (IN MM): rim, 5.4 mm

INTERIOR SURFACE TREATMENT: none

EXTERIOR SURFACE TREATMENT:

smoothed

HEIGHT (IN CM): 17.4

ORIFICE DIAMETER (IN CM): 3.1

DIAMETER AT BOTTOM OF RIM OR NECK (IN CM): 4.7; maximum body diameter is $12.0 \mathrm{~cm}$

BASE DIAMETER (IN CM) AND SHAPE OF BASE: 8.3; circular and flat

ESTIMATED VOLUME (IN LITERS): 0.58

DECORATION (INCLUDING MOTIF AND ELEMENTS WHEN APPARENT): Plain

(Figure 21)

PIGMENT USE AND LOCATION

ON VESSEL: none

TYPE AND VARIETY (IF KNOWN):

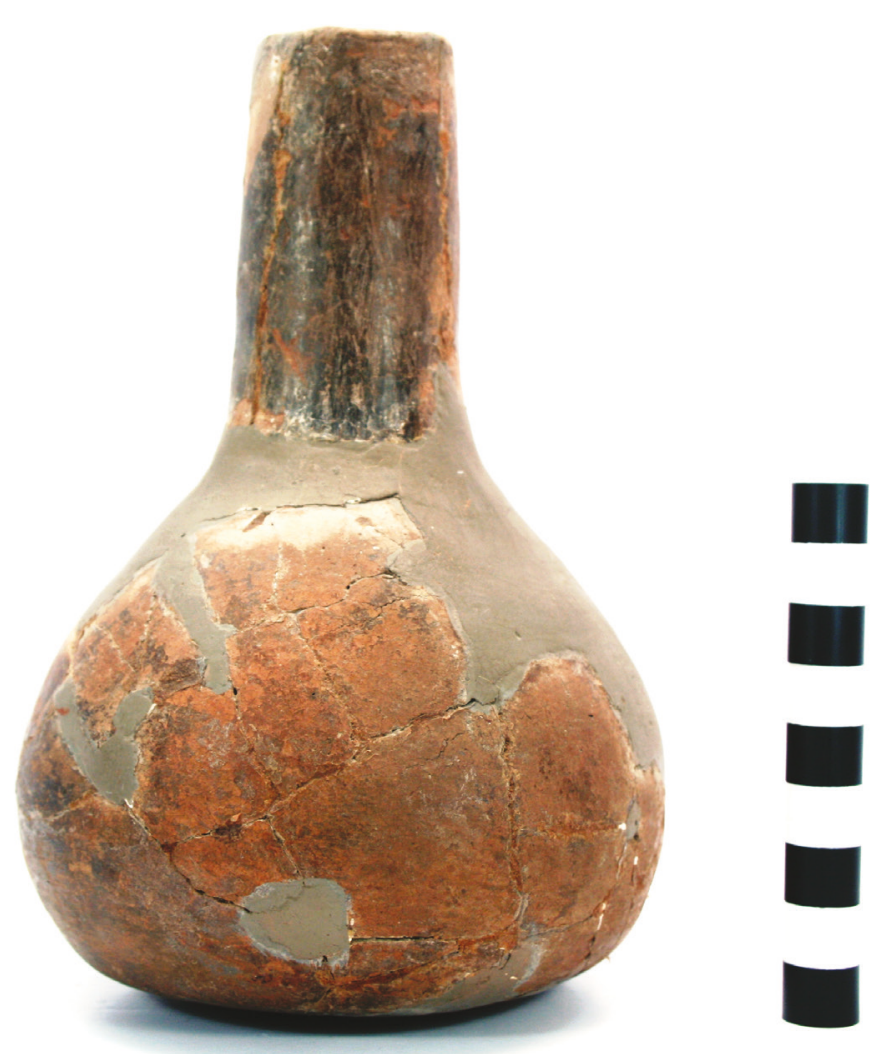

Figure 21. Bois d'Arc Plain bottle in Burial B-4 at the T. M. Sanders site (41LR2).

Bois d'Arc Plain 
SITE NAME OR SITE NUMBER: T. M. Sanders

VESSEL NO.: 297, Burial B-5

VESSEL FORM: Bottle with a wide neck

NON-PLASTICS AND PASTE: grog

RIM AND LIP FORM: Direct rim and rounded lip

CORE COLOR: $\mathrm{G}$ (fired in a reducing environment and cooled in the open air)

INTERIOR SURFACE COLOR: grayish-brown

EXTERIOR SURFACE COLOR: reddish-brown; fire clouds on the body

WALL THICKNESS (IN MM): rim, $4.8 \mathrm{~mm}$

INTERIOR SURFACE TREATMENT: none

EXTERIOR SURFACE TREATMENT: smoothed

HEIGHT (IN CM): 12.5

ORIFICE DIAMETER (IN CM): 6.5

DIAMETER AT BOTTOM OF RIM OR NECK (IN $\mathrm{CM}$ ): 7.4; maximum body diameter is $9.7 \mathrm{~cm}$

BASE DIAMETER (IN CM) AND SHAPE OF BASE: 5.5; circular and flat

ESTIMATED VOLUME (IN LITERS): 0.28

DECORATION (INCLUDING MOTIF AND ELEMENTS WHEN APPARENT): Plain (Figure 22)

PIGMENT USE AND LOCATION ON VESSEL: none

TYPE AND VARIETY (IF KNOWN): Bois d'Arc Plain

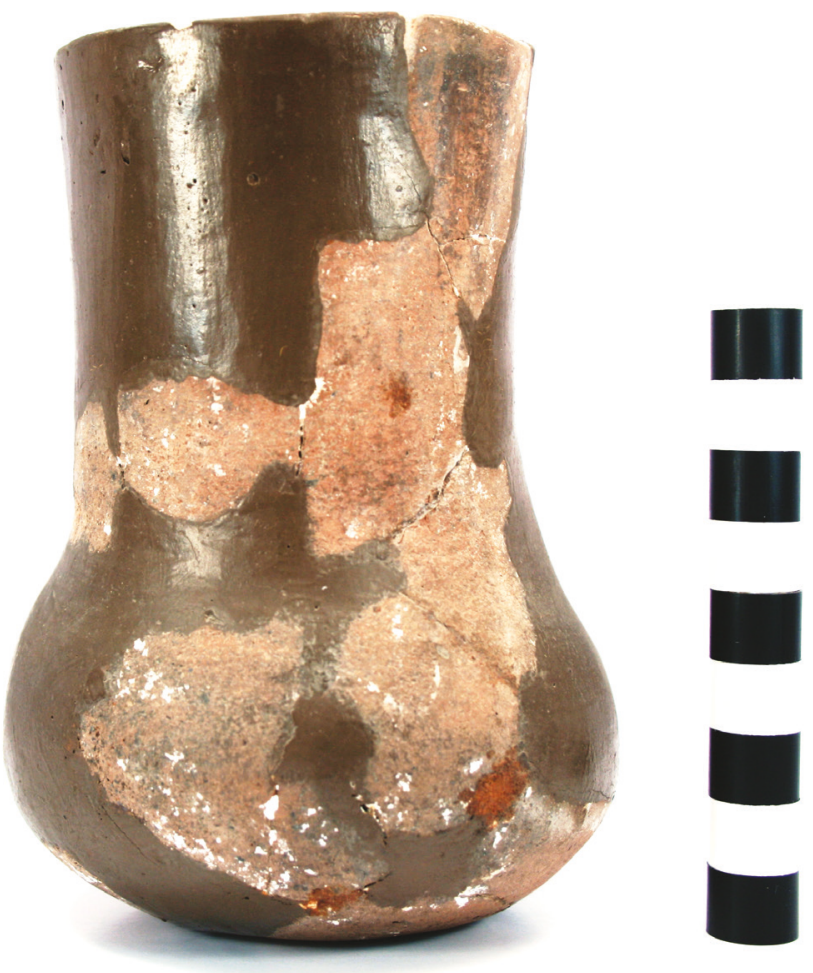

Figure 22. Bois d'Arc Plain bottle in Burial B-5 at the T. M. Sanders site (41LR2). 
SITE NAME OR SITE NUMBER: T. M. Sanders

VESSEL NO.: 298, Burial B-5

VESSEL FORM: Jar with two strap handles $(32 \times 11 \mathrm{~mm}$ in height and width)

NON-PLASTICS AND PASTE: grog

RIM AND LIP FORM: Everted rim and rounded lip

CORE COLOR: $\mathrm{G}$ (fired in a reducing environment and cooled in the open air)

INTERIOR SURFACE COLOR: dark grayish-brown

EXTERIOR SURFACE COLOR: dark yellowish-brown; fire clouds on the rim and body

WALL THICKNESS (IN MM): rim, $4.5 \mathrm{~mm}$

INTERIOR SURFACE

TREATMENT: none

EXTERIOR SURFACE

TREATMENT: none

HEIGHT (IN CM): 12.4

ORIFICE DIAMETER (IN CM):

12.3

DIAMETER AT BOTTOM OF RIM

OR NECK (IN CM): 11.9

BASE DIAMETER (IN CM) AND SHAPE OF BASE: 3.7 ; circular and rounded

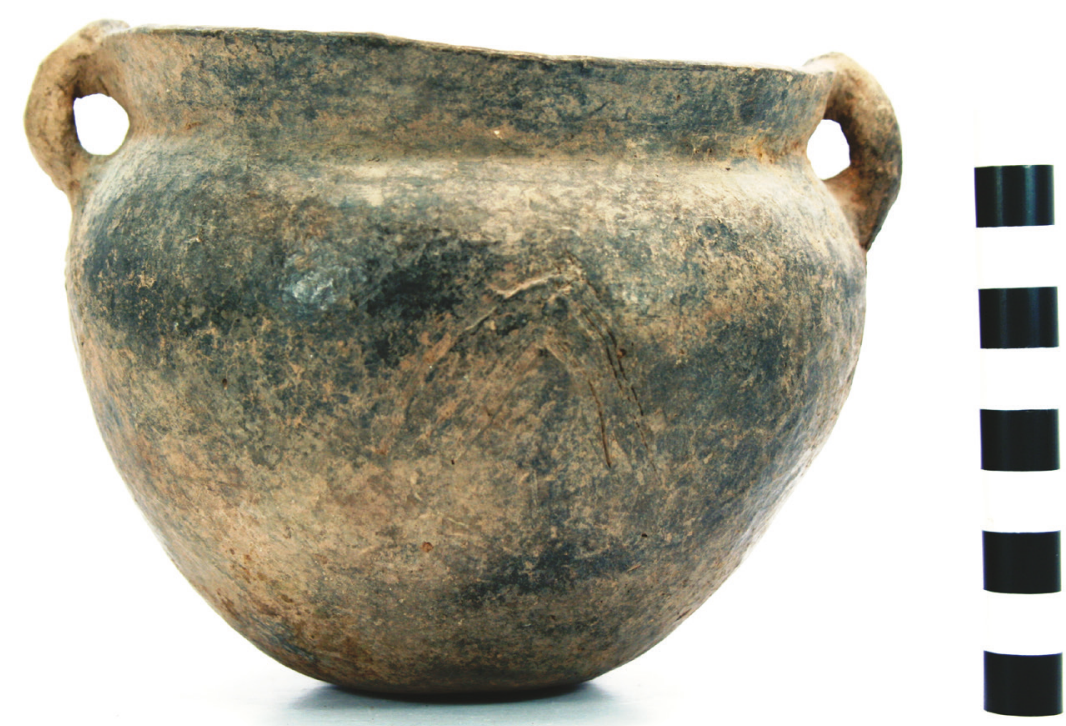

Figure 23. Incised jar in Burial B-5 at the T. M. Sanders site (41LR2).

ESTIMATED VOLUME (IN LITERS): 0.9

DECORATION (INCLUDING MOTIF AND ELEMENTS WHEN APPARENT): The vessel body has a series of four incised triangles, with a smaller incised triangle within the larger element. Two of the incised triangles are directly under the strap handles, and the other two are equally-spaced around the vessel (Figure 23).

PIGMENT USE AND LOCATION ON VESSEL: none

TYPE AND VARIETY (IF KNOWN): Unidentified utility ware 
SITE NAME OR SITE NUMBER: T. M. Sanders

VESSEL NO.: 299, Burial B-5

VESSEL FORM: Bottle

NON-PLASTICS AND PASTE: grog

RIM AND LIP FORM: Direct rim and rounded lip

CORE COLOR: $\mathrm{G}$ (fired in a reducing environment and cooled in the open air)

INTERIOR SURFACE COLOR: dark grayish-brown

EXTERIOR SURFACE COLOR: yellowish-brown; fire clouds on the body

WALL THICKNESS (IN MM): rim, 6.4 mm

INTERIOR SURFACE TREATMENT: none

EXTERIOR SURFACE TREATMENT: smoothed

HEIGHT (IN CM): 17.8

ORIFICE DIAMETER (IN CM): 2.6

DIAMETER AT BOTTOM OF RIM OR

NECK (IN CM): 4.9; maximum body diameter is $12.7 \mathrm{~cm}$

BASE DIAMETER (IN CM) AND SHAPE

OF BASE: 8.3; circular and flat

ESTIMATED VOLUME (IN LITERS):

0.59

DECORATION (INCLUDING MOTIF AND ELEMENTS WHEN APPARENT):

Plain (Figure 24)

PIGMENT USE AND LOCATION ON

VESSEL: none

TYPE AND VARIETY (IF KNOWN):

Bois d'Arc Plain

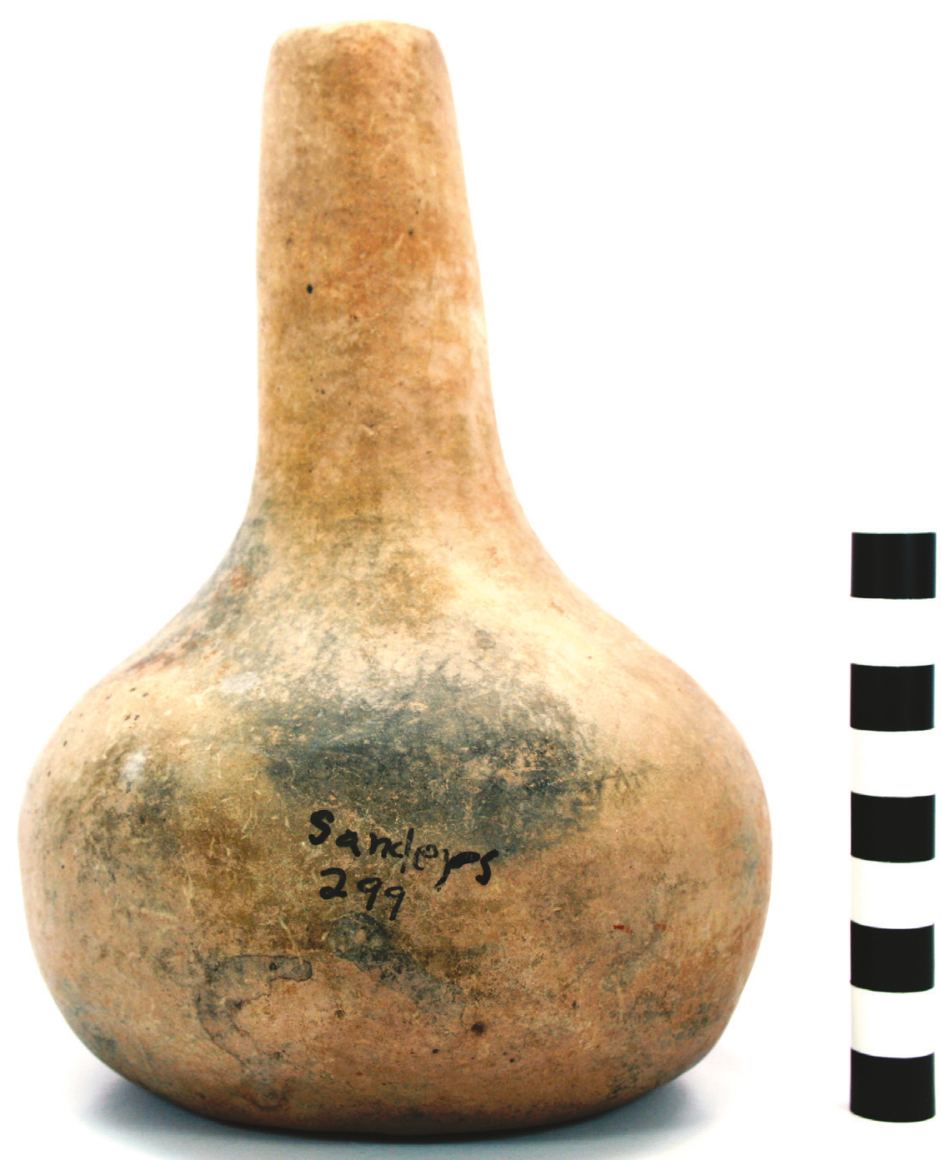

Figure 24. Bois d'Arc Plain bottle in Burial B-5 at the T. M. Sanders site (41LR2). 
SITE NAME OR SITE NUMBER: T. M. Sanders

VESSEL NO.: 302, Burial B-5

VESSEL FORM: Bowl with opposed lip tabs (16 x $26 \mathrm{~mm}$ in height and length)

NON-PLASTICS AND PASTE: grog

RIM AND LIP FORM: Direct rim and rounded lip

CORE COLOR: $\mathrm{G}$ (fired in a reducing environment and cooled in the open air)

INTERIOR SURFACE COLOR: dark grayish-brown

EXTERIOR SURFACE COLOR: dark yellowish-brown; fire clouds on the rim and body

WALL THICKNESS (IN MM): rim, $5.0 \mathrm{~mm}$

INTERIOR SURFACE TREATMENT:

none

EXTERIOR SURFACE TREATMENT:

smoothed

HEIGHT (IN CM): 12.0

ORIFICE DIAMETER (IN CM): 13.4

DIAMETER AT BOTTOM OF RIM OR

NECK (IN CM): N/A

BASE DIAMETER (IN CM) AND

SHAPE OF BASE: 10.2; circular and rounded

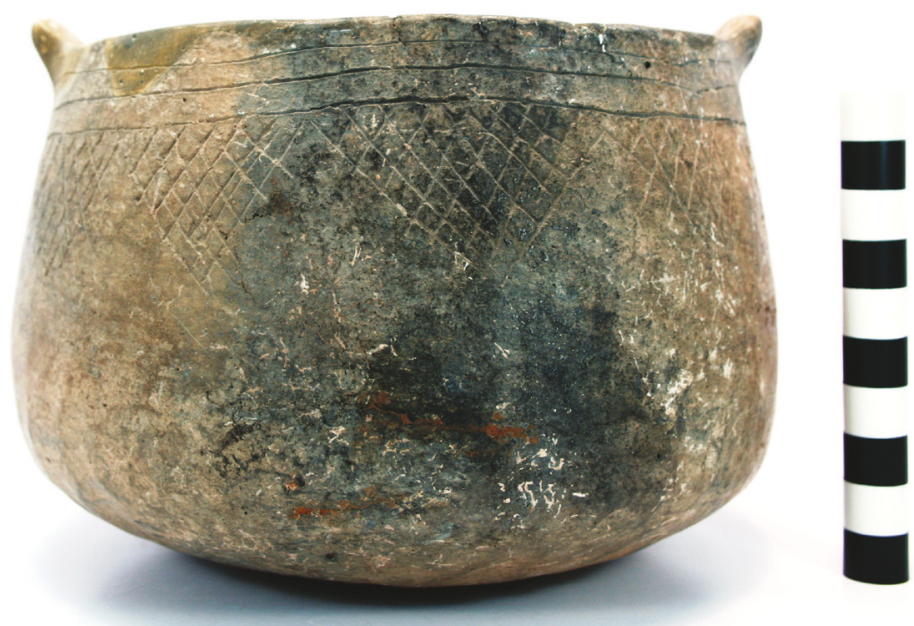

Figure 25. cf. Sanders Engraved bowl in Burial B-5 at the T. M. Sanders site (41LR2).

ESTIMATED VOLUME (IN LITERS): 0.65

DECORATION (INCLUDING MOTIF AND ELEMENTS WHEN APPARENT): The rim of the vessel has three equally-spaced horizontal incised lines, below which are 11 large engraved pendant triangles filled with cross-hatched engraved lines (Figure 25).

PIGMENT USE AND LOCATION ON VESSEL: none

TYPE AND VARIETY (IF KNOWN): cf. Sanders Engraved 
SITE NAME OR SITE NUMBER: T. M. Sanders

VESSEL NO.: 303, Burial B-5

VESSEL FORM: Bottle

NON-PLASTICS AND PASTE: grog and bone

RIM AND LIP FORM: Direct rim and rounded lip

CORE COLOR: F (fired in a reducing environment and cooled in the open air)

INTERIOR SURFACE COLOR: red at the neck

EXTERIOR SURFACE COLOR: red

WALL THICKNESS (IN MM): rim, $4.3 \mathrm{~mm}$

INTERIOR SURFACE TREATMENT: none

EXTERIOR SURFACE TREATMENT: burnished

HEIGHT (IN CM): 15.9

ORIFICE DIAMETER (IN CM): 3.1

DIAMETER AT BOTTOM OF RIM OR NECK

(IN CM): 4.2 ; maximum body diameter is 10.2 $\mathrm{cm}$

BASE DIAMETER (IN CM) AND SHAPE OF BASE: 3.7; circular and rounded

ESTIMATED VOLUME (IN LITERS): 0.24

DECORATION (INCLUDING MOTIF AND ELEMENTS WHEN APPARENT): The vessel has a red slip on both surfaces, although only on the interior surface's neck. There are also four columns of three appliqued nodes and interspersed tool punctations at the top of the vessel body. Between the appliqued-punctated columns are three horizontal rows of tool punctations (Figure 26).

PIGMENT USE AND LOCATION ON VESSEL: none

TYPE AND VARIETY (IF KNOWN): Maxey Noded Redware

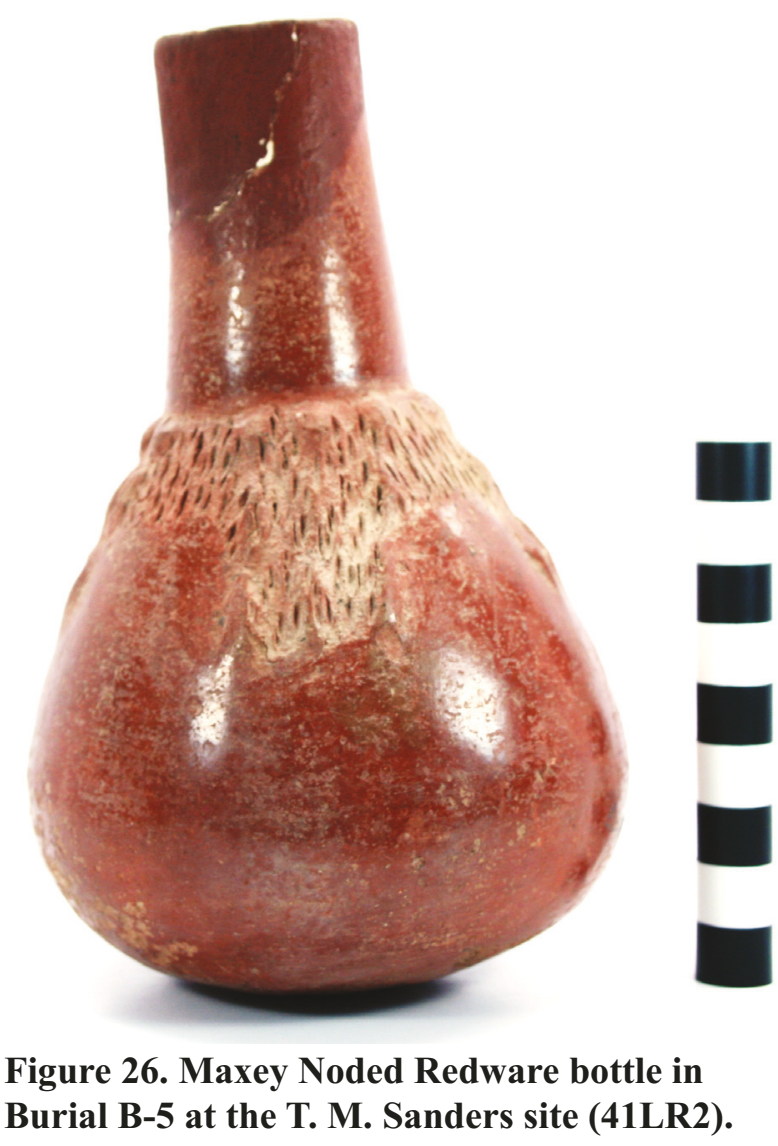


SITE NAME OR SITE NUMBER: T. M. Nelson

VESSEL NO.: 305, Burial B-5

VESSEL FORM: Jar with two strap handles (22 x $11 \mathrm{~mm}$ in height and width)

NON-PLASTICS AND PASTE: grog

RIM AND LIP FORM: Everted rim and rounded lip

CORE COLOR: F (fired in a reducing environment and cooled in the open air)

INTERIOR SURFACE COLOR: reddish-brown; fire clouds on the rim, body, and base

EXTERIOR SURFACE COLOR: reddish-brown; fire clouds on the rim, body, and base

WALL THICKNESS (IN MM): rim, $5.1 \mathrm{~mm}$

INTERIOR SURFACE TREATMENT: none

EXTERIOR SURFACE TREATMENT: none

HEIGHT (IN CM): 6.0

ORIFICE DIAMETER (IN CM): 7.1

DIAMETER AT BOTTOM OF RIM OR NECK (IN CM): 6.9

BASE DIAMETER (IN CM) AND SHAPE OF

BASE: 3.1 ; circular and flat

ESTIMATED VOLUME (IN LITERS): 0.26

DECORATION (INCLUDING MOTIF AND ELEMENTS WHEN APPARENT): There are four appliqued ridge triangle elements on the vessel body. Two of these elements are under the strap handles and the other two are equallyspaced between them (Figure 27).

PIGMENT USE AND LOCATION ON VESSEL: none

TYPE AND VARIETY (IF KNOWN):

Unidentified utility ware

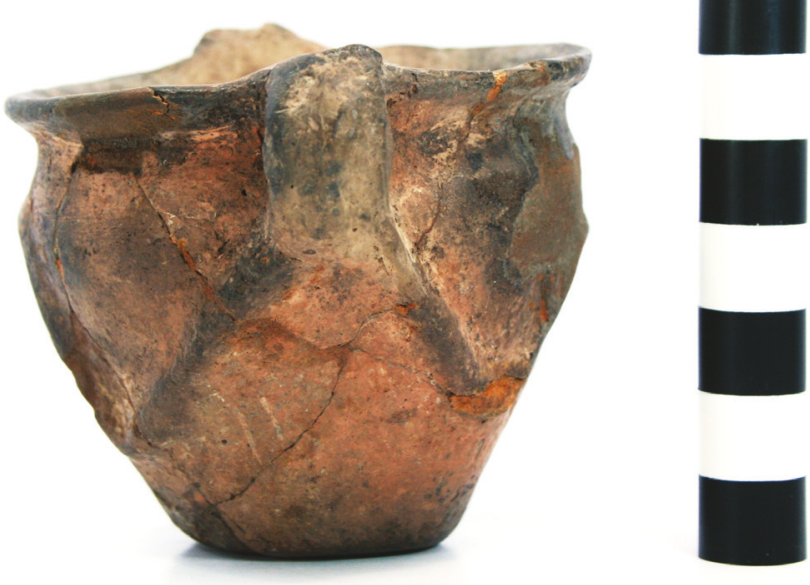

Figure 27. Appliqued jar in Burial B-5 at the T. M. Sanders site (41LR2). 
SITE NAME OR SITE NUMBER: T. M. Sanders

VESSEL NO.: 307, Burial B-6

VESSEL FORM: Carinated bowl

NON-PLASTICS AND PASTE: grog and bone

RIM AND LIP FORM: Everted rim and rounded, scalloped lip

CORE COLOR: F (fired in a reducing environment and cooled in the open air)

INTERIOR SURFACE COLOR: dark yellowish-brown; fire clouds on the rim, body, and base

EXTERIOR SURFACE COLOR: dark yellowish-brown; fire clouds on the body and base

WALL THICKNESS (IN MM): rim, $6.7 \mathrm{~mm}$; body, $7.6 \mathrm{~mm}$

INTERIOR SURFACE TREATMENT: smoothed

EXTERIOR SURFACE TREATMENT: burnished

HEIGHT (IN CM): 12.7

ORIFICE DIAMETER (IN CM): 31.0

DIAMETER AT BOTTOM OF

RIM OR NECK (IN CM): 30.6

BASE DIAMETER (IN CM) AND SHAPE OF BASE: 10.2;

circular and flat

ESTIMATED VOLUME (IN

LITERS): 2.4

DECORATION (INCLUDING

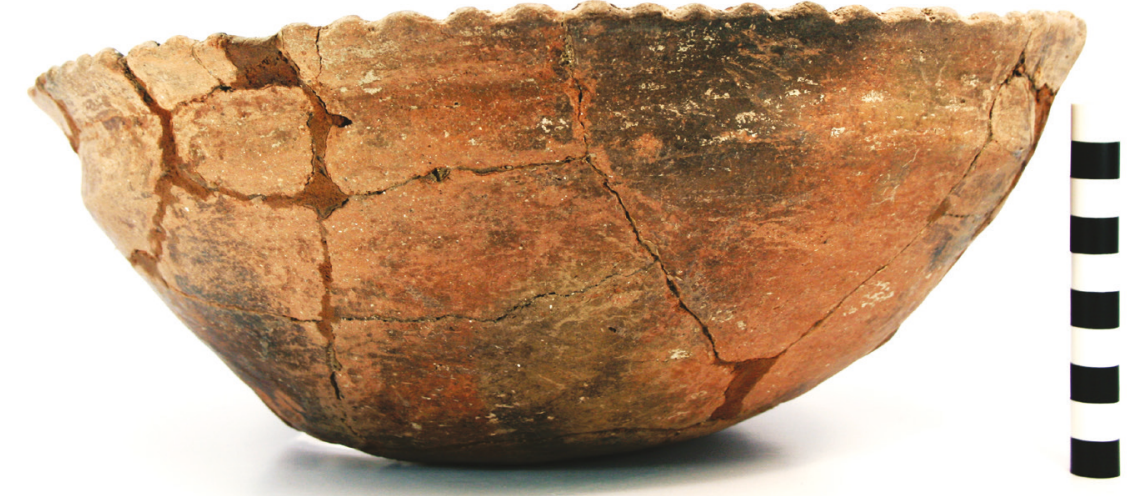

Figure 28. Bois d'Arc Plain, var. Crawford carinated bowl in Burial B-6 at the T. M. Sanders site (41LR2). MOTIF AND ELEMENTS WHEN

APPARENT): Plain (Figure 28)

PIGMENT USE AND LOCATION ON VESSEL: none

TYPE AND VARIETY (IF KNOWN): Bois d'Arc Plain, var. Crawford 
SITE NAME OR SITE NUMBER: T. M. Sanders

VESSEL NO.: 309, Burial B-6

VESSEL FORM: Carinated bowl

NON-PLASTICS AND PASTE: grog and bone

RIM AND LIP FORM: Direct rim and rounded lip

CORE COLOR: $\mathrm{G}$ (fired in a reducing environment and cooled in the open air)

INTERIOR SURFACE COLOR: dark grayish-brown; fire clouds on the body

EXTERIOR SURFACE COLOR: yellowish-brown; fire clouds on the rim, body, and base

WALL THICKNESS (IN MM): rim, $8.1 \mathrm{~mm}$

INTERIOR SURFACE

TREATMENT: smoothed

EXTERIOR SURFACE

TREATMENT: smoothed

HEIGHT (IN CM): 14.2

ORIFICE DIAMETER (IN CM):

31.5

DIAMETER AT BOTTOM OF RIM

OR NECK (IN CM): 31.0

BASE DIAMETER (IN CM) AND SHAPE OF BASE: 10.0; circular

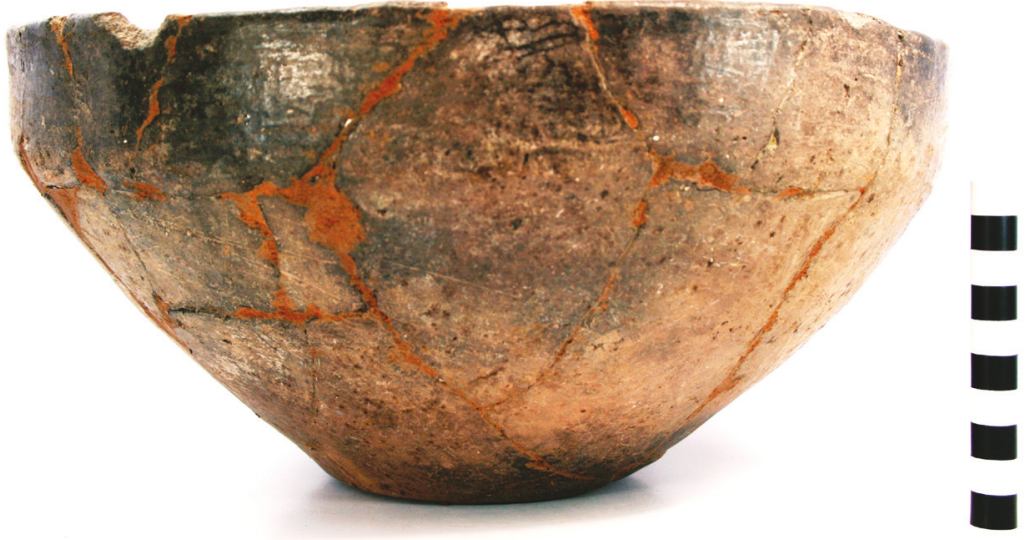

Figure 29. Engraved carinated bowl in Burial B-6 at the T. M. Sanders site (41LR2).

and flat

ESTIMATED VOLUME (IN LITERS): 4.0

DECORATION (INCLUDING MOTIF AND ELEMENTS WHEN APPARENT): The rim panel is decorated with three closely-spaced vertical engraved lines, while the upper 25 percent of the vessel body has erratically executed diagonal and cross-hatched engraved lines (Figure 29).

PIGMENT USE AND LOCATION ON VESSEL: none

TYPE AND VARIETY (IF KNOWN): Unidentified fine ware 
SITE NAME OR SITE NUMBER: T. M. Sanders

VESSEL NO.: 309A, Burial B-6

VESSEL FORM: Bowl with opposed lip tabs (24 x $13 \mathrm{~mm}$ in height and width) (Figure 30)

NON-PLASTICS AND PASTE: grog

RIM AND LIP FORM: Direct rim and a flat lip

CORE COLOR: B (fired and cooled in a reducing environment)

INTERIOR SURFACE COLOR: very dark grayish-brown

EXTERIOR SURFACE COLOR: grayish-brown

WALL THICKNESS (IN

$\mathrm{MM})$ : rim, $5.7 \mathrm{~mm}$

INTERIOR SURFACE

TREATMENT: none

EXTERIOR SURFACE

TREATMENT: smoothed

HEIGHT (IN CM): 10.2

ORIFICE DIAMETER (IN

$\mathrm{CM}): 13.4$

DIAMETER AT BOTTOM

OF RIM OR NECK (IN

$\mathrm{CM}): \mathrm{N} / \mathrm{A}$

BASE DIAMETER (IN CM) AND SHAPE OF BASE: 8.3;

circular and flat

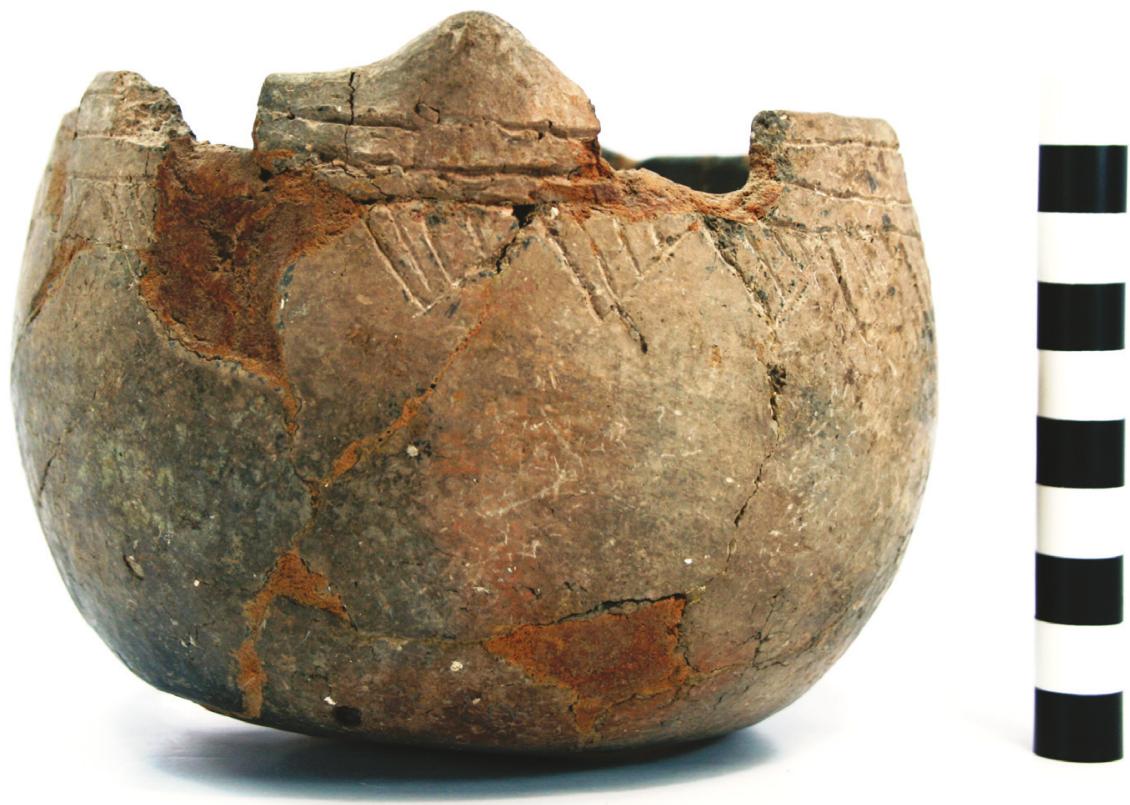

Figure 30. Sanders Incised bowl in Burial B-6 at the T. M. Sanders site (41LR2).

ESTIMATED VOLUME (IN

LITERS): 0.55

DECORATION (INCLUDING MOTIF AND ELEMENTS WHEN APPARENT): The rim has three horizontal incised lines, and there are 20 incised triangle elements pendant from the lowermost horizontal incised line. Each of the incised pendant triangles have three diagonal hatched lines within them (Figure 30).

PIGMENT USE AND LOCATION ON VESSEL: none

TYPE AND VARIETY (IF KNOWN): Sanders Incised 
SITE NAME OR SITE NUMBER: T. M. Sanders

VESSEL NO.: 338; Burial B-8

VESSEL FORM: Neckless Bottle

NON-PLASTICS AND PASTE: grog

RIM AND LIP FORM: Missing

CORE COLOR: $\mathrm{F}$ (fired in a reducing environment and cooled in the open air)

INTERIOR SURFACE COLOR: yellowish-brown; fire clouds on the body

EXTERIOR SURFACE COLOR: yellowish-brown; fire clouds on the body

WALL THICKNESS (IN MM): body, $6.5 \mathrm{~mm}$

INTERIOR SURFACE

TREATMENT: none

EXTERIOR SURFACE

TREATMENT: smoothed

HEIGHT (IN CM): 22.0+

ORIFICE DIAMETER (IN CM): N/A

DIAMETER AT BOTTOM OF RIM OR NECK (IN CM): N/A; maximum body

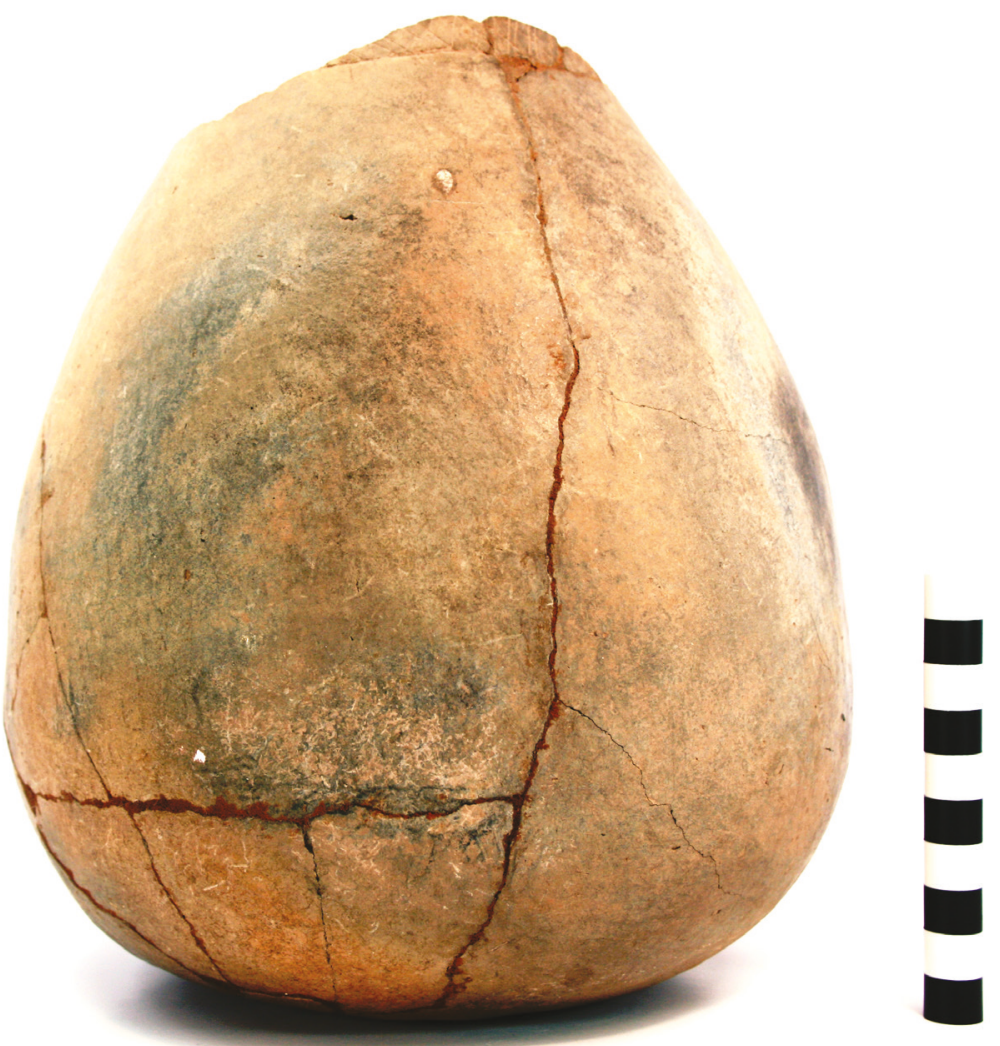

Figure 31. Sanders Engraved neckless bottle in Burial B-6 at the T. M. Sanders site (41LR2). diameter is $22.0 \mathrm{~cm}$

BASE DIAMETER (IN CM) AND SHAPE OF BASE: 12.5; circular and flat

ESTIMATED VOLUME (IN LITERS): 1.1+

DECORATION (INCLUDING MOTIF AND ELEMENTS WHEN APPARENT): A portion of one crosshatched engraved triangle element is present on the upper vessel body (Figure 31); there may have been four such triangle elements around the vessel.

PIGMENT USE AND LOCATION ON VESSEL: none

TYPE AND VARIETY (IF KNOWN): Sanders Engraved 
SITE NAME OR SITE NUMBER: T. M. Sanders

VESSEL NO.: 358, Burial B-9

VESSEL FORM: Bowl with scalloped/cut lip (Figure 32)

NON-PLASTICS AND PASTE: bone

RIM AND LIP FORM: Direct rim and rounded lip

CORE COLOR: F (fired in a reducing environment and cooled in the open air)

INTERIOR SURFACE COLOR: red

EXTERIOR SURFACE COLOR: red

WALL THICKNESS (IN MM): rim, $8.2 \mathrm{~mm}$

INTERIOR SURFACE

TREATMENT: smoothed

EXTERIOR SURFACE

TREATMENT: smoothed

HEIGHT (IN CM): 17.0

ORIFICE DIAMETER (IN CM): 42.0

DIAMETER AT BOTTOM OF

RIM OR NECK (IN CM): N/A

BASE DIAMETER (IN CM) AND SHAPE OF BASE: 15.0; circular and flat

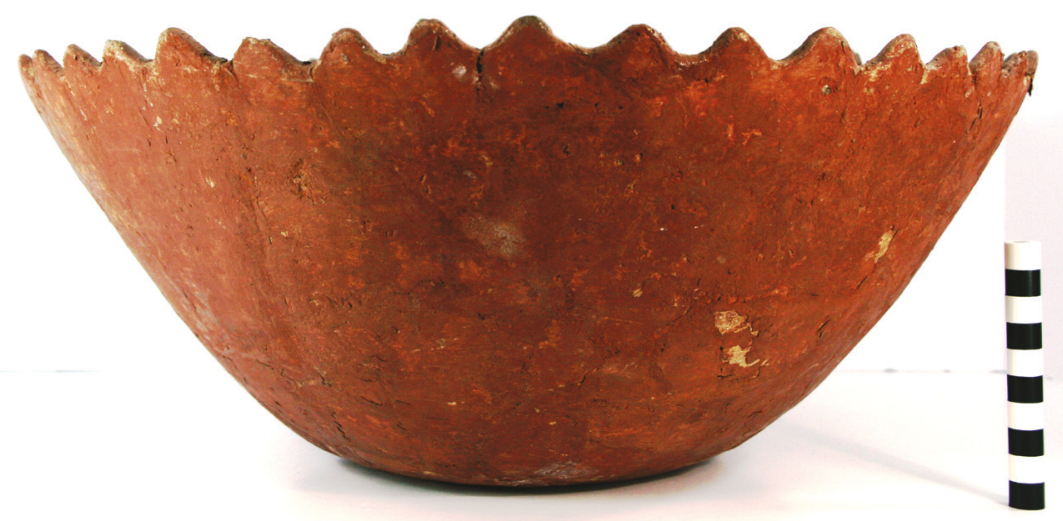

Figure 32. Sanders Slipped bowl in Burial B-9 at the T. M. Sanders site (41LR2).

ESTIMATED VOLUME (IN LITERS): 5.7

DECORATION (INCLUDING MOTIF AND ELEMENTS WHEN APPARENT): The interior and exterior surfaces of the vessel are red-slipped (Figure 32).

PIGMENT USE AND LOCATION ON VESSEL: none

TYPE AND VARIETY (IF KNOWN): Sanders Slipped 
SITE NAME OR SITE NUMBER: T. M. Sanders

VESSEL NO.: 359, Burial B-9

VESSEL FORM: Jar (Figure 33a)

NON-PLASTICS AND PASTE: grog

RIM AND LIP FORM: Everted rim and rounded lip

CORE COLOR: $\mathrm{F}$ (fired in a reducing environment and cooled in the open air)

INTERIOR SURFACE COLOR: red

EXTERIOR SURFACE COLOR: red

WALL THICKNESS (IN MM): rim, 5.9 mm

INTERIOR SURFACE TREATMENT: smoothed

EXTERIOR SURFACE TREATMENT:

burnished

HEIGHT (IN CM): 10.0

ORIFICE DIAMETER (IN CM): 17.7

DIAMETER AT BOTTOM OF RIM OR NECK (IN CM): 14.0

BASE DIAMETER (IN CM) AND SHAPE OF BASE: 9.5; circular and rounded

ESTIMATED VOLUME (IN LITERS): 1.1

DECORATION (INCLUDING MOTIF AND ELEMENTS WHEN APPARENT): The rim

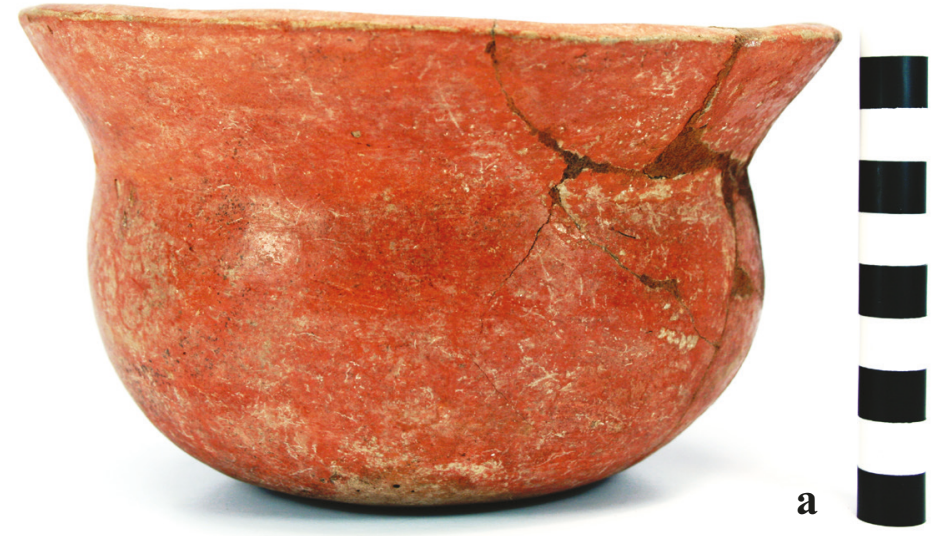

Figure 33. Sanders Engraved jar in Burial B-9 at the T. M. Sanders site (41LR2): a, side view; $b$, view of interior rim surface.

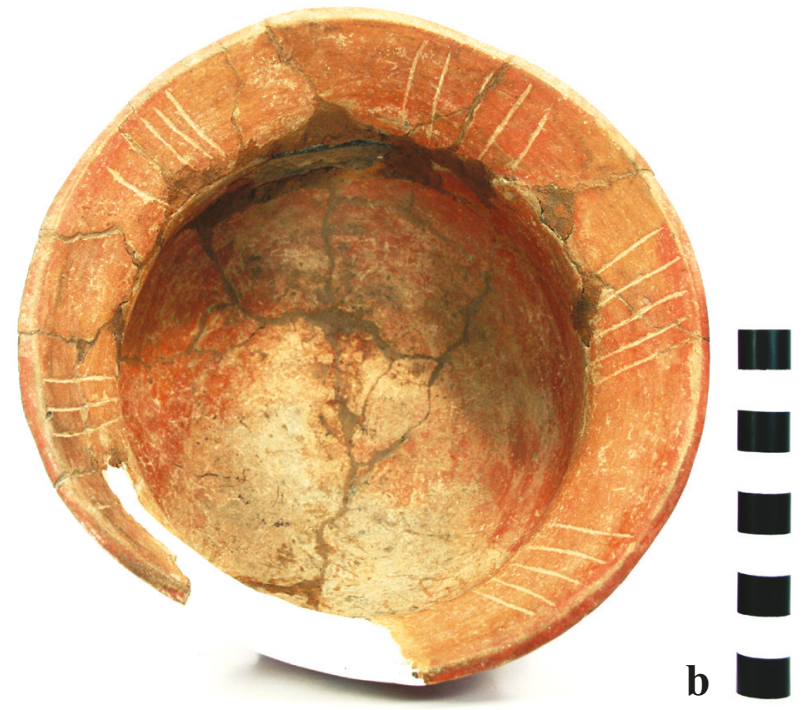

on the vessel's interior surface has six sets of five vertical engraved lines (Figure 33b).

PIGMENT USE AND LOCATION ON VESSEL: none

TYPE AND VARIETY (IF KNOWN): Sanders Engraved 
SITE NAME OR SITE NUMBER: T. M. Sanders

VESSEL NO.: 360, Burial B-9

VESSEL FORM: Carinated bowl

NON-PLASTICS AND PASTE: bone

RIM AND LIP FORM: Direct rim and rounded lip

CORE COLOR: $\mathrm{H}$ (fired in a reducing environment and cooled in the open air)

INTERIOR SURFACE COLOR: yellowish-brown; fire clouds on the rim and body

EXTERIOR SURFACE COLOR: very dark grayish-brown; fire clouds on the rim, body, and base

WALL THICKNESS (IN MM): rim, $6.7 \mathrm{~mm}$

INTERIOR SURFACE

TREATMENT: smoothed

EXTERIOR SURFACE

TREATMENT: burnished

HEIGHT (IN CM): 8.9

ORIFICE DIAMETER (IN CM):

19.3

DIAMETER AT BOTTOM OF RIM

OR NECK (IN CM): 19.3

BASE DIAMETER (IN CM) AND

SHAPE OF BASE: 10.2, circular

and flat

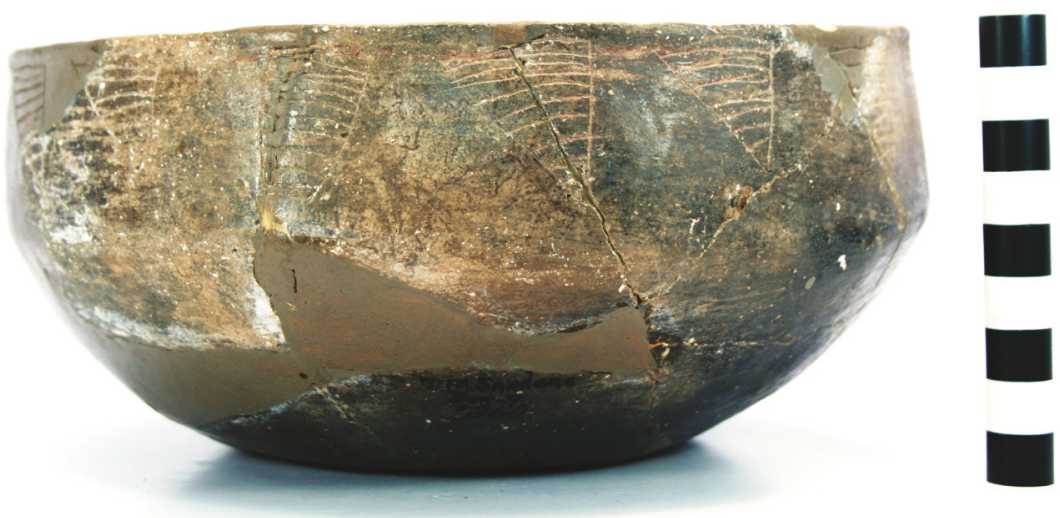

Figure 34. Sanders Engraved carinated bowl in Burial B-9 at the T. M. Sanders site (41LR2).

ESTIMATED VOLUME (IN LITERS): 1.0

DECORATION (INCLUDING MOTIF AND ELEMENTS WHEN APPARENT): The rim has 15 sets of engraved triangles with their apexes pointing towards the carination. Each of the engraved triangles is filled with five horizontal engraved lines (Figure 34).

PIGMENT USE AND LOCATION ON VESSEL: none

TYPE AND VARIETY (IF KNOWN): Sanders Engraved 
SITE NAME OR SITE NUMBER: T. M. Sanders

VESSEL NO.: 361, Burial B-9

VESSEL FORM: Bowl

NON-PLASTICS AND PASTE: grog and bone

RIM AND LIP FORM: Everted rim and scalloped/cut lip; lip notched

CORE COLOR: $\mathrm{F}$ (fired in a reducing environment and cooled in the open air)

INTERIOR SURFACE COLOR: yellowish-brown; fire clouds on the base

EXTERIOR SURFACE COLOR: yellowish-brown; fire clouds on the base

WALL THICKNESS (IN MM): rim, 8.6 mm

INTERIOR SURFACE

TREATMENT: smoothed

EXTERIOR SURFACE

TREATMENT: smoothed

HEIGHT (IN CM): 13.8

ORIFICE DIAMETER (IN CM):

40.0

DIAMETER AT BOTTOM OF RIM

OR NECK (IN CM): N/A

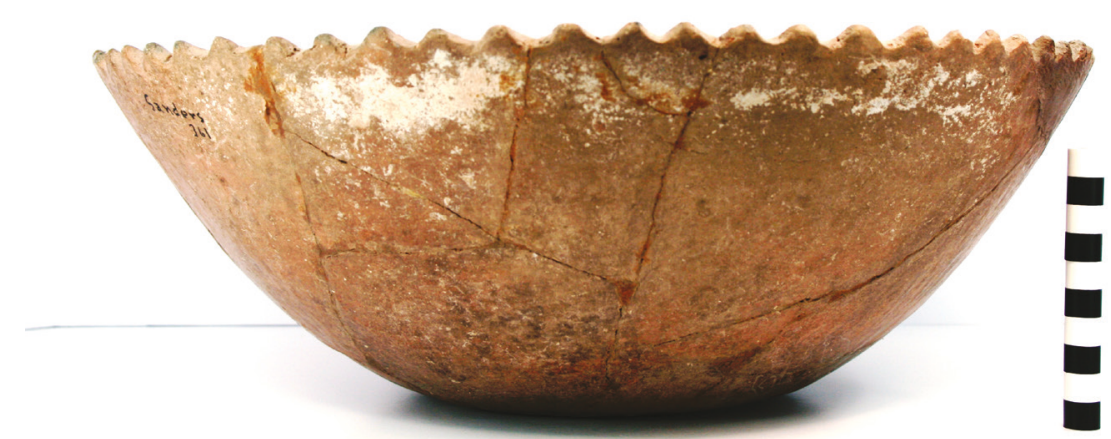

Figure 35. Bois d'Arc Plain, var. Crawford bowl in Burial B-9 at the T. M. Sanders site (41LR2).

BASE DIAMETER (IN CM) AND

SHAPE OF BASE: 15.0; circular and flat

ESTIMATED VOLUME (IN LITERS): 4.9

DECORATION (INCLUDING MOTIF AND ELEMENTS WHEN APPARENT): Plain (Figure 35)

PIGMENT USE AND LOCATION ON VESSEL: none

TYPE AND VARIETY (IF KNOWN): Bois d'Arc Plain, var. Crawford 
SITE NAME OR SITE NUMBER: T. M. Sanders

VESSEL NO.: 362, Burial B-9

VESSEL FORM: Bottle with a tapered neck

NON-PLASTICS AND PASTE: grog and bone

RIM AND LIP FORM: Direct rim and rounded lip

CORE COLOR: $\mathrm{F}$ (fired in a reducing environment and cooled in the open air)

INTERIOR SURFACE COLOR: red

EXTERIOR SURFACE COLOR: red

WALL THICKNESS (IN MM): rim, 5.9 mm

INTERIOR SURFACE TREATMENT: none

EXTERIOR SURFACE TREATMENT:

smoothed

HEIGHT (IN CM): 28.0

ORIFICE DIAMETER (IN CM): 4.2

DIAMETER AT BOTTOM OF RIM OR NECK (IN CM): 5.8; maximum body diameter is 16.8 $\mathrm{cm}$

BASE DIAMETER (IN CM) AND SHAPE OF BASE: 12.0 ; circular and rounded

ESTIMATED VOLUME (IN LITERS): 1.3

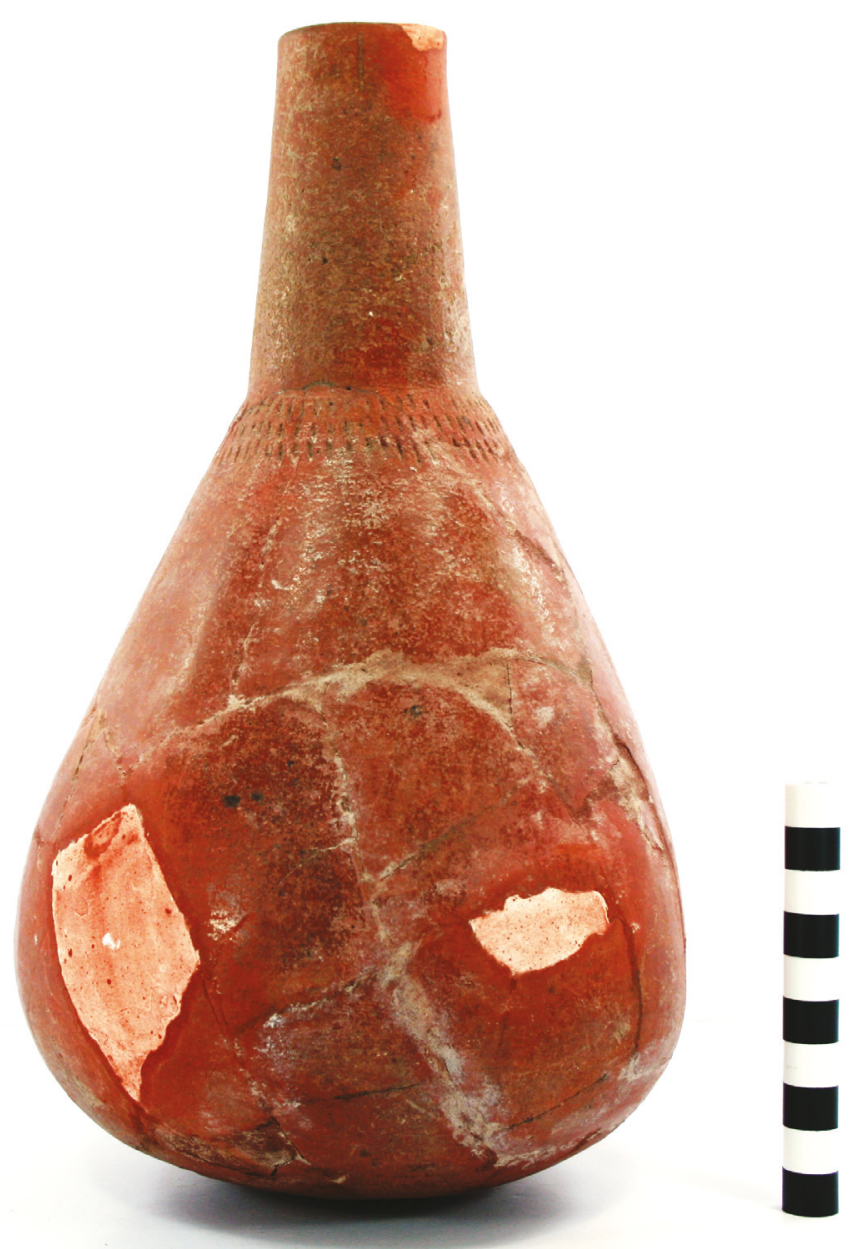

Figure 36. Maxey Noded Redware bottle in Burial B-9 at the T. M. Sanders site (41LR2).

DECORATION (INCLUDING MOTIF AND ELEMENTS WHEN APPARENT): The exterior surface and interior neck of the vessel have a red slip. There are also three rows of horizontal linear tool punctations on the vessel body immediately below the base of the neck (Figure 36).

PIGMENT USE AND LOCATION ON VESSEL: none

TYPE AND VARIETY (IF KNOWN): Maxey Noded Redware 
SITE NAME OR SITE NUMBER: T. M. Sanders

VESSEL NO.: 363, Burial B-9

VESSEL FORM: Jar

NON-PLASTICS AND PASTE: grog and bone

RIM AND LIP FORM: Direct rim and rounded lip

CORE COLOR: $\mathrm{G}$ (fired in a reducing environment and cooled in the open air)

INTERIOR SURFACE COLOR: grayish-brown; fire clouds on the body and base

EXTERIOR SURFACE COLOR: brown; fire clouds on the body and base

WALL THICKNESS (IN MM): rim, $8.1 \mathrm{~mm}$

INTERIOR SURFACE TREATMENT: smoothed

EXTERIOR SURFACE TREATMENT: smoothed on the body

HEIGHT (IN CM): 33.8

ORIFICE DIAMETER (IN CM): 24.0

DIAMETER AT BOTTOM OF RIM OR NECK (IN CM): 24.0

BASE DIAMETER (IN CM) AND SHAPE OF

BASE: 11.8; circular and flat

ESTIMATED VOLUME (IN LITERS): 10.5

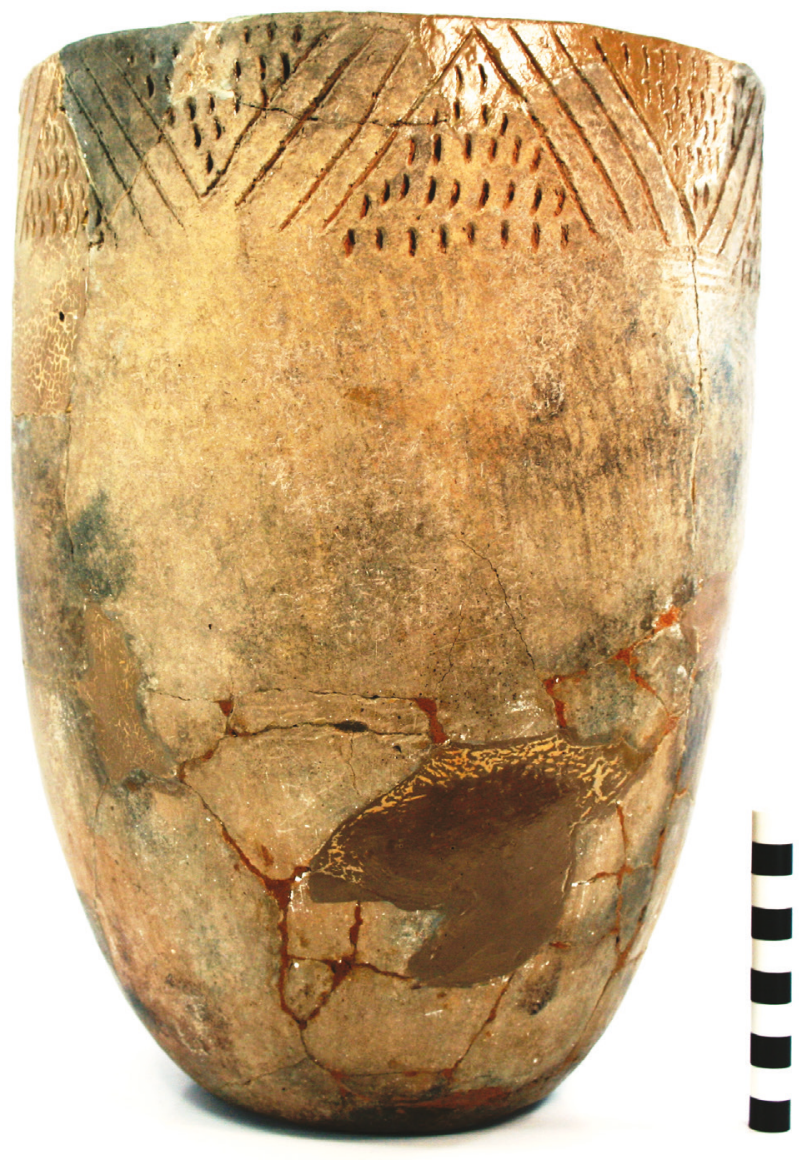

Figure 37. Canton Incised jar in Burial B-9 at the T. M. Sanders site (41LR2).

DECORATION (INCLUDING MOTIF AND ELEMENTS WHEN APPARENT): The rim has 12 incised triangle elements (with four sets of diagonal incised lines on either side) that alternate the orientation of their apex, either pointing towards the lip or pointing towards the vessel rim-body juncture. Each of the incised triangles is filled with rows of fingernail punctations (Figure 37).

PIGMENT USE AND LOCATION ON VESSEL: none

TYPE AND VARIETY (IF KNOWN): Canton Incised (see Suhm and Jelks 1962:Plate 12d) 
SITE NAME OR SITE NUMBER: T. M. Sanders

VESSEL NO.: 364, Burial B-9

VESSEL FORM: Bowl

NON-PLASTICS AND PASTE: grog

RIM AND LIP FORM: Direct rim and rounded lip

CORE COLOR: F (fired in a reducing environment and cooled in the open air)

INTERIOR SURFACE COLOR: reddish-brown; fire clouds on the rim and body

EXTERIOR SURFACE COLOR:

brown; fire clouds on the rim, body, and base

WALL THICKNESS (IN MM):

rim, $5.5 \mathrm{~mm}$

INTERIOR SURFACE

TREATMENT: smoothed

EXTERIOR SURFACE

TREATMENT: burnished

HEIGHT (IN CM): 8.0

ORIFICE DIAMETER (IN CM):

13.0

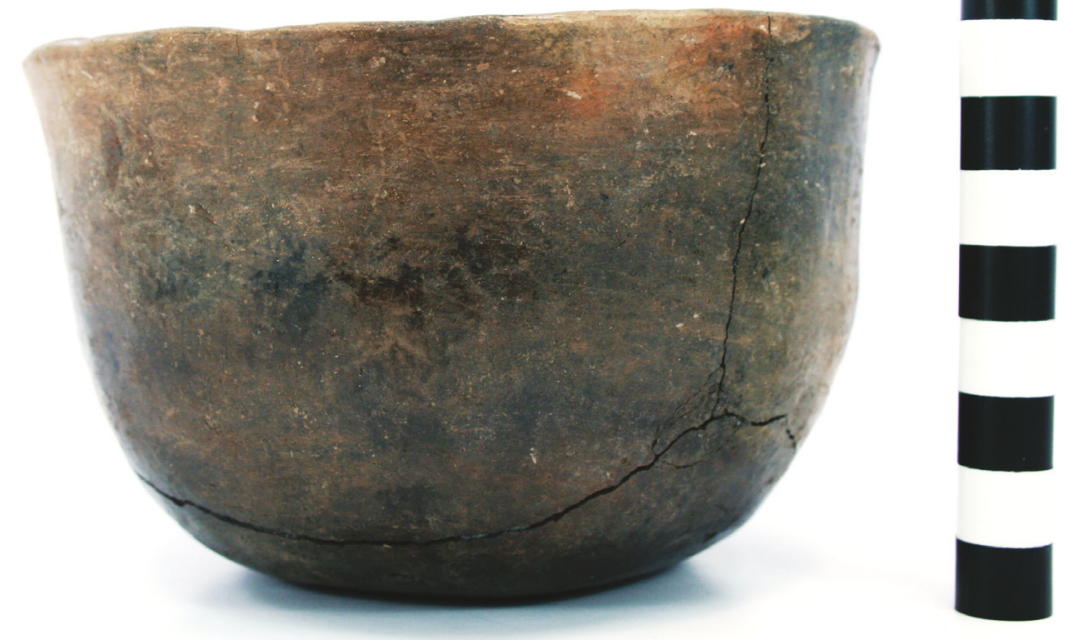

Figure 38. Bois d'Arc Plain bowl in Burial B-9 at the T. M.

DIAMETER AT BOTTOM OF

RIM OR NECK (IN CM): N/A

Sanders site (41LR2).

BASE DIAMETER (IN CM) AND SHAPE OF BASE: 7.8; circular and flat

ESTIMATED VOLUME (IN LITERS): 0.42

DECORATION (INCLUDING MOTIF AND ELEMENTS WHEN APPARENT): Plain (Figure 38)

PIGMENT USE AND LOCATION ON VESSEL: none

TYPE AND VARIETY (IF KNOWN): Bois d'Arc Plain 
SITE NAME OR SITE NUMBER: T. M. Sanders

VESSEL NO.: 370, Burial B-11

VESSEL FORM: Carinated bowl

NON-PLASTICS AND PASTE: grog

RIM AND LIP FORM: Direct rim and rounded lip

CORE COLOR: B (fired and cooled in a reducing environment)

INTERIOR SURFACE COLOR: dark grayish-brown; fire clouds on the body and base

EXTERIOR SURFACE COLOR: dark grayish-brown; fire clouds on the rim and body

WALL THICKNESS (IN MM): rim, $6.0 \mathrm{~mm}$

INTERIOR SURFACE

TREATMENT: smoothed

EXTERIOR SURFACE

TREATMENT: burnished

HEIGHT (IN CM): 16.0

ORIFICE DIAMETER (IN CM): 27.8

DIAMETER AT BOTTOM OF RIM

OR NECK (IN CM): 27.5

BASE DIAMETER (IN CM) AND

SHAPE OF BASE: 12.0; circular and

flat

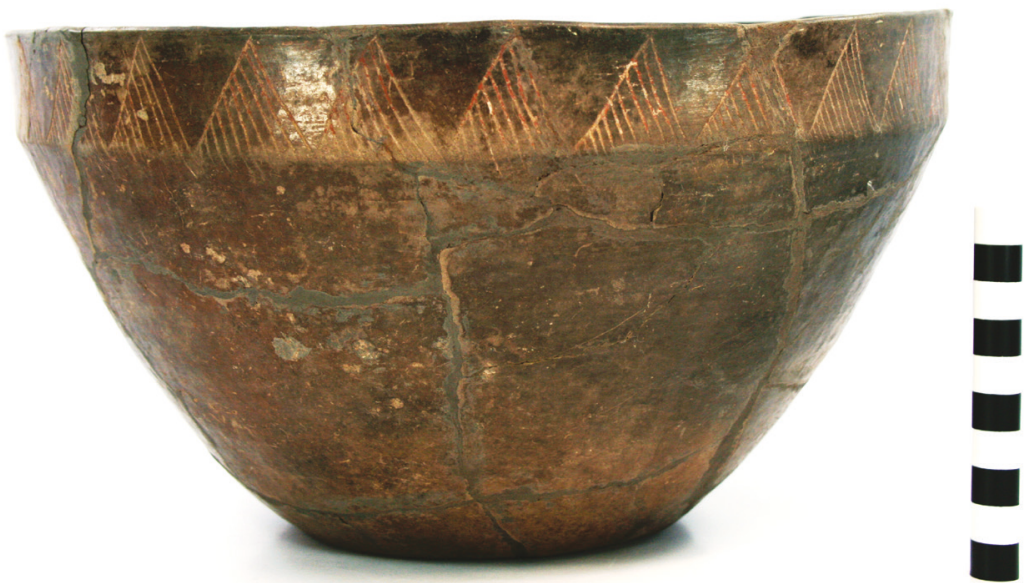

Figure 39. Sanders Engraved carinated bowl in Burial B-11 at the T. M. Sanders site (41LR2).

ESTIMATED VOLUME (IN LITERS): 4.0

DECORATION (INCLUDING MOTIF AND ELEMENTS WHEN APPARENT): The rim is decorated with 29 engraved pendant triangles whose apexes touch the bottom of the vessel lip. Each engraved triangle is filled with diagonal engraved hatched lines (Figure 39).

PIGMENT USE AND LOCATION ON VESSEL: red pigment in engraved lines TYPE AND VARIETY (IF KNOWN): Sanders Engraved (see Suhm and Jelks 1962:Plate 69i) 
SITE NAME OR SITE NUMBER: T. M. Sanders

VESSEL NO.: 371, Burial B-11

VESSEL FORM: Carinated bowl

NON-PLASTICS AND PASTE: grog

RIM AND LIP FORM: Direct rim and flat lip

CORE COLOR: F (fired in a reducing environment and cooled in the open air)

INTERIOR SURFACE COLOR: yellowish-brown; fire clouds on the body

EXTERIOR SURFACE COLOR: yellowish-brown; fire clouds on the rim and body

WALL THICKNESS (IN MM):

rim, $6.2 \mathrm{~mm}$; body, $7.9 \mathrm{~mm}$

INTERIOR SURFACE

TREATMENT: smoothed

EXTERIOR SURFACE

TREATMENT: smoothed

HEIGHT (IN CM): 15.8

ORIFICE DIAMETER (IN

CM): 38.1

DIAMETER AT BOTTOM OF

RIM OR NECK (IN CM): 38.1

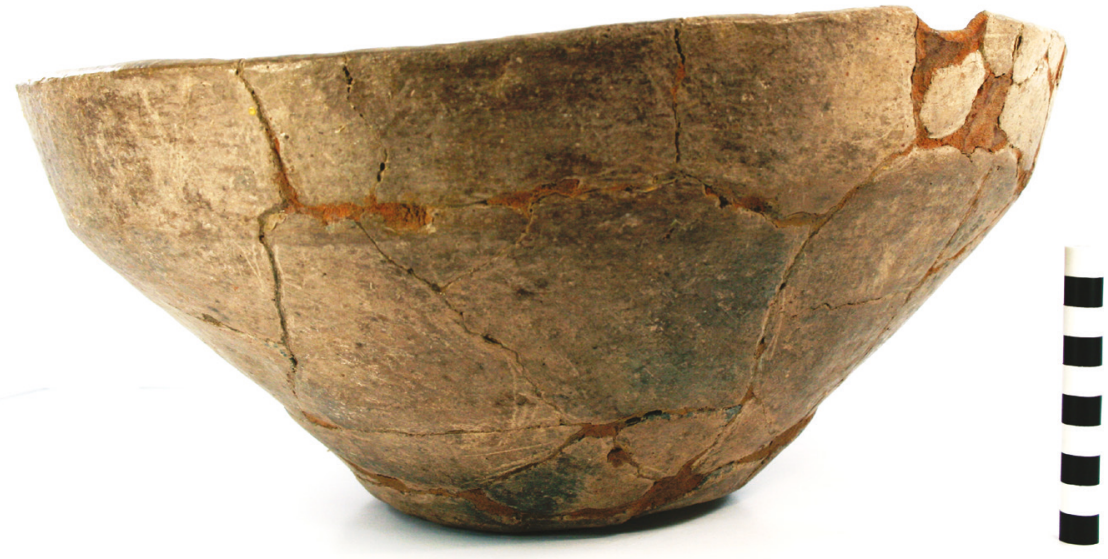

Figure 40. Bois d'Arc Plain carinated bowl in Burial B-11 at the T. M. Sanders site (41LR2).

BASE DIAMETER (IN CM) AND

SHAPE OF BASE: 14.0; circular and flat

ESTIMATED VOLUME (IN LITERS): 5.5

DECORATION (INCLUDING MOTIF AND ELEMENTS WHEN APPARENT): Plain (Figure 40)

PIGMENT USE AND LOCATION ON VESSEL: none

TYPE AND VARIETY (IF KNOWN): Bois d'Arc Plain 
SITE NAME OR SITE NUMBER: T. M. Sanders

VESSEL NO.: 372A, Burial B-11

VESSEL FORM: Olla

NON-PLASTICS AND PASTE: shell

RIM AND LIP FORM: Direct rim and rounded, exterior folded lip

CORE COLOR: $\mathrm{G}$ (fired in a reducing environment and cooled in the open air)

INTERIOR SURFACE COLOR: dark grayish-brown

EXTERIOR SURFACE COLOR: yellowish-brown; fire clouds on the body

WALL THICKNESS (IN MM): rim,

$7.6 \mathrm{~mm}$

INTERIOR SURFACE

TREATMENT: none

EXTERIOR SURFACE

TREATMENT: smoothed

HEIGHT (IN CM): N/A

ORIFICE DIAMETER (IN CM):

12.1

DIAMETER AT BOTTOM OF RIM

OR NECK (IN CM): 10.2

BASE DIAMETER (IN CM) AND

SHAPE OF BASE: N/A

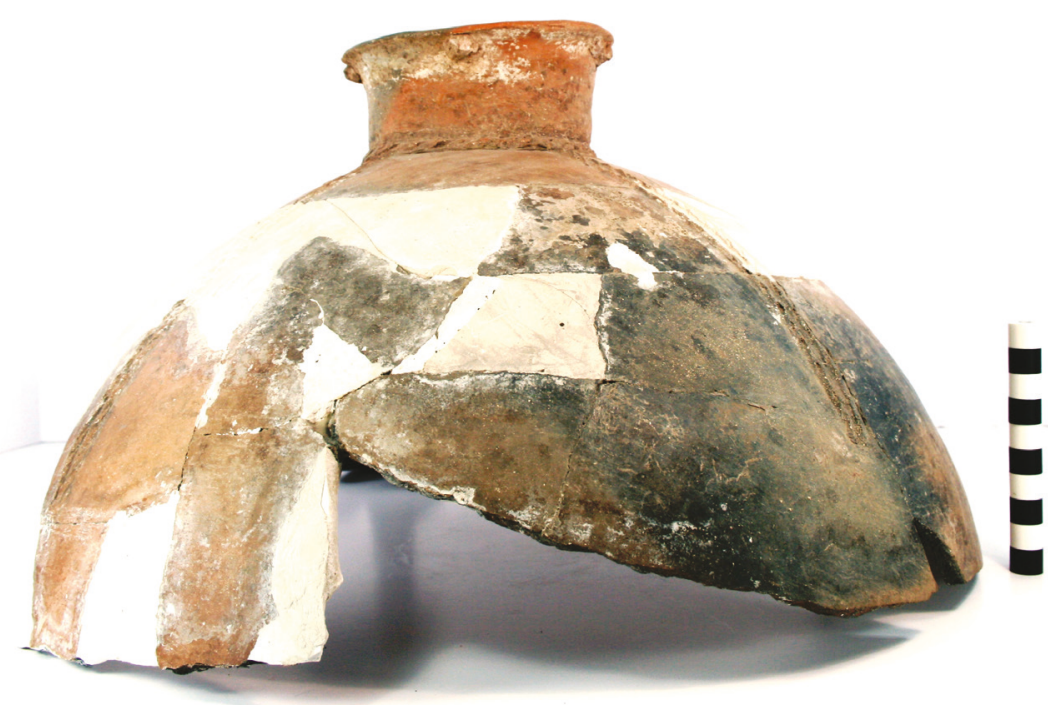

Figure 41. Appliqued olla in Burial B-11 at the T. M. Sanders site.

ESTIMATED VOLUME (IN LITERS): N/A

DECORATION (INCLUDING MOTIF AND ELEMENTS WHEN APPARENT): There are four appliqued nodes on the rim under the vessel lip, along with a horizontal appliqued fillet at the base of the neck. The vessel body has four vertical columns of two appliqued fillets (Figure 41).

PIGMENT USE AND LOCATION ON VESSEL: none

TYPE AND VARIETY (IF KNOWN): Unidentified utility ware 
SITE NAME OR SITE NUMBER: T. M. Sanders

VESSEL NO.: 372, Burial B-11

VESSEL FORM: Carinated bowl

NON-PLASTICS AND PASTE: grog

RIM AND LIP FORM: Direct rim and rounded lip; lip notched

CORE COLOR: F (fired in a reducing environment and cooled in the open air)

INTERIOR SURFACE COLOR: dark yellowish-brown; fire clouds on the body

EXTERIOR SURFACE COLOR: dark yellowish-brown; fire clouds on the body and base

WALL THICKNESS (IN MM):

rim, $5.8 \mathrm{~mm}$

INTERIOR SURFACE

TREATMENT: smoothed

EXTERIOR SURFACE

TREATMENT: burnished

HEIGHT (IN CM): 14.7

ORIFICE DIAMETER (IN

$\mathrm{CM}): 36.6$

DIAMETER AT BOTTOM OF

RIM OR NECK (IN CM): 36.6

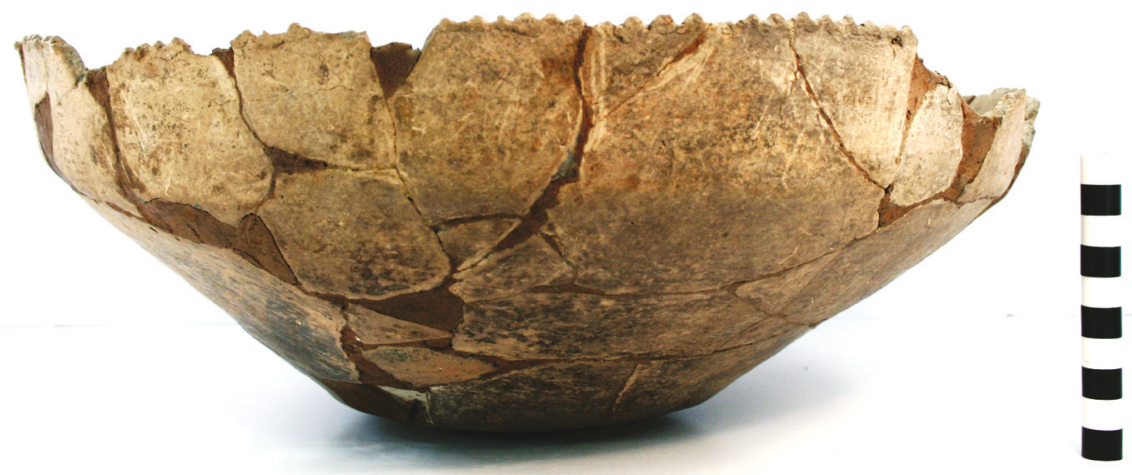

Figure 42. Bois d'Arc Plain, var. Crawford carinated bowl in Burial B-11 at the T. M. Sanders site (41LR2).

BASE DIAMETER (IN CM) AND SHAPE OF BASE: 11.5; circular and flat

ESTIMATED VOLUME (IN LITERS):4.8

DECORATION (INCLUDING MOTIF AND ELEMENTS WHEN APPARENT): Plain (Figure 42)

PIGMENT USE AND LOCATION ON VESSEL: none

TYPE AND VARIETY (IF KNOWN): Bois d'Arc Plain, var. Crawford 
SITE NAME OR SITE NUMBER: T. M. Sanders

VESSEL NO.: 373, Burial B-12

VESSEL FORM: Bottle with three lobes and connecting horizontal ceramic column (Figure 43)

NON-PLASTICS AND PASTE: grog

RIM AND LIP FORM: Direct rim and rounded lip

CORE COLOR: $\mathrm{F}$ (fired in a reducing environment and cooled in the open air)

INTERIOR SURFACE COLOR: red

EXTERIOR SURFACE COLOR: red

WALL THICKNESS (IN MM): rim, $5.8 \mathrm{~mm}$

INTERIOR SURFACE TREATMENT: none

EXTERIOR SURFACE TREATMENT: burnished

HEIGHT (IN CM): 19.7

ORIFICE DIAMETER (IN CM): 3.7

DIAMETER AT BOTTOM OF RIM OR NECK (IN

$\mathrm{CM})$ : 3.7 ; lower lobe is $6.7 \mathrm{~cm}$ in diameter; upper lobe is $3.6 \mathrm{~cm}$ in diameter

BASE DIAMETER (IN CM) AND SHAPE OF BASE: 4.0

ESTIMATED VOLUME (IN LITERS): 0.3

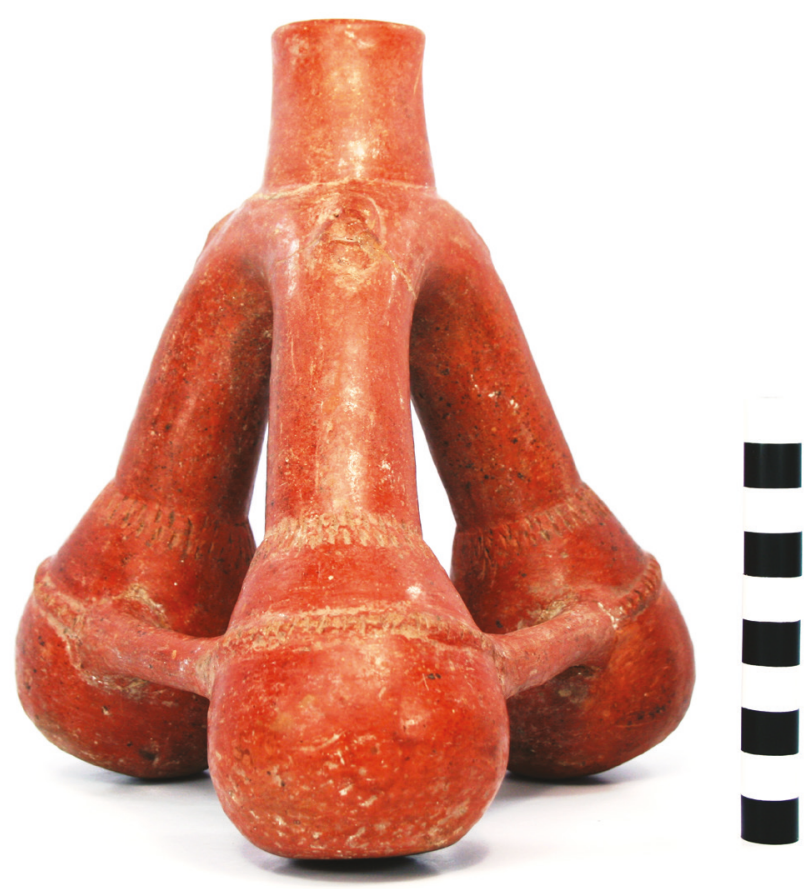

Figure 43. Maxey Noded Redware tri-lobed bottle in Burial B-12 at the T. M. Sanders site (41LR2).

DECORATION (INCLUDING MOTIF AND ELEMENTS WHEN APPARENT): The exterior and interior neck surfaces have a red slip. The upper lobe of the bottle is decorated with three appliqued nodes; each of the nodes have a face with marked eyes and mouth. The upper part of the lower lobe has two rows of tool punctations. The mid-part of the lower lobe has a single horizontal appliqued fillet that encircles 50 percent of the lobe (Figure 43).

PIGMENT USE AND LOCATION ON VESSEL: none

TYPE AND VARIETY (IF KNOWN): Maxey Noded Redware 
SITE NAME OR SITE NUMBER: T. M. Sanders

VESSEL NO.: 374, Burial B-12

VESSEL FORM: Bowl with scalloped/cut lip

NON-PLASTICS AND PASTE: grog and bone

RIM AND LIP FORM: Direct rim and rounded lip; interior thickened rim

CORE COLOR: F (fired in a reducing environment and cooled in the open air)

INTERIOR SURFACE COLOR: dark yellowish-brown; fire clouds on the rim, body, and base

EXTERIOR SURFACE COLOR: yellowish-brown; fire clouds on the rim, body, and base

WALL THICKNESS (IN

$\mathrm{MM})$ : rim, $7.0 \mathrm{~mm}$

INTERIOR SURFACE

TREATMENT: smoothed

EXTERIOR SURFACE

TREATMENT: smoothed

HEIGHT (IN CM): 6.4

ORIFICE DIAMETER (IN

CM): 15.8

DIAMETER AT BOTTOM OF RIM OR NECK (IN CM): $\mathrm{N} / \mathrm{A}$

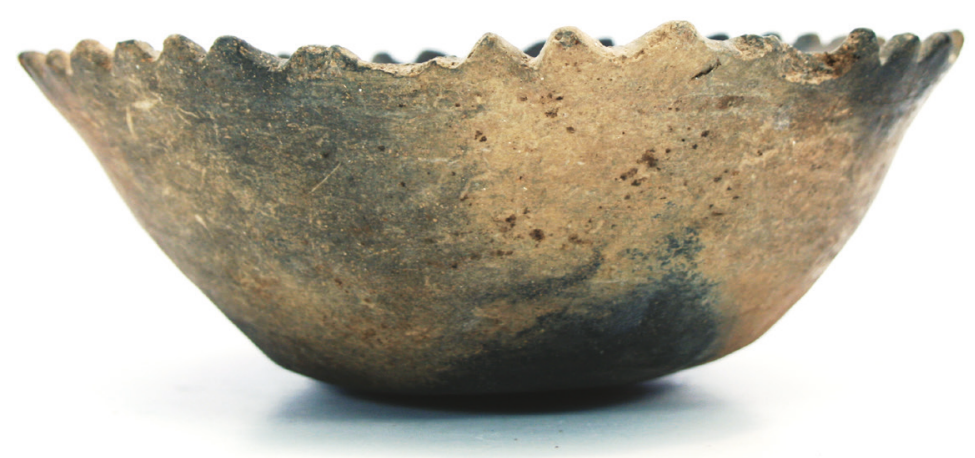

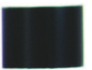

Figure 44. Bois d'Arc Plain, var. Crawford bowl in Burial B-12 at the T. M. Sanders site (41LR2).

BASE DIAMETER (IN CM) AND SHAPE OF BASE: 7.6; circular and rounded

ESTIMATED VOLUME (IN LITERS): 0.4

DECORATION (INCLUDING MOTIF AND ELEMENTS WHEN APPARENT): Plain (Figure 44)

PIGMENT USE AND LOCATION ON VESSEL: none

TYPE AND VARIETY (IF KNOWN): Bois d'Arc Plain, var. Crawford 
SITE NAME OR SITE NUMBER: T. M. Sanders

VESSEL NO.: 375, Burial B-12

VESSEL FORM: Carinated bowl

NON-PLASTICS AND PASTE: grog

RIM AND LIP FORM: Inverted rim and rounded lip

CORE COLOR: $\mathrm{G}$ (fired in a reducing environment and cooled in the open air)

INTERIOR SURFACE COLOR: very dark grayish-brown

EXTERIOR SURFACE COLOR: dark reddish-brown; fire clouds on the rim, body, and base

WALL THICKNESS (IN MM): rim, $6.7 \mathrm{~mm}$

INTERIOR SURFACE

TREATMENT: smoothed

EXTERIOR SURFACE

TREATMENT: smoothed

HEIGHT (IN CM): 14.0

ORIFICE DIAMETER (IN

CM): 29.0

DIAMETER AT BOTTOM OF RIM OR NECK (IN CM): 31.3

BASE DIAMETER (IN CM)

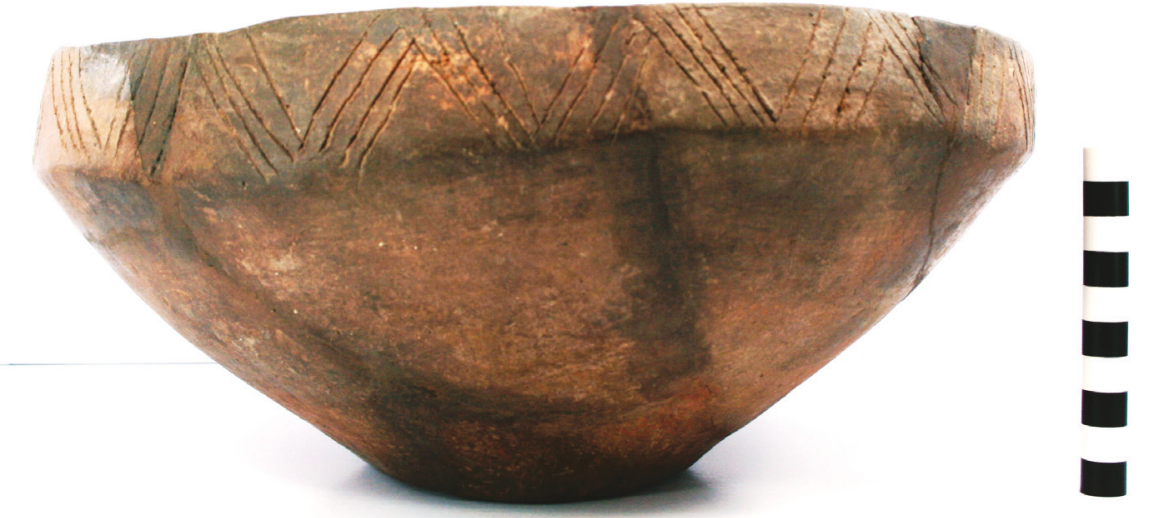

Figure 45. Sanders Incised carinated bowl in Burial B-12 at the T. M. Sanders site (41LR2).

AND SHAPE OF BASE: 11.5;

circular and flat

ESTIMATED VOLUME (IN LITERS): 2.4

DECORATION (INCLUDING MOTIF AND ELEMENTS WHEN APPARENT): The rim is decorated with 13 sets of incised diagonal opposed triangular elements. Each triangle is defined by two sets of four diagonal opposed incised lines (Figure 45).

PIGMENT USE AND LOCATION ON VESSEL: none

TYPE AND VARIETY (IF KNOWN): Sanders Incised 
SITE NAME OR SITE NUMBER: T. M. Sanders

VESSEL NO.: 376, Burial B-12

VESSEL FORM: Jar with two strap handles (39 x $18 \mathrm{~mm}$ in height and width) (Figure 46)

NON-PLASTICS AND PASTE: grog

RIM AND LIP FORM: Direct rim and rounded lip

CORE COLOR: F (fired in a reducing environment and cooled in the open air)

INTERIOR SURFACE COLOR: dark brown; fire clouds on the rim and body

EXTERIOR SURFACE COLOR: dark brown; fire clouds on the rim and body

WALL THICKNESS (IN MM): rim, 6.9 $\mathrm{mm}$

INTERIOR SURFACE TREATMENT:

smoothed

EXTERIOR SURFACE TREATMENT: none

HEIGHT (IN CM): 10.6

ORIFICE DIAMETER (IN CM): 9.7

DIAMETER AT BOTTOM OF RIM OR NECK (IN CM): 9.7

BASE DIAMETER (IN CM) AND

SHAPE OF BASE: 5.7; circular and flat



Figure 46. cf. Monkstown Fingernail Impressed jar in Burial B-12 at the T. M. Sanders site (41LR2).

ESTIMATED VOLUME (IN LITERS): 0.62

DECORATION (INCLUDING MOTIF AND ELEMENTS WHEN APPARENT): The rim is decorated with a single row of horizontal pinching, while the body of the vessel has two horizontal pinched rows and two pinched concentric circle elements that are divided by seven vertical rows of pinching. The strap handles each have four horizontal pinched rows (Figure 46).

PIGMENT USE AND LOCATION ON VESSEL: none

TYPE AND VARIETY (IF KNOWN): cf. Monkstown Fingernail Impressed 
SITE NAME OR SITE NUMBER: T. M. Sanders

VESSEL NO.: 377, Burial B-12

VESSEL FORM: Carinated bowl

NON-PLASTICS AND PASTE: grog

RIM AND LIP FORM: Inverted rim and rounded lip

CORE COLOR: F (fired in a reducing environment and cooled in the open air)

INTERIOR SURFACE COLOR: reddish-brown; fire clouds on the lower body and base

EXTERIOR SURFACE COLOR:

reddish-brown; fire clouds on the body and base

WALL THICKNESS (IN MM): rim, 6.0 $\mathrm{mm}$

INTERIOR SURFACE TREATMENT: smoothed

EXTERIOR SURFACE TREATMENT: burnished on the body

HEIGHT (IN CM): 14.2

Figure 47. Sanders Incised carinated bowl in Burial B-12 at the T. M. Sanders site (41LR2).

ORIFICE DIAMETER (IN CM): 27.5

DIAMETER AT BOTTOM OF RIM OR NECK (IN CM): 29.0

BASE DIAMETER (IN CM) AND SHAPE OF BASE: 10.9; circular and flat

ESTIMATED VOLUME (IN LITERS): 2.3

DECORATION (INCLUDING MOTIF AND ELEMENTS WHEN APPARENT): The rim panel has a series of 21 alternating incised triangle elements filled with diagonal incised lines pitched in opposing directions (Figure 47).

PIGMENT USE AND LOCATION ON VESSEL: none

TYPE AND VARIETY (IF KNOWN): Sanders Incised 
SITE NAME OR SITE NUMBER: T. M. Sanders

VESSEL NO.: 378, Burial B-12

VESSEL FORM: Bottle

NON-PLASTICS AND PASTE: grog

RIM AND LIP FORM: N/A

CORE COLOR: $\mathrm{G}$ (fired in a reducing environment and cooled in the open air)

INTERIOR SURFACE COLOR: grayish-brown

EXTERIOR SURFACE COLOR: dark reddishbrown; fire clouds on the rim and body

WALL THICKNESS (IN MM): rim, $7.1 \mathrm{~mm}$

INTERIOR SURFACE TREATMENT: none

EXTERIOR SURFACE TREATMENT: burnished

HEIGHT (IN CM): 14.9+

ORIFICE DIAMETER (IN CM): 3.1

DIAMETER AT BOTTOM OF RIM OR NECK

(IN CM): 4.4; maximum body diameter is $8.3 \mathrm{~cm}$

BASE DIAMETER (IN CM) AND SHAPE OF

BASE: 5.7; circular and flat

ESTIMATED VOLUME (IN LITERS): 0.34+

DECORATION (INCLUDING MOTIF AND

ELEMENTS WHEN APPARENT): There are two large (18.5 $\mathrm{mm}$ in diameter) appliqued nodes on the vessel body that are connected by a single horizontal appliqued fillet (Figure 48).

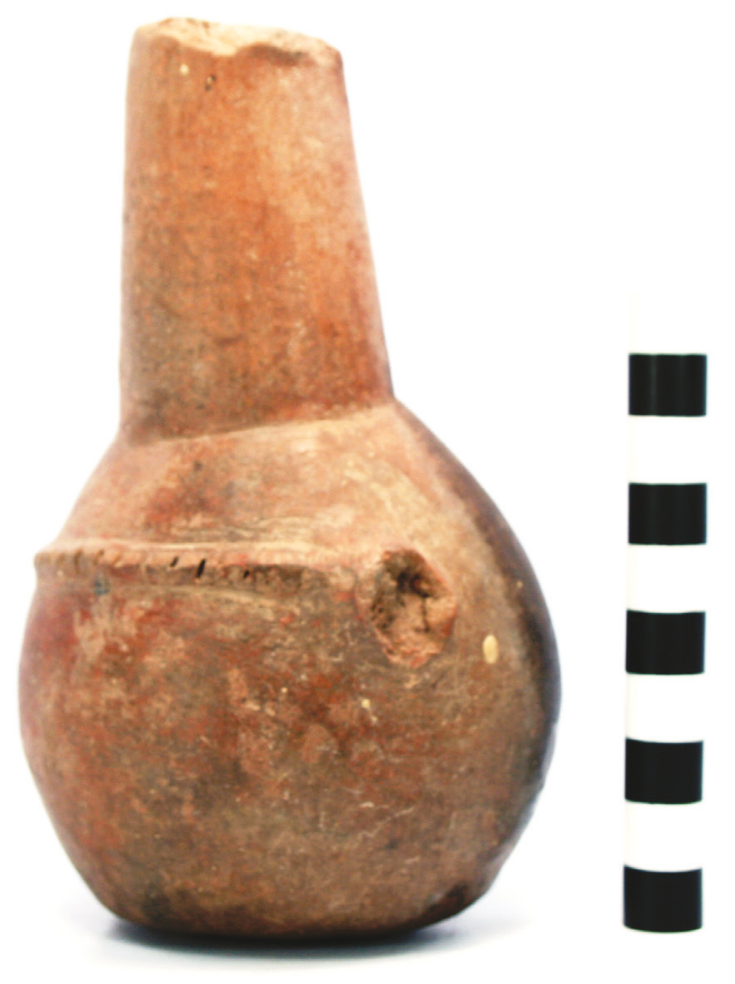

Figure 48. Appliqued bottle in Burial B-12 at the T. M. Sanders site (41LR2).

PIGMENT USE AND LOCATION ON VESSEL: none

TYPE AND VARIETY (IF KNOWN): Unidentified fine ware, cf. with a non-slipped Maxey Noded Redware vessel 
SITE NAME OR SITE NUMBER: T. M. Sanders

VESSEL NO.: 381, Burial B-13

VESSEL FORM: Bottle

NON-PLASTICS AND PASTE: grog

RIM AND LIP FORM: Direct rim and rounded lip

CORE COLOR: $\mathrm{F}$ (fired in a reducing environment and cooled in the open air)

INTERIOR SURFACE COLOR: reddish-brown

EXTERIOR SURFACE COLOR: red

WALL THICKNESS (IN MM): rim, $6.1 \mathrm{~mm}$

INTERIOR SURFACE TREATMENT: none

EXTERIOR SURFACE TREATMENT: burnished

HEIGHT (IN CM): 16.4

ORIFICE DIAMETER (IN CM): 3.1

DIAMETER AT BOTTOM OF RIM OR NECK

(IN CM): 4.1; maximum body diameter is $10.3 \mathrm{~cm}$

BASE DIAMETER (IN CM) AND SHAPE OF

BASE: $6.0 \mathrm{~cm}$; circular and flat

Figure 49. Maxey Noded Redware bottle in Burial B-13 at the T. $M$. Sanders site (41LR2).

ESTIMATED VOLUME (IN LITERS): 0.39

DECORATION (INCLUDING MOTIF AND ELEMENTS WHEN APPARENT): The exterior vessel surface has a red slip. There are also three vertical columns of three sets of appliqued nodes interspersed with linear tool punctations. Between the appliqued-punctated columns are three rows of linear tool punctations at the top of the vessel body (Figure 49).

PIGMENT USE AND LOCATION ON VESSEL: none

TYPE AND VARIETY (IF KNOWN): Maxey Noded Redware 
SITE NAME OR SITE NUMBER: T. M. Sanders

VESSEL NO.: 386, Burial B-13

VESSEL FORM: Bottle

NON-PLASTICS AND PASTE: grog

RIM AND LIP FORM: Direct rim and rounded lip

CORE COLOR: $\mathrm{F}$ (fired in a reducing

environment and cooled in the open air)

INTERIOR SURFACE COLOR: red

EXTERIOR SURFACE COLOR: red

WALL THICKNESS (IN MM): rim, $6.0 \mathrm{~mm}$

INTERIOR SURFACE TREATMENT: none

EXTERIOR SURFACE TREATMENT:

burnished

HEIGHT (IN CM): 15.0

ORIFICE DIAMETER (IN CM): 3.2

DIAMETER AT BOTTOM OF RIM OR

NECK (IN CM): 4.0; maximum body

diameter of $9.8 \mathrm{~cm}$

BASE DIAMETER (IN CM) AND SHAPE

OF BASE: 5.1; circular and rounded

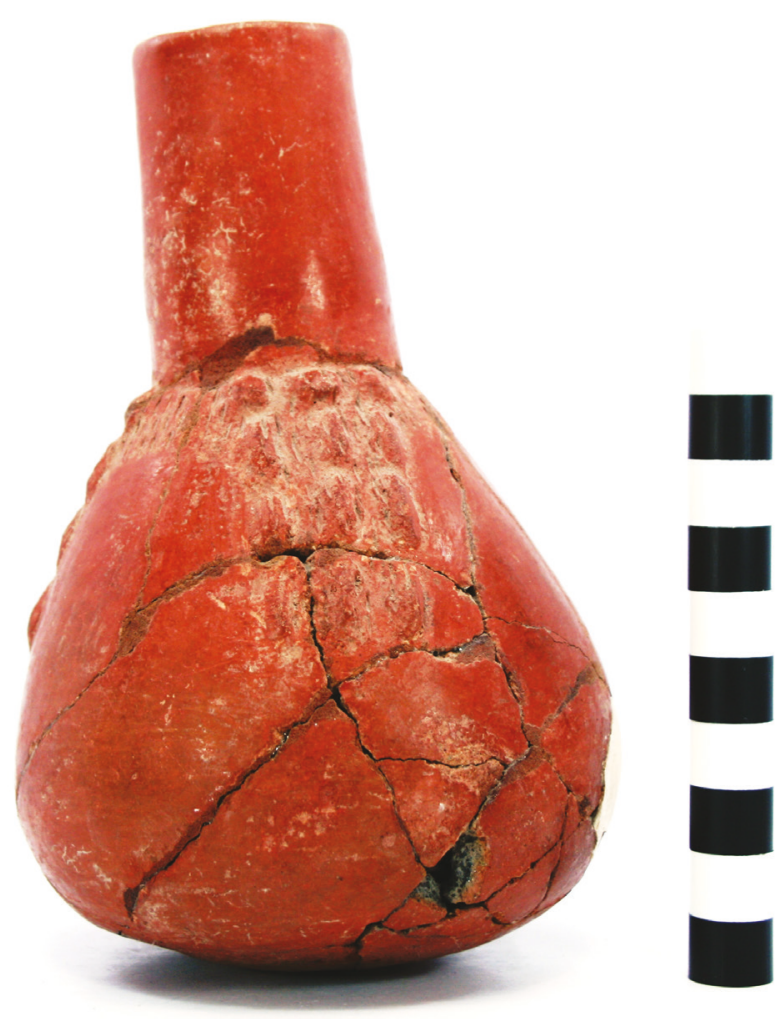

Figure 50. Maxey Noded Redware bottle in Burial B-13 at the T. M. Sanders site (41LR2).

ESTIMATED VOLUME (IN LITERS): 0.3

DECORATION (INCLUDING MOTIF AND ELEMENTS WHEN APPARENT): The exterior and interior neck surfaces of the vessel have a red slip. On the vessel body are three vertical columns of five appliqued nodes, and there are three rows of linear tool punctations between these nodes. Between the appliqued columns and at the top of the vessel body are two rows of linear tool punctations (Figure 50).

PIGMENT USE AND LOCATION ON VESSEL: none

TYPE AND VARIETY (IF KNOWN): Maxey Noded Redware 
SITE NAME OR SITE NUMBER: T. M. Sanders

VESSEL NO.: 387, Burial B-13

VESSEL FORM: Jar

NON-PLASTICS AND PASTE: grog

RIM AND LIP FORM: Direct rim and rounded lip

CORE COLOR: $\mathrm{G}$ (fired in a reducing environment and cooled in the open air)

INTERIOR SURFACE COLOR: dark grayishbrown

EXTERIOR SURFACE COLOR: dark reddishbrown

WALL THICKNESS (IN MM): rim, 6.0 mm

INTERIOR SURFACE TREATMENT: none

EXTERIOR SURFACE TREATMENT: smoothed on the body; organic residue on the body

HEIGHT (IN CM): 17.7

ORIFICE DIAMETER (IN CM): 14.7

DIAMETER AT BOTTOM OF RIM OR NECK (IN CM): 14.7

BASE DIAMETER (IN CM) AND SHAPE OF

BASE: 9.6; circular and flat

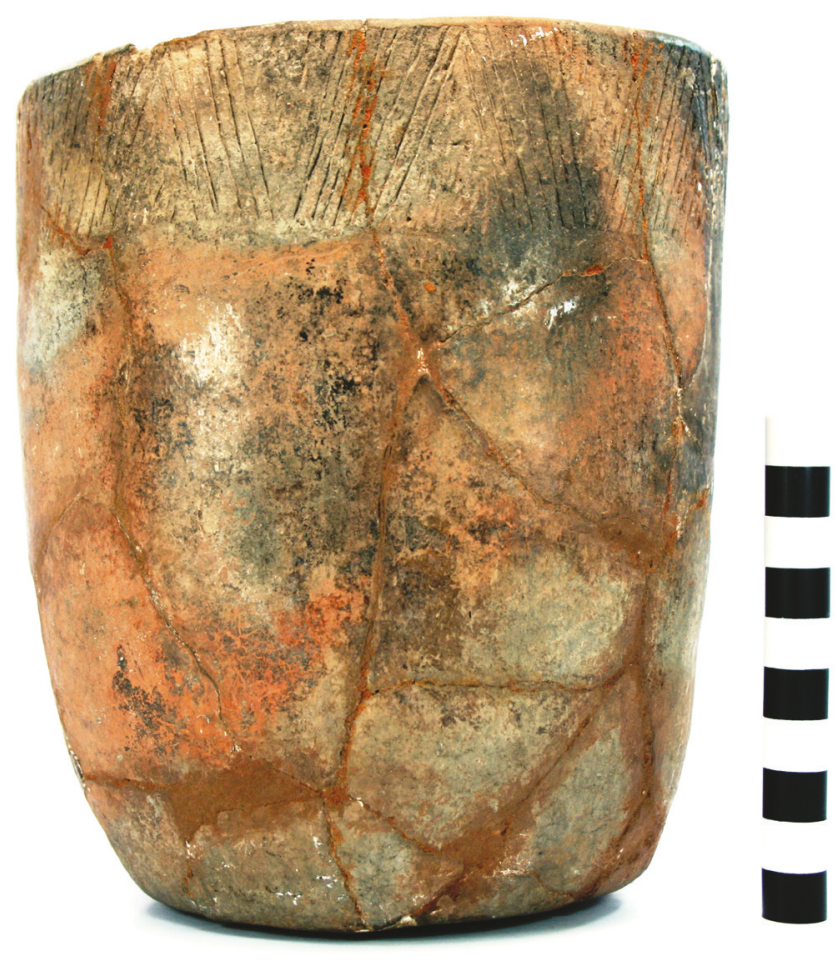

Figure 51. Canton Incised jar in Burial B-13 at the T. M. Sanders site (41LR2).

\section{ESTIMATED VOLUME (IN LITERS): 2.3}

DECORATION (INCLUDING MOTIF AND ELEMENTS WHEN APPARENT): The rim has 16 alternating incised triangle elements filled with rows of tool punctations. Each triangle element is defined by two sets of six diagonal incised lines pitched in opposite directions (Figure 51).

PIGMENT USE AND LOCATION ON VESSEL: none

TYPE AND VARIETY (IF KNOWN): Canton Incised 
SITE NAME OR SITE NUMBER: T. M. Sanders

VESSEL NO.: 398, Burial B-15

VESSEL FORM: Bowl with two lip tabs (17 x $24 \mathrm{~mm}$ in height and width) (Figure 52)

NON-PLASTICS AND PASTE: grog

RIM AND LIP FORM: Direct rim and rounded lip

CORE COLOR: F (fired in a reducing environment and cooled in the open air)

INTERIOR SURFACE COLOR: yellowish-brown; fire clouds on the rim, body, and base

EXTERIOR SURFACE COLOR: yellowish-brown; fire clouds on the body

WALL THICKNESS (IN

$\mathrm{MM})$ : rim, $5.1 \mathrm{~mm}$

INTERIOR SURFACE

TREATMENT: none

EXTERIOR SURFACE

TREATMENT: smoothed

HEIGHT (IN CM): 7.0

ORIFICE DIAMETER (IN

CM): 10.9

DIAMETER AT BOTTOM

OF RIM OR NECK (IN

CM): N/A

BASE DIAMETER (IN CM) AND SHAPE OF BASE: 6.4;

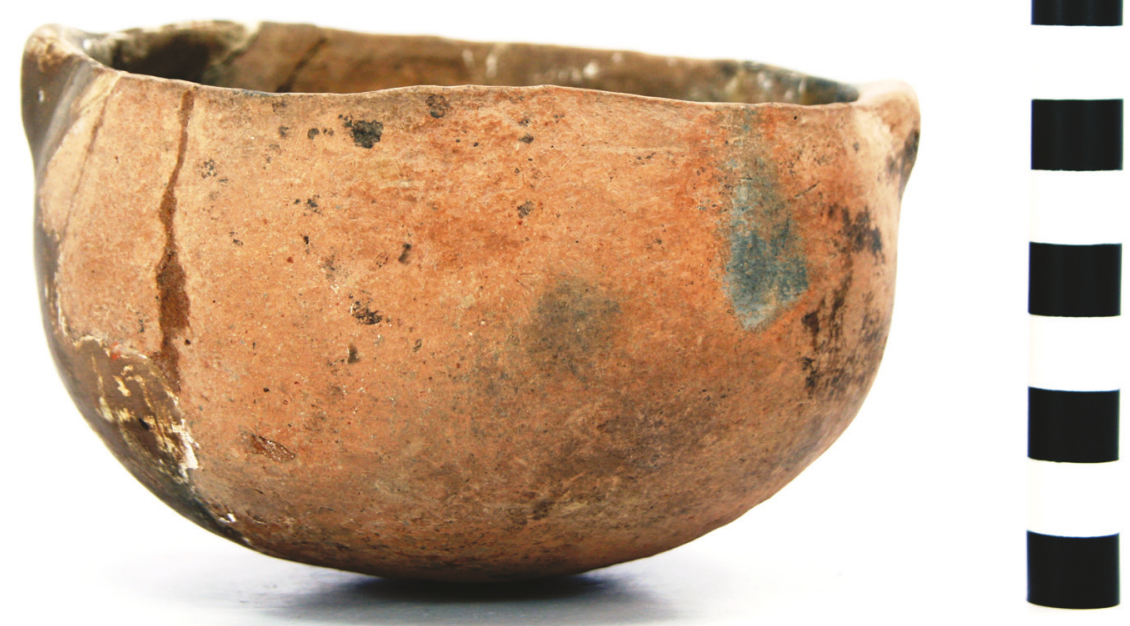

Figure 52. Bois d'Arc Plain bowl in Burial B-15 at the T. M. Sanders site (41LR2).

circular and rounded

ESTIMATED VOLUME (IN LITERS): 0.32

DECORATION (INCLUDING MOTIF AND ELEMENTS WHEN APPARENT): Plain (Figure 52)

PIGMENT USE AND LOCATION ON VESSEL: none

TYPE AND VARIETY (IF KNOWN): Bois d'Arc Plain 
SITE NAME OR SITE NUMBER: T. M. Sanders

VESSEL NO.: 399, Burial B-15

VESSEL FORM: Bowl with two lip tabs (11 x $27 \mathrm{~mm}$ in height and width) (Figure 53)

NON-PLASTICS AND PASTE: grog

RIM AND LIP FORM: Direct rim and rounded lip

CORE COLOR: A (fired and cooled in an oxidizing environment)

INTERIOR SURFACE COLOR: yellowish-brown; fire clouds on the rim

EXTERIOR SURFACE COLOR:

yellowish-brown; fire clouds on the rim

WALL THICKNESS (IN MM): rim, $5.5 \mathrm{~mm}$

INTERIOR SURFACE

TREATMENT: smoothed

EXTERIOR SURFACE

TREATMENT: smoothed

HEIGHT (IN CM): 8.2

ORIFICE DIAMETER (IN CM): 11.6

DIAMETER AT BOTTOM OF RIM

OR NECK (IN CM): N/A

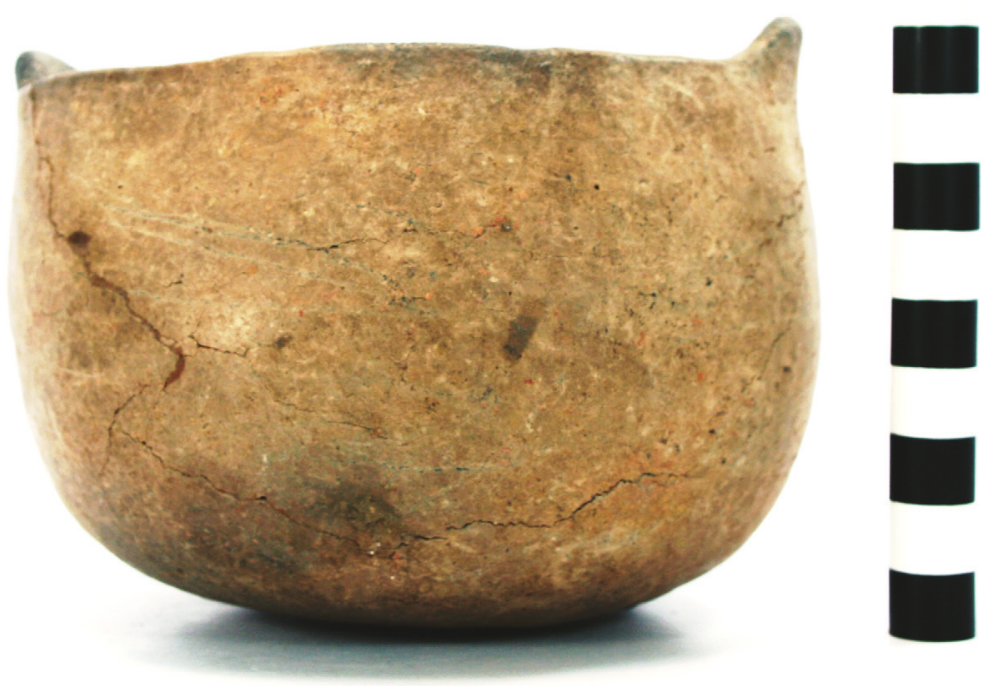

Figure 53. Bois d'Arc Plain bowl in Burial B-15 at the T. M. Sanders site (41LR2).

BASE DIAMETER (IN CM) AND SHAPE OF BASE: 8.2; circular and rounded

ESTIMATED VOLUME (IN LITERS): 0.38

DECORATION (INCLUDING MOTIF AND ELEMENTS WHEN APPARENT): Plain (Figure 53)

PIGMENT USE AND LOCATION ON VESSEL: none

TYPE AND VARIETY (IF KNOWN): Bois d'Arc Plain 
SITE NAME OR SITE NUMBER: T. M. Sanders

VESSEL NO.: 400, Burial B-15

VESSEL FORM: Bottle-Jar conjoined vessel with four loop handles (23 x $11 \mathrm{~mm}$ in height and width) (Figure 54)

NON-PLASTICS AND PASTE: grog and bone

RIM AND LIP FORM: Direct rim and rounded lip

CORE COLOR: $\mathrm{F}$ (fired in a reducing environment and cooled in the open air)

INTERIOR SURFACE COLOR: reddish-brown EXTERIOR SURFACE COLOR: reddishbrown

WALL THICKNESS (IN MM): rim, 5.5 mm

INTERIOR SURFACE TREATMENT: none

EXTERIOR SURFACE TREATMENT: smoothed

HEIGHT (IN CM): 17.1

ORIFICE DIAMETER (IN CM): 3.9

DIAMETER AT BOTTOM OF RIM OR NECK (IN CM): 4.5 (bottle); 11.3 (jar)

BASE DIAMETER (IN CM) AND SHAPE OF BASE: 7.5; circular and flat

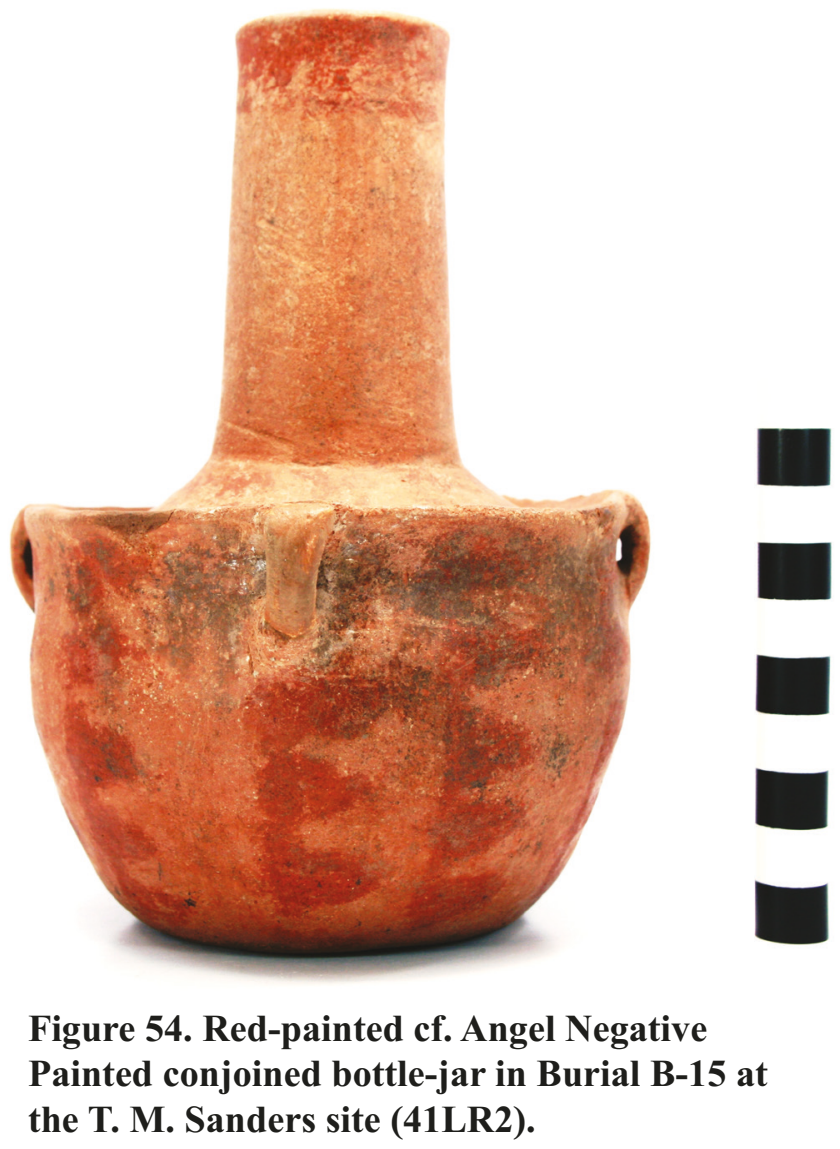

\section{ESTIMATED VOLUME (IN LITERS): 0.5}

DECORATION (INCLUDING MOTIF AND ELEMENTS WHEN APPARENT): the bottle has a single horizontal red painted band at the top of the neck. On the top of the jar section of the vessel are 10 elongated painted triangular bands, while there are also nine vertical columns of painted triangle elements (Figure 54). The decoration of this vessel resembles Angel Negative Painted varieties because of the use of red paint in bounded triangular areas (see Baumann et al. 2013:Table 1); Brown (1996:395) suggests the vessel is a Dallas Negative Painted vessel, made in the Nashville basin.

PIGMENT USE AND LOCATION ON VESSEL: none

TYPE AND VARIETY (IF KNOWN): Unidentified fine ware, cf. Angel Negative Painted 
SITE NAME OR SITE NUMBER: T. M. Sanders

VESSEL NO.: 401, Burial B-15

VESSEL FORM: Bottle

NON-PLASTICS AND PASTE: grog and bone

RIM AND LIP FORM: Direct rim and rounded lip

CORE COLOR: $\mathrm{G}$ (fired in a reducing environment and cooled in the open air)

INTERIOR SURFACE COLOR: very dark grayish-brown

EXTERIOR SURFACE COLOR: red; fire clouds on the body

WALL THICKNESS (IN MM): rim, $5.5 \mathrm{~mm}$

INTERIOR SURFACE TREATMENT: none

EXTERIOR SURFACE TREATMENT:

burnished

HEIGHT (IN CM): 15.0

ORIFICE DIAMETER (IN CM): 3.1

DIAMETER AT BOTTOM OF RIM OR

NECK (IN CM): 3.8; maximum body diameter is $9.3 \mathrm{~cm}$

BASE DIAMETER (IN CM) AND SHAPE OF BASE: 7.0; circular and flat

ESTIMATED VOLUME (IN LITERS): 0.42

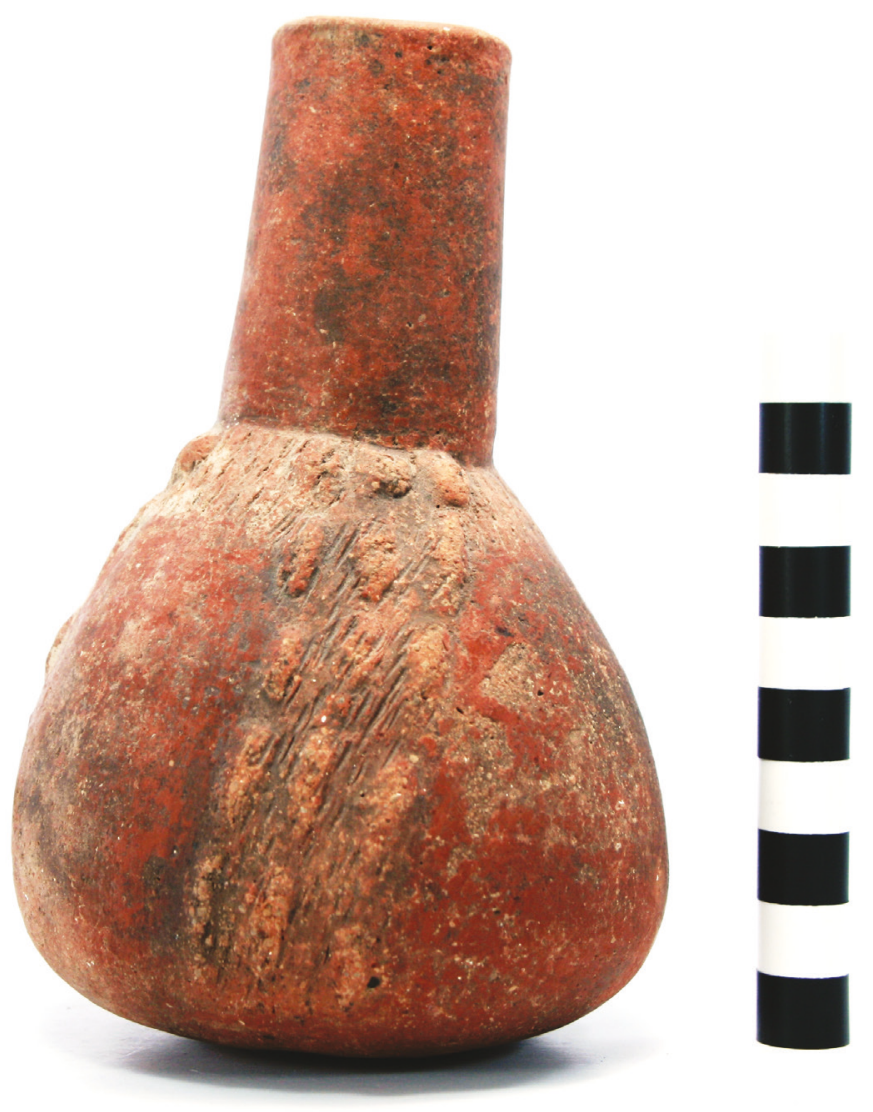

Figure 55. Maxey Noded Redware bottle in Burial B-15 at the T. M. Sanders site (41LR2).

DECORATION (INCLUDING MOTIF AND ELEMENTS WHEN APPARENT): The exterior vessel surface has a red slip, as well as appliqued and punctated elements. There are three vertical columns of five appliqued nodes interspersed with linear tool punctations. Between the appliqued-punctated columns are two horizontal rows of linear tool punctations at the top of the vessel body (Figure 55).

PIGMENT USE AND LOCATION ON VESSEL: none

TYPE AND VARIETY (IF KNOWN): Maxey Noded Redware 
SITE NAME OR SITE NUMBER: T. M. Sanders

VESSEL NO.: 402, Burial B-15

VESSEL FORM: Carinated bowl

NON-PLASTICS AND PASTE: grog

RIM AND LIP FORM: Inverted rim and rounded lip

CORE COLOR: F (fired in a reducing environment and cooled in the open air)

INTERIOR SURFACE COLOR: yellowish-brown; fire clouds on the body and base

EXTERIOR SURFACE COLOR: yellowish-brown; fire clouds on the body and base

WALL THICKNESS (IN MM): rim, $6.7 \mathrm{~mm}$

INTERIOR SURFACE

TREATMENT: smoothed

EXTERIOR SURFACE

TREATMENT: smoothed

HEIGHT (IN CM): 9.0

ORIFICE DIAMETER (IN

CM): 18.0

DIAMETER AT BOTTOM OF RIM OR NECK (IN CM): 18.8

BASE DIAMETER (IN CM) AND SHAPE OF BASE: 9.0;

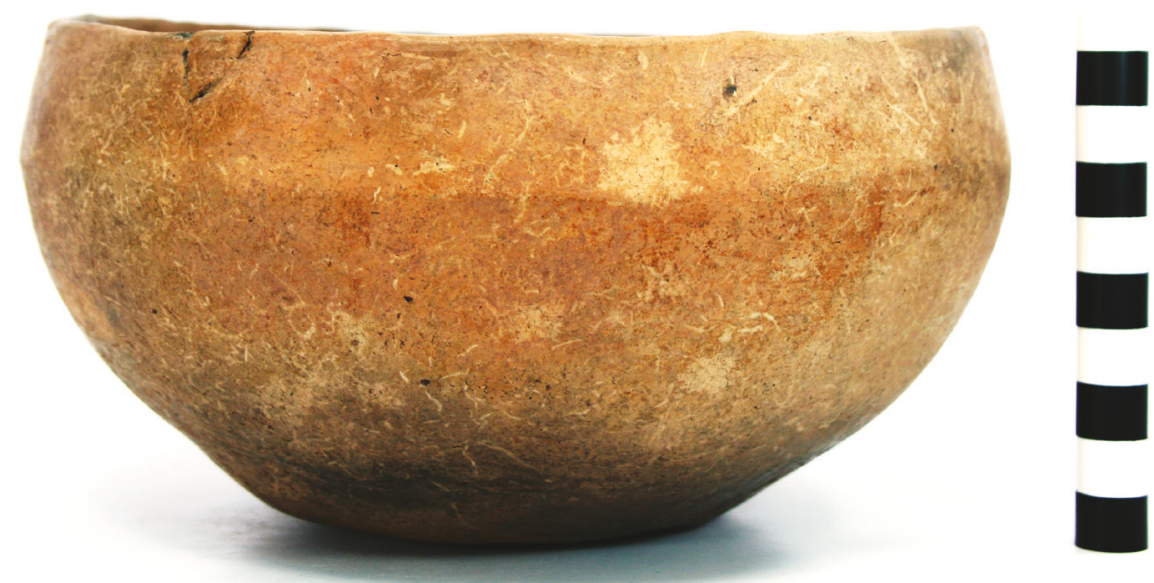

Figure 56. Bois d'Arc Plain carinated bowl in Burial B-15 at the T. M. Sanders site (41LR2). circular and flat

ESTIMATED VOLUME (IN LITERS): 1.0

DECORATION (INCLUDING MOTIF AND ELEMENTS WHEN APPARENT): Plain (Figure 56)

PIGMENT USE AND LOCATION ON VESSEL: none

TYPE AND VARIETY (IF KNOWN): Bois d'Arc Plain 
SITE NAME OR SITE NUMBER: T. M. Sanders

VESSEL NO.: 407, Burial B-16

VESSEL FORM: Bowl with two lip tabs (15 x $27 \mathrm{~mm}$ in height and width) (Figure 57)

NON-PLASTICS AND PASTE: grog

RIM AND LIP FORM: Direct rim and rounded lip

CORE COLOR: B (fired and cooled in a reducing environment)

INTERIOR SURFACE COLOR: dark grayish-brown; fire clouds on the rim and body

EXTERIOR SURFACE COLOR: black;

fire clouds on the rim, body, and base

WALL THICKNESS (IN MM): rim, 6.5 $\mathrm{mm}$

INTERIOR SURFACE TREATMENT: smoothed

EXTERIOR SURFACE TREATMENT: burnished

HEIGHT (IN CM): 8.8

ORIFICE DIAMETER (IN CM): 9.5

DIAMETER AT BOTTOM OF RIM OR

NECK (IN CM): N/A

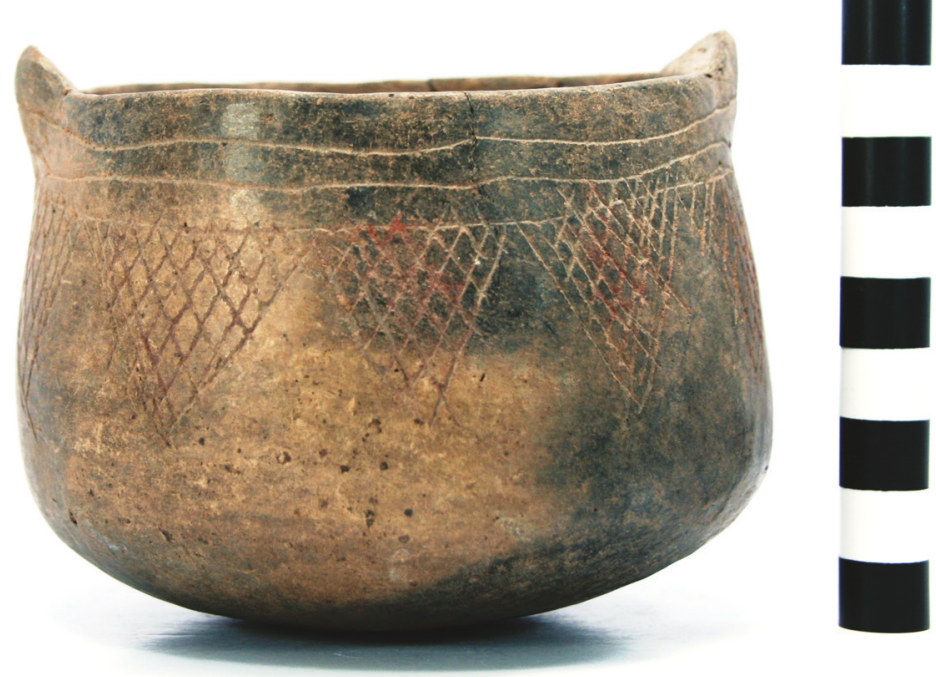

Figure 57. Sanders Engraved bowl in Burial B-16 at the T. M. Sanders site (41LR2).

BASE DIAMETER (IN CM) AND SHAPE

OF BASE: 7.9; circular and rounded

ESTIMATED VOLUME (IN LITERS): 0.34

DECORATION (INCLUDING MOTIF AND ELEMENTS WHEN APPARENT): the top part of the bowl has three equally-spaced horizontal engraved lines. Pendant from the bottom horizontal line are 10 large engraved triangle elements filled with cross-hatched engraved lines (Figure 57).

PIGMENT USE AND LOCATION ON VESSEL: red pigment in the engraved lines

TYPE AND VARIETY (IF KNOWN): Sanders Engraved 
SITE NAME OR SITE NUMBER: T. M. Sanders

VESSEL NO.: 408, Burial B-16

VESSEL FORM: Bowl

NON-PLASTICS AND PASTE: grog

RIM AND LIP FORM: Direct rim and rounded lip

CORE COLOR: $\mathrm{G}$ (fired in a reducing environment and cooled in the open air)

INTERIOR SURFACE COLOR: very dark grayish-brown

EXTERIOR SURFACE COLOR: red; fire clouds on the base

WALL THICKNESS (IN MM): rim, $4.3 \mathrm{~mm}$

INTERIOR SURFACE TREATMENT: none

EXTERIOR SURFACE

TREATMENT: smoothed

HEIGHT (IN CM): 6.4

ORIFICE DIAMETER (IN CM):

17.1

DIAMETER AT BOTTOM OF

RIM OR NECK (IN CM): N/A

BASE DIAMETER (IN CM) AND SHAPE OF BASE: 10.2; circular and flat

ESTIMATED VOLUME (IN

LITERS): 0.44

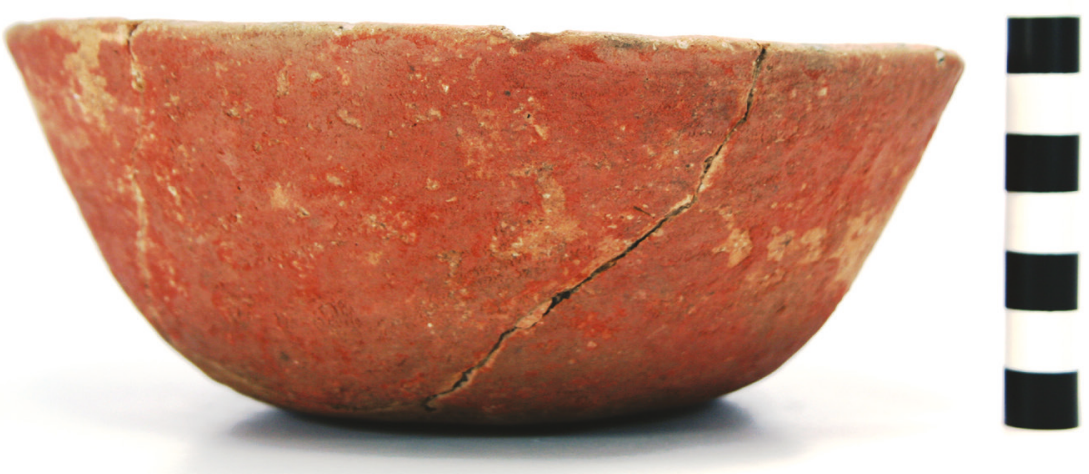

Figure 58. Sanders Slipped bowl in Burial B-16 at the T. M. Sanders site (41LR2).

DECORATION (INCLUDING MOTIF AND ELEMENTS WHEN APPARENT): The vessel has an exterior red slip (Figure 58).

PIGMENT USE AND LOCATION ON VESSEL: none

TYPE AND VARIETY (IF KNOWN): Sanders Slipped 
SITE NAME OR SITE NUMBER: T. M. Sanders

VESSEL NO.: 427, Burial B-17

VESSEL FORM: Bottle

NON-PLASTICS AND PASTE: grog

RIM AND LIP FORM: Direct rim and rounded lip

CORE COLOR: $G$ (fired in a reducing environment and cooled in the open air)

INTERIOR SURFACE COLOR: dark grayish-brown

EXTERIOR SURFACE COLOR: red; fire clouds on the base

WALL THICKNESS (IN MM): rim, 6.6 mm

INTERIOR SURFACE TREATMENT: none

EXTERIOR SURFACE TREATMENT: burnished

HEIGHT (IN CM): 20.5

ORIFICE DIAMETER (IN CM): 3.7

DIAMETER AT BOTTOM OF RIM OR NECK (IN $\mathrm{CM}$ ): 4.9 ; maximum body diameter is $13.9 \mathrm{~cm}$

BASE DIAMETER (IN CM) AND SHAPE OF BASE: 11.5; circular and flat

ESTIMATED VOLUME (IN LITERS): 0.9

DECORATION (INCLUDING MOTIF AND ELEMENTS WHEN APPARENT): The exterior surface of the vessel has a red slip (Figure 59).

PIGMENT USE AND LOCATION ON VESSEL: none TYPE AND VARIETY (IF KNOWN): Sanders Slipped

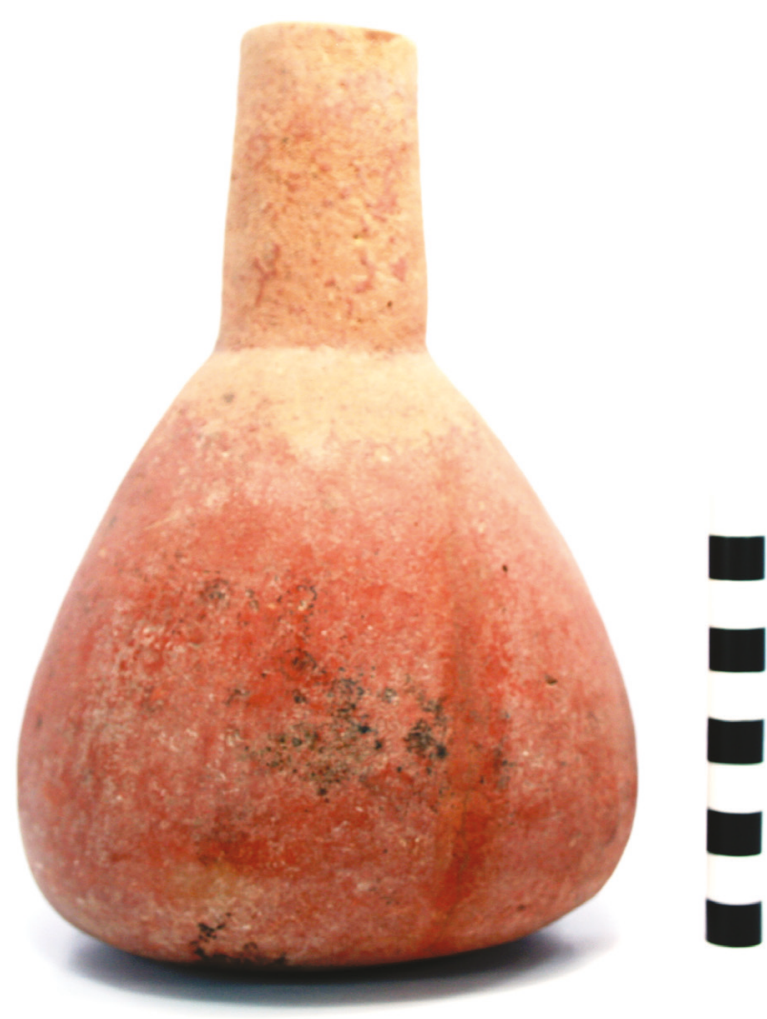

Figure 59. Sanders Slipped bottle in Burial B-17 at the T. N. Sanders site (41LR2). 
SITE NAME OR SITE NUMBER: T. M. Sanders

VESSEL NO.: 430, Burial B-17

VESSEL FORM: Barrel-shaped jar with two opposed suspension holes (5.0 $\mathrm{mm}$ in diameter) (Figure 60) on the rim

NON-PLASTICS AND PASTE: grog

RIM AND LIP FORM: Direct rim and rounded lip

CORE COLOR: F (fired in a reducing environment and cooled in the open air)

INTERIOR SURFACE COLOR: brown

EXTERIOR SURFACE COLOR: brown; fire clouds on the body and base; organic residue on the rim and body

WALL THICKNESS (IN MM): rim, 6.1 $\mathrm{mm}$

INTERIOR SURFACE TREATMENT: smoothed

EXTERIOR SURFACE TREATMENT: burnished

HEIGHT (IN CM): 15.2; body height is $11.0 \mathrm{~cm}$

ORIFICE DIAMETER (IN CM): 10.4

DIAMETER AT BOTTOM OF RIM OR NECK (IN CM): 10.4

BASE DIAMETER (IN CM) AND SHAPE OF BASE: 7.8; circular and rounded

ESTIMATED VOLUME (IN LITERS): 0.95

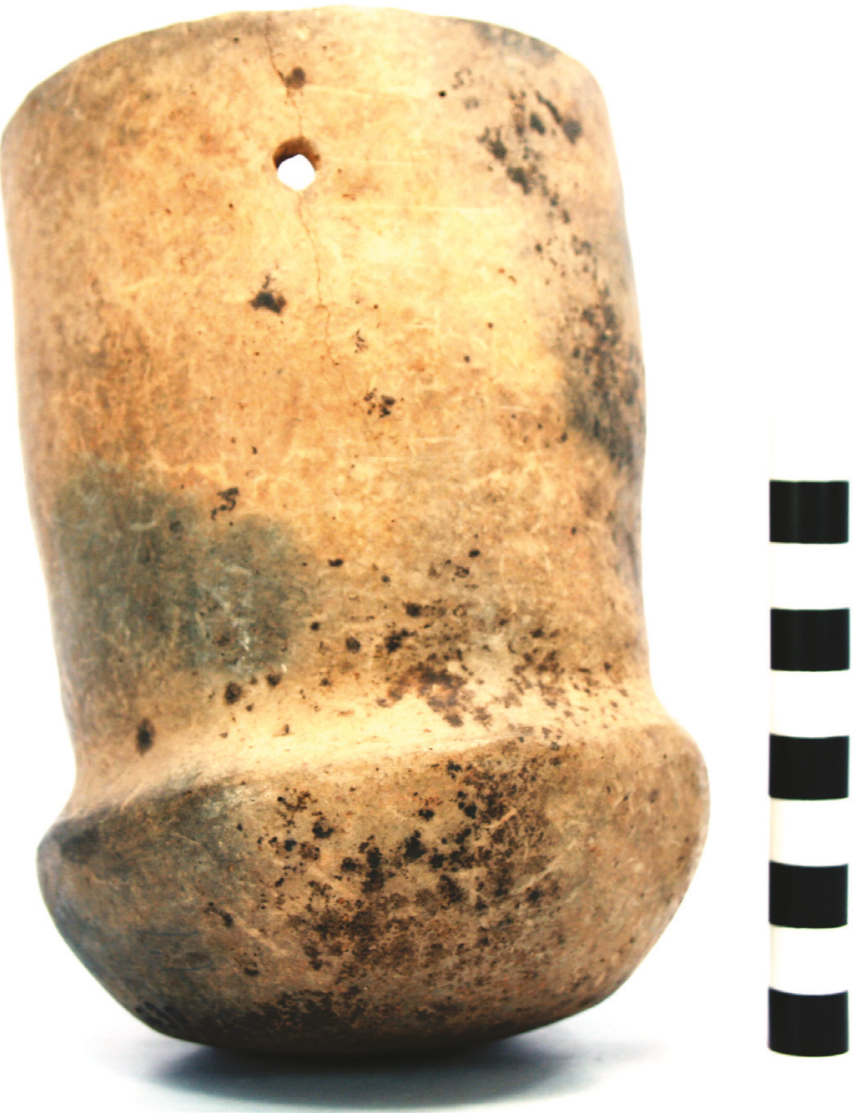

Figure 60. Bois d'Arc Plain jar in Burial B-17 at the T. M. Sanders site (41LR2).

DECORATION (INCLUDING MOTIF AND

ELEMENTS WHEN APPARENT): Plain (Figure 60)

PIGMENT USE AND LOCATION ON VESSEL: none

TYPE AND VARIETY (IF KNOWN): Bois d'Arc Plain 
SITE NAME OR SITE NUMBER: T. M. Sanders

VESSEL NO.: 431, Burial B-17

VESSEL FORM: Bowl with two lip tabs (10 x $28 \mathrm{~mm}$ in height and width) (Figure 61)

NON-PLASTICS AND PASTE: bone

RIM AND LIP FORM: Inverted rim and rounded lip

CORE COLOR: F (fired in a reducing environment and cooled in the open air)

INTERIOR SURFACE COLOR: dark yellowish-brown; fire clouds on the rim and body

EXTERIOR SURFACE COLOR: brown; fire clouds on the rim and body

WALL THICKNESS (IN MM): rim, $4.5 \mathrm{~mm}$

INTERIOR SURFACE TREATMENT:

smoothed

EXTERIOR SURFACE TREATMENT:

burnished

HEIGHT (IN CM): 10.2

ORIFICE DIAMETER (IN CM): 8.9

DIAMETER AT BOTTOM OF RIM OR

NECK (IN CM): N/A

BASE DIAMETER (IN CM) AND SHAPE OF

BASE: 7.0; circular and rounded

ESTIMATED VOLUME (IN LITERS): 0.36

DECORATION (INCLUDING MOTIF AND

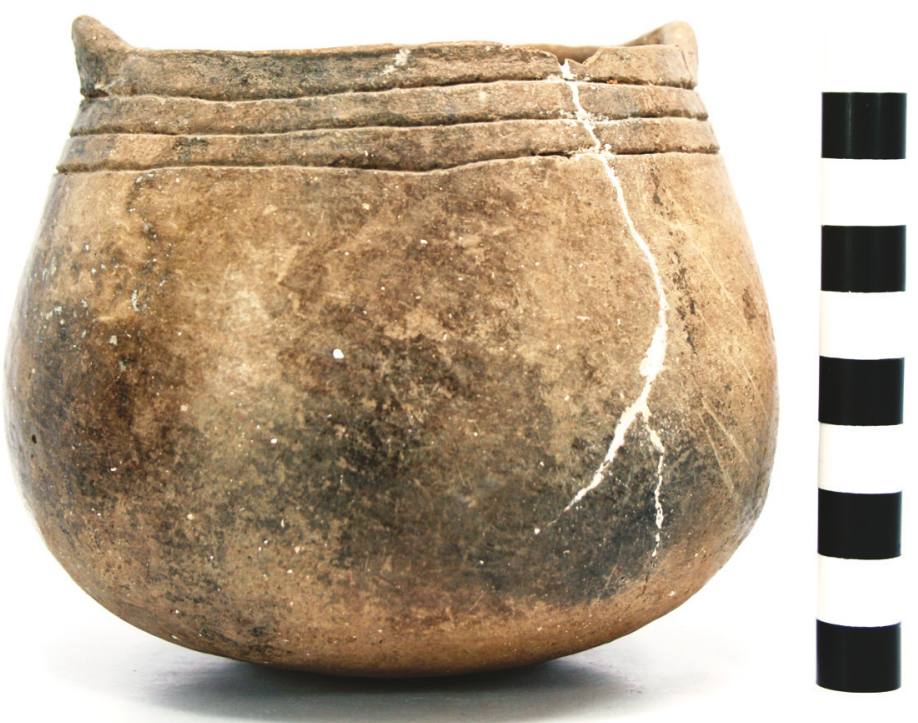

Figure 61. Hickory Engraved bowl in Burial B-17 at the T. M. Sanders site (41LR2).

ELEMENTS WHEN APPARENT): The upper

part of the vessel is decorated with three horizontal engraved lines (Figure 61).

PIGMENT USE AND LOCATION ON VESSEL: none

TYPE AND VARIETY (IF KNOWN): Hickory Engraved 
SITE NAME OR SITE NUMBER: T. M. Sanders

VESSEL NO.: 432, Burial B-17

VESSEL FORM: Jar with two opposed strap handles (19 x $34 \mathrm{~mm}$ in width and height) with two lip tabs per handle (Figure 62)

NON-PLASTICS AND PASTE: grog

RIM AND LIP FORM: Everted rim and rounded lip

CORE COLOR: G (fired in a reducing environment and cooled in the open air)

INTERIOR SURFACE COLOR: very dark grayish-brown; fire clouds on the rim and body

\section{EXTERIOR SURFACE COLOR:}

reddish-brown; fire clouds on the rim, body, and the base

WALL THICKNESS (IN MM): rim, 3.9 $\mathrm{mm}$

INTERIOR SURFACE TREATMENT: burnished on the rim

EXTERIOR SURFACE TREATMENT: none

HEIGHT (IN CM): 9.5

ORIFICE DIAMETER (IN CM): 10.0

DIAMETER AT BOTTOM OF RIM OR NECK (IN CM): 9.0

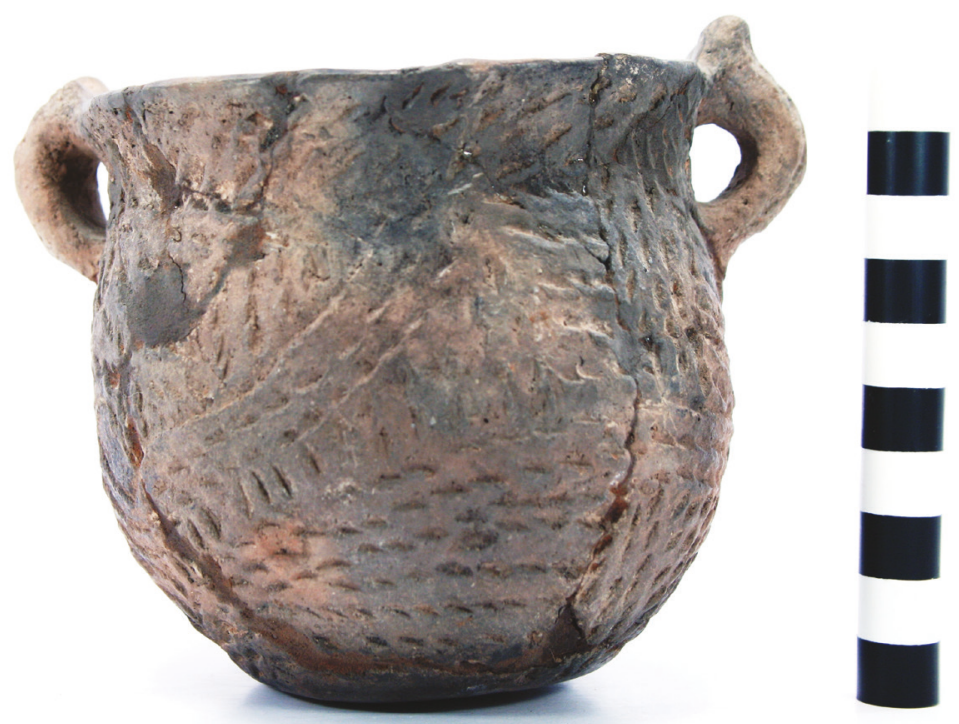

Figure 62. Monkstown Fingernail Impressed jar in Burial B-17 at the T. M. Sanders site (41LR2).

BASE DIAMETER (IN CM) AND SHAPE OF BASE: 6.0; circular and flat

ESTIMATED VOLUME (IN LITERS): 0.57

DECORATION (INCLUDING MOTIF AND ELEMENTS WHEN APPARENT): The rim is divided into two panels by three vertical rows of fingernail punctations. The panels on the body have three or seven horizontal rows of fingernail punctations as well as diagonal and diagonal opposed rows of fingernail punctations. The bottom of each panel has three horizontal rows of fingernail punctations. The two handles have three vertical rows of punctations (Figure 62).

PIGMENT USE AND LOCATION ON VESSEL: none

TYPE AND VARIETY (IF KNOWN): Monkstown Fingernail Impressed 
SITE NAME OR SITE NUMBER: T. M. Sanders

VESSEL NO.: 433, Burial B-17

VESSEL FORM: Jar with two loop handles (21 x $10 \mathrm{~mm}$ in height and width) (Figure 63a); each of the handles has a drilled hole on their top surface (Figure 63b)

NON-PLASTICS AND PASTE: shell

RIM AND LIP FORM: Everted rim and rounded lip

CORE COLOR: B (fired and cooled in a reducing environment)

INTERIOR SURFACE COLOR:

very dark gray

EXTERIOR SURFACE COLOR:

very dark gray

WALL THICKNESS (IN MM): rim, 4.8 mm

INTERIOR SURFACE TREATMENT: none

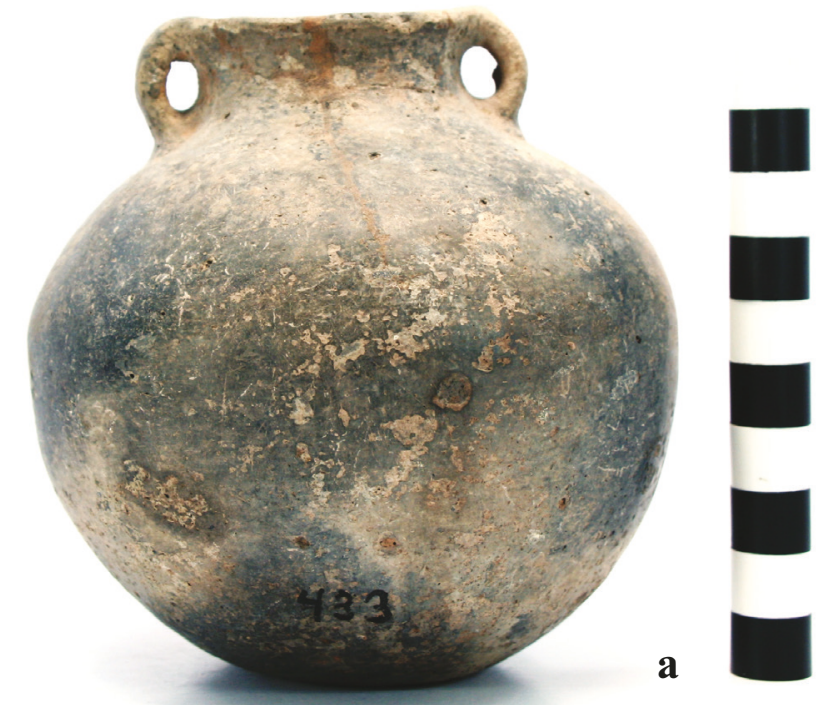

EXTERIOR SURFACE TREATMENT:

smoothed

HEIGHT (IN CM): 10.8

ORIFICE DIAMETER (IN CM): 4.0

DIAMETER AT BOTTOM OF RIM OR NECK (IN CM): 4.5

BASE DIAMETER (IN CM) AND SHAPE OF BASE: 3.7 ; circular and rounded

ESTIMATED VOLUME (IN LITERS): 0.17

DECORATION (INCLUDING MOTIF AND

ELEMENTS WHEN APPARENT): Plain

(Figure 63a)

PIGMENT USE AND LOCATION ON

Figure 63. Plain shell-tempered jar in Burial B-17 at the T. M. Sanders site (41LR2): a, side view; $b$, view of drilled holes in handles.

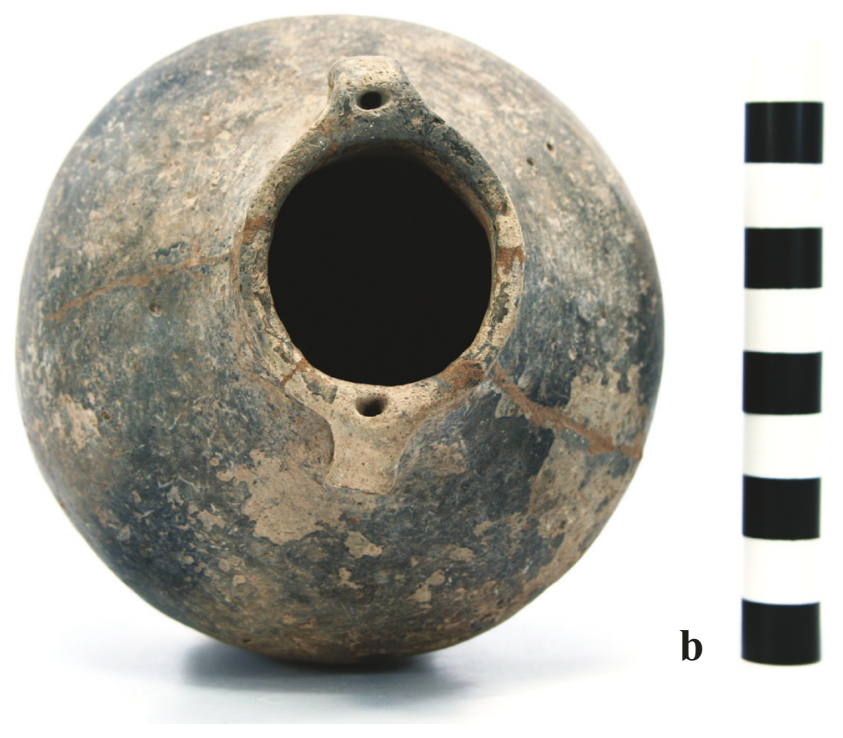

VESSEL: none

TYPE AND VARIETY (IF KNOWN): Unidentified plain ware, probably related to Nocona Plain found on Plains Village sites upstream from the Sanders site along the Red River (Bell and Baerreis 1951; Suhm and Jelks 1962:115; Rohn 1998:129), as this ware does have vessels with handles. 
SITE NAME OR SITE NUMBER: T. M. Sanders

VESSEL NO.: 434, Burial B-17

VESSEL FORM: Barrel-shaped jar with two opposed suspension holes (1.7 $\mathrm{mm}$ in diameter) (Figure 64)

NON-PLASTICS AND PASTE: grog

RIM AND LIP FORM: Direct rim and rounded lip

CORE COLOR: F (fired in a reducing environment and cooled in the open air)

INTERIOR SURFACE COLOR: brown

EXTERIOR SURFACE COLOR: brown; fire clouds on the body and base

WALL THICKNESS (IN MM): rim, $6.7 \mathrm{~mm}$

INTERIOR SURFACE TREATMENT:

smoothed

EXTERIOR SURFACE TREATMENT:

burnished

HEIGHT (IN CM): 8.8

ORIFICE DIAMETER (IN CM): 6.0

DIAMETER AT BOTTOM OF RIM OR NECK (IN CM): N/A

BASE DIAMETER (IN CM) AND SHAPE OF BASE: 5.8; circular and flat

ESTIMATED VOLUME (IN LITERS): 0.3

DECORATION (INCLUDING MOTIF AND ELEMENTS WHEN APPARENT): The rim is decorated with four large engraved triangle elements pendant from the vessel lip. Each engraved triangle is filled with six diagonal hatched engraved lines (Figure 64).

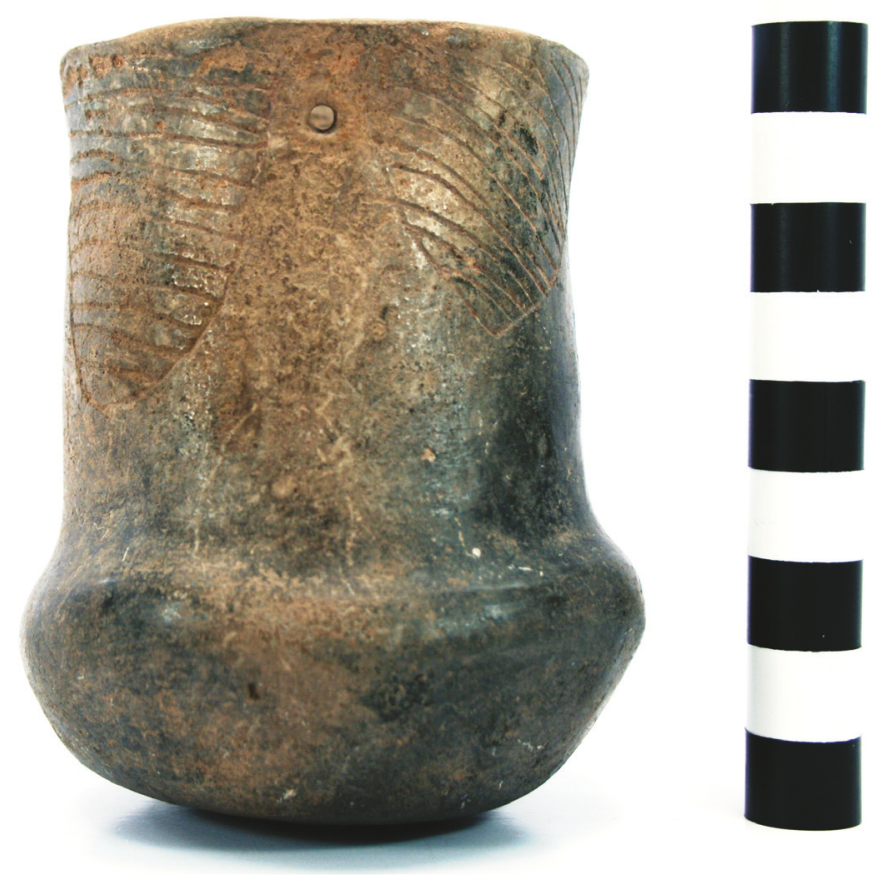

Figure 64. Sanders Engraved jar in Burial B-17 at the T. M. Sanders site (41LR2).

PIGMENT USE AND LOCATION ON VESSEL: none

TYPE AND VARIETY (IF KNOWN): Sanders Engraved 
SITE NAME OR SITE NUMBER: T. M. Sanders

VESSEL NO.: 453

VESSEL FORM: Jar with two opposed lug handles (28.4 x $18.5 \mathrm{~mm}$ in height and width) with two lip tabs on each handle (Figure 65)

NON-PLASTICS AND PASTE: grog

RIM AND LIP FORM: Everted rim and rounded lip

CORE COLOR: $\mathrm{F}$ (fired in a reducing environment and cooled in the open air)

INTERIOR SURFACE COLOR: reddish-brown; fire clouds on the body

EXTERIOR SURFACE COLOR: reddish-brown; fire clouds on the rim and body

WALL THICKNESS (IN MM): rim, $6.8 \mathrm{~mm}$

INTERIOR SURFACE TREATMENT: smoothed

EXTERIOR SURFACE TREATMENT: smoothed on the body

HEIGHT (IN CM): 23.2

ORIFICE DIAMETER (IN CM): 21.0

DIAMETER AT BOTTOM OF RIM OR NECK (IN CM): 18.5

BASE DIAMETER (IN CM) AND SHAPE OF BASE: 9.0; circular and flat

ESTIMATED VOLUME (IN LITERS): 4.4

DECORATION (INCLUDING MOTIF AND ELEMENTS WHEN APPARENT): The vessel has faint horizontal brushed or closely-spaced incised lines on portions of the rim. The vessel body is divided into four sections by two or three vertical columns of fingernail punctations. Each section is

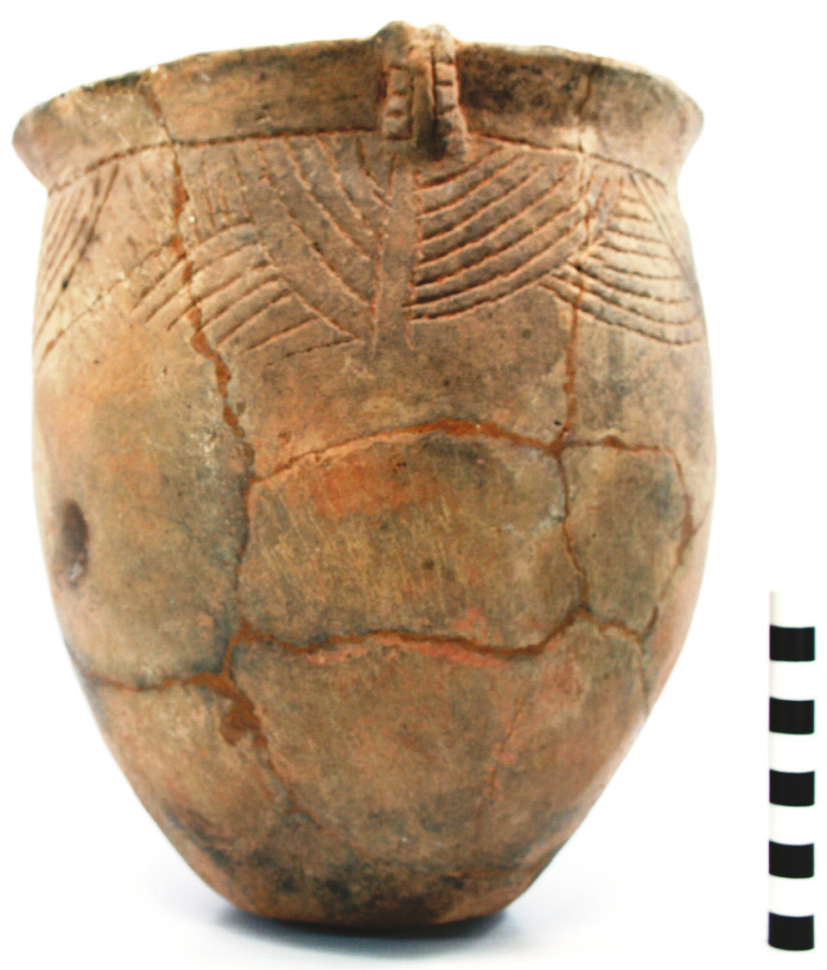

Figure 65. Monkstown Fingernail Impressed jar from the T. M. Sanders site. decorated with three or four opposed curvilinear fingernail punctated zones (Figure 65).

PIGMENT USE AND LOCATION ON VESSEL: none

TYPE AND VARIETY (IF KNOWN): Monkstown Fingernail Impressed 
SITE NAME OR SITE NUMBER: T. M. Sanders

VESSEL NO.: 469

VESSEL FORM: Bottle

NON-PLASTICS AND PASTE: bone

RIM AND LIP FORM: Direct rim and rounded lip

CORE COLOR: $\mathrm{G}$ (fired in a reducing environment and cooled in the open air)

INTERIOR SURFACE COLOR: dark grayish-brown

EXTERIOR SURFACE COLOR: dark brown

WALL THICKNESS (IN MM): rim, 5.6 mm

INTERIOR SURFACE TREATMENT: none

EXTERIOR SURFACE TREATMENT: burnished

HEIGHT (IN CM): 20.2

ORIFICE DIAMETER (IN CM): 4.2

DIAMETER AT BOTTOM OF RIM OR NECK (IN CM):

4.8 ; maximum body diameter is $12.6 \mathrm{~cm}$

BASE DIAMETER (IN CM) AND SHAPE OF BASE:

8.0; circular and flat

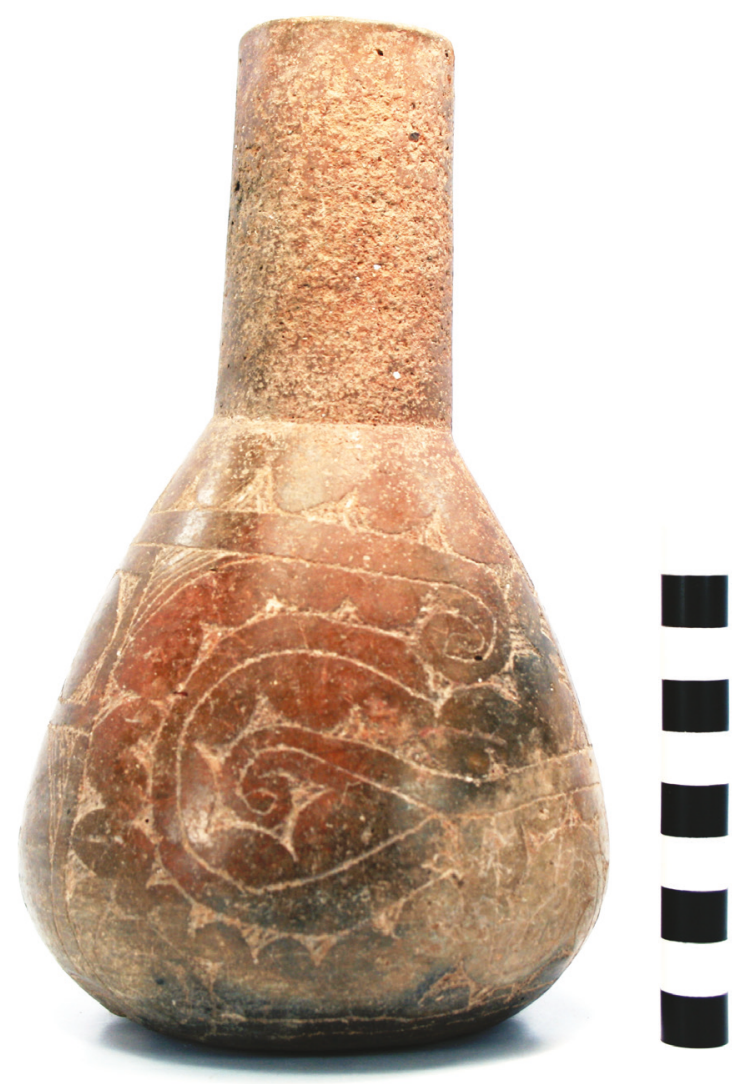

Figure 66. Haley Engraved bottle from the T. M. Sanders site (41LR2).

ESTIMATED VOLUME (IN LITERS): 0.64

DECORATION (INCLUDING MOTIF AND ELEMENTS WHEN APPARENT): The vessel body is decorated with a series of engraved elements in rectangular panels with triangular hatched corners. The engraved elements include rows of hatched or excised triangles pendant from the vertical portions of panels, four curvilinear hooked arms with excised triangular tick marks, and two small rectangles with excised corners. The primary element is a series of six large concentric and curvilinear engraved lines that end in a hooked arm. Alternating curvilinear engraved lines have large excised pendant triangles (Figure 66).

PIGMENT USE AND LOCATION ON VESSEL: none

TYPE AND VARIETY (IF KNOWN): Haley Engraved 
SITE NAME OR SITE NUMBER: T. M. Sanders

VESSEL NO.: 515, Burial B-20

VESSEL FORM: Bowl

NON-PLASTICS AND PASTE: grog

RIM AND LIP FORM: Direct rim and rounded lip

CORE COLOR: $\mathrm{F}$ (fired in a reducing environment and cooled in the open air)

INTERIOR SURFACE COLOR: red

EXTERIOR SURFACE COLOR: red; fire clouds on the base

WALL THICKNESS (IN MM): rim, $6.5 \mathrm{~mm}$

INTERIOR SURFACE TREATMENT: smoothed

EXTERIOR SURFACE TREATMENT: burnished

HEIGHT (IN CM): 12.1

ORIFICE DIAMETER (IN CM): 36.3

DIAMETER AT BOTTOM OF RIM OR NECK (IN CM): N/A

BASE DIAMETER (IN CM) AND SHAPE OF BASE: 11.5; circular and rounded

ESTIMATED VOLUME (IN LITERS): 2.6

DECORATION (INCLUDING MOTIF AND ELEMENTS WHEN APPARENT): The vessel has a red slip on both interior and exterior surfaces (Figure 67).

PIGMENT USE AND LOCATION ON VESSEL: none

TYPE AND VARIETY (IF KNOWN): Sanders Slipped

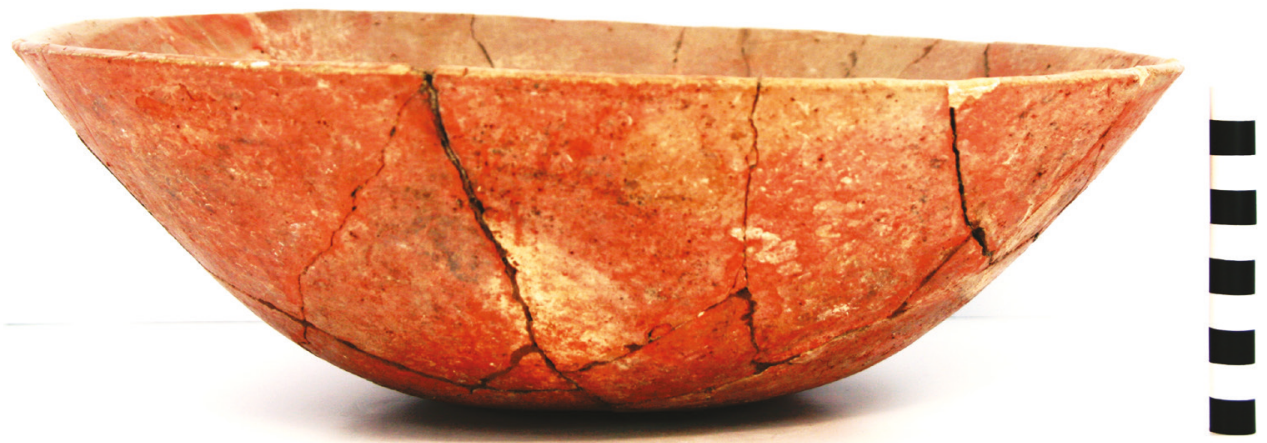

Figure 67. Sanders Slipped bowl in Burial B-20 at the T. M. Sanders site (41LR2). 
SITE NAME OR SITE NUMBER: T. M. Sanders

VESSEL NO.: 516, Burial B-20

VESSEL FORM: Carinated bowl

NON-PLASTICS AND PASTE: grog

RIM AND LIP FORM: Direct rim and flat lip

CORE COLOR: $\mathrm{G}$ (fired in a reducing environment and cooled in the open air)

INTERIOR SURFACE COLOR: dark grayish-brown

EXTERIOR SURFACE COLOR: dark reddish-brown

WALL THICKNESS (IN MM): rim, $6.6 \mathrm{~mm}$

INTERIOR SURFACE TREATMENT: smoothed

EXTERIOR SURFACE TREATMENT: burnished

HEIGHT (IN CM): 10.3

ORIFICE DIAMETER (IN CM): 34.5

DIAMETER AT BOTTOM OF RIM OR NECK (IN CM): 34.3

BASE DIAMETER (IN CM) AND SHAPE OF BASE: 12.7; circular and flat

ESTIMATED VOLUME (IN LITERS): 2.1

DECORATION (INCLUDING MOTIF AND ELEMENTS WHEN APPARENT): The rim is decorated with a series of 31 upper and lower pendant triangles whose apexes touch. Each of the triangle elements is filled with cross-hatched engraved lines (Figure 68).

PIGMENT USE AND LOCATION ON VESSEL: none

TYPE AND VARIETY (IF KNOWN): Sanders Engraved

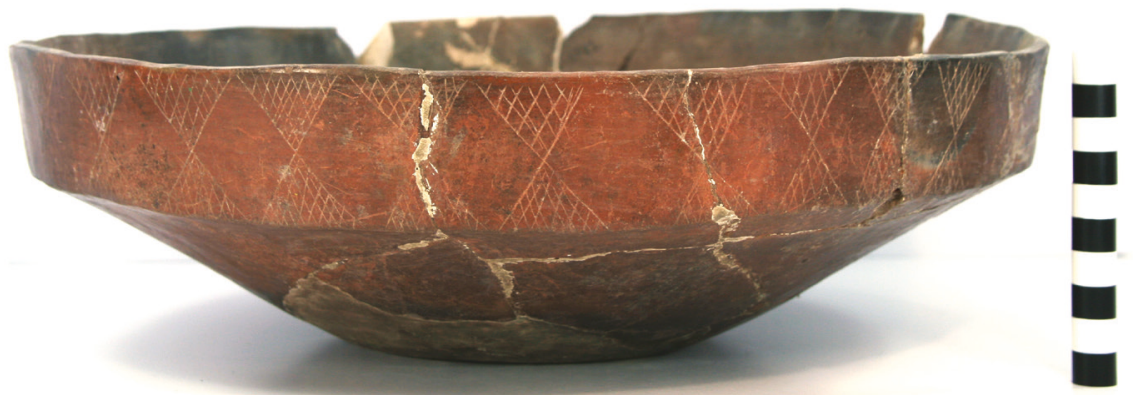

Figure 68. Sanders Engraved carinated bowl in Burial B-20 at the T. M. Sanders site (41LR2). 
SITE NAME OR SITE NUMBER: T. M. Sanders

VESSEL NO.: 517, Burial B-20

VESSEL FORM: Neckless bottle with two opposed suspension holes (8.0 $\mathrm{mm}$ in diameter) (Figure 69)

NON-PLASTICS AND PASTE: grog

RIM AND LIP FORM: Inverted rim and rounded lip

CORE COLOR: $\mathrm{G}$ (fired in a reducing environment and cooled in the open air)

INTERIOR SURFACE COLOR: dark grayish-brown

EXTERIOR SURFACE COLOR: brown; fire clouds on the body

WALL THICKNESS (IN MM): rim, $7.0 \mathrm{~mm}$

INTERIOR SURFACE TREATMENT: none

EXTERIOR SURFACE TREATMENT: burnished

HEIGHT (IN CM): 32.0

ORIFICE DIAMETER (IN CM): 4.4

DIAMETER AT BOTTOM OF RIM OR NECK (IN CM):

$\mathrm{N} / \mathrm{A}$; maximum body diameter is $20.0 \mathrm{~cm}$

BASE DIAMETER (IN CM) AND SHAPE OF BASE:

12.7; circular and flat

ESTIMATED VOLUME (IN LITERS): 1.6

DECORATION (INCLUDING MOTIF AND ELEMENTS WHEN APPARENT): The upper part of the vessel has a single horizontal engraved line with three large engraved pendant triangles. Each pendant triangle is filled with crosshatched engraved lines (Figure 69).

PIGMENT USE AND LOCATION ON VESSEL: none TYPE AND VARIETY (IF KNOWN): Sanders Engraved

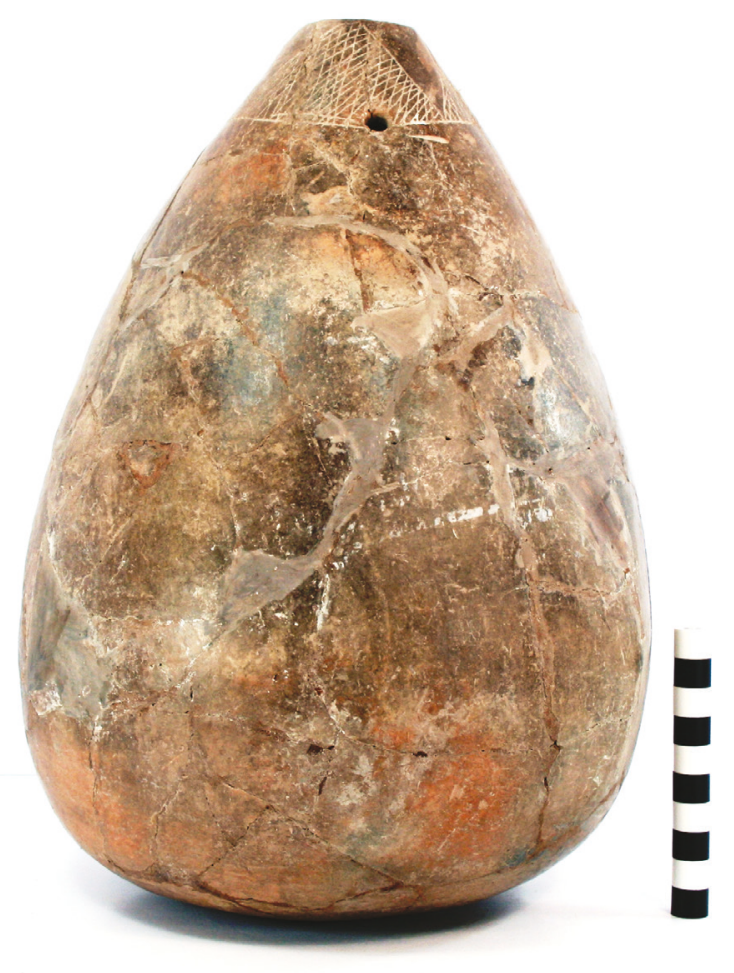

Figure 69. Sanders Engraved neckless bottle in Burial B-20 at the T. $M$. Sanders site (41LR2). 
SITE NAME OR SITE NUMBER: T. M. Sanders

VESSEL NO.: 519, Burial B-20

VESSEL FORM: Carinated bowl

NON-PLASTICS AND PASTE: grog and bone

RIM AND LIP FORM: Inverted rim and rounded lip

CORE COLOR: F (fired in a reducing environment and cooled in the open air)

INTERIOR SURFACE COLOR: reddish-brown

EXTERIOR SURFACE COLOR: reddish-brown; fire clouds on the body and base

WALL THICKNESS (IN MM): rim, $8.2 \mathrm{~mm}$

INTERIOR SURFACE TREATMENT: smoothed

EXTERIOR SURFACE TREATMENT: smoothed

HEIGHT (IN CM): 14.0

ORIFICE DIAMETER (IN CM): 39.0

DIAMETER AT BOTTOM OF RIM OR NECK (IN CM): 40.0

BASE DIAMETER (IN CM) AND SHAPE OF BASE: 13.0; circular and flat

ESTIMATED VOLUME (IN LITERS): 4.9

DECORATION (INCLUDING MOTIF AND ELEMENTS WHEN APPARENT): Plain (Figure 70)

PIGMENT USE AND LOCATION ON VESSEL: none

TYPE AND VARIETY (IF KNOWN): Bois d'Arc Plain

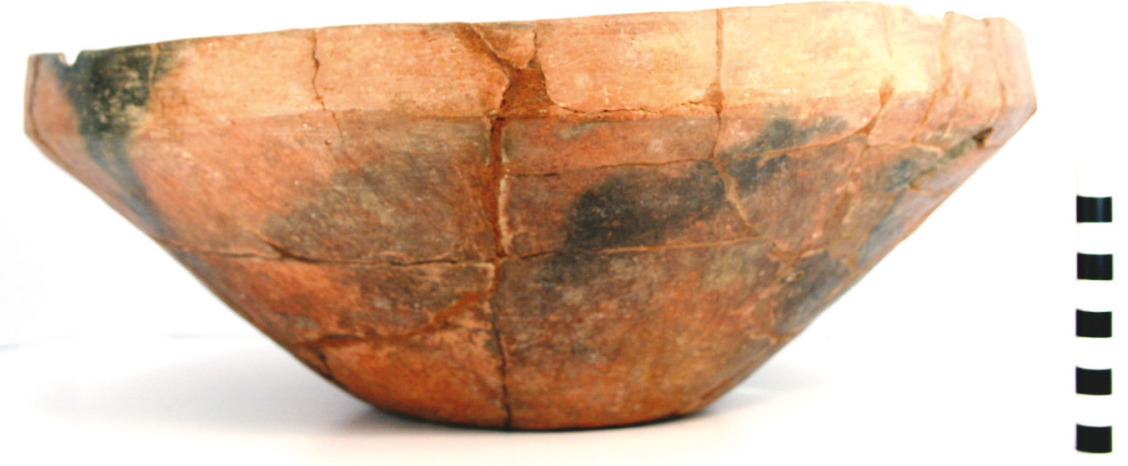

Figure 70. Bois d'Arc Plain carinated bowl in Burial B-20 at the T. M. Sanders site (41LR2). 
SITE NAME OR SITE NUMBER: T. M. Sanders

VESSEL NO.: 520, Burial B-20

VESSEL FORM: Carinated bowl

NON-PLASTICS AND PASTE: grog and bone

RIM AND LIP FORM: Direct rim and rounded lip

CORE COLOR: F (fired in a reducing environment and cooled in the open air)

INTERIOR SURFACE COLOR: dark yellowish-brown; fire clouds on the body and base

EXTERIOR SURFACE COLOR: dark yellowish-brown; fire clouds on the rim, body, and base

WALL THICKNESS (IN MM): rim, $7.4 \mathrm{~mm}$

INTERIOR SURFACE TREATMENT: smoothed

EXTERIOR SURFACE TREATMENT: smoothed

HEIGHT (IN CM): 17.8

ORIFICE DIAMETER (IN CM): 36.1

DIAMETER AT BOTTOM OF RIM

OR NECK (IN CM): 36.0

BASE DIAMETER (IN CM)

AND SHAPE OF BASE: 14.0;

circular and flat

ESTIMATED VOLUME

(IN LITERS): 5.8

DECORATION (INCLUDING

MOTIF AND ELEMENTS WHEN

APPARENT): Plain (Figure 71)

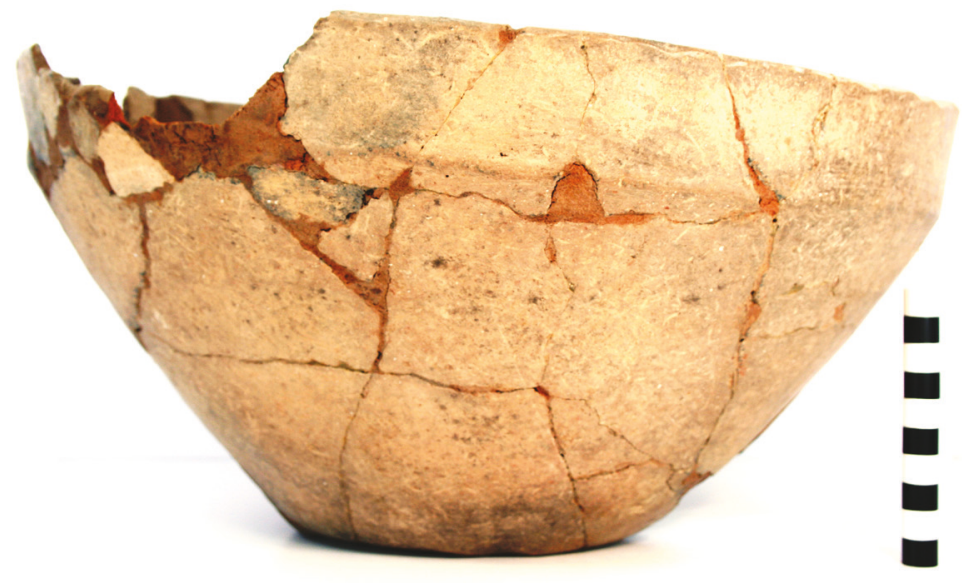

Figure 71. Bois d'Arc Plain carinated bowl in Burial B-20 at the T. M. Sanders site (41LR2).

PIGMENT USE AND LOCATION ON VESSEL: none

TYPE AND VARIETY (IF KNOWN): Bois d'Arc Plain 
SITE NAME OR SITE NUMBER: T. M. Sanders

VESSEL NO.: 521, Burial B-20

VESSEL FORM: Carinated bowl

NON-PLASTICS AND PASTE: bone

RIM AND LIP FORM: Direct rim and rounded lip

CORE COLOR: $\mathrm{G}$ (fired in a reducing environment and cooled in the open air)

INTERIOR SURFACE COLOR: very dark grayish-brown; fire clouds on the rim, body, and base

EXTERIOR SURFACE COLOR: reddish-brown; fire clouds on the rim, body, and base

WALL THICKNESS (IN MM): rim, $7.0 \mathrm{~mm}$

INTERIOR SURFACE TREATMENT: smoothed

EXTERIOR SURFACE TREATMENT: burnished

HEIGHT (IN CM): 11.8

ORIFICE DIAMETER (IN CM): 30.5

DIAMETER AT BOTTOM OF RIM OR NECK (IN CM): 29.5

BASE DIAMETER (IN CM) AND SHAPE OF BASE: 12.0; circular and flat

ESTIMATED VOLUME (IN LITERS): 2.2

DECORATION (INCLUDING MOTIF AND ELEMENTS WHEN APPARENT): Plain (Figure 72)

PIGMENT USE AND LOCATION ON VESSEL: none

TYPE AND VARIETY (IF KNOWN): Bois d'Arc Plain

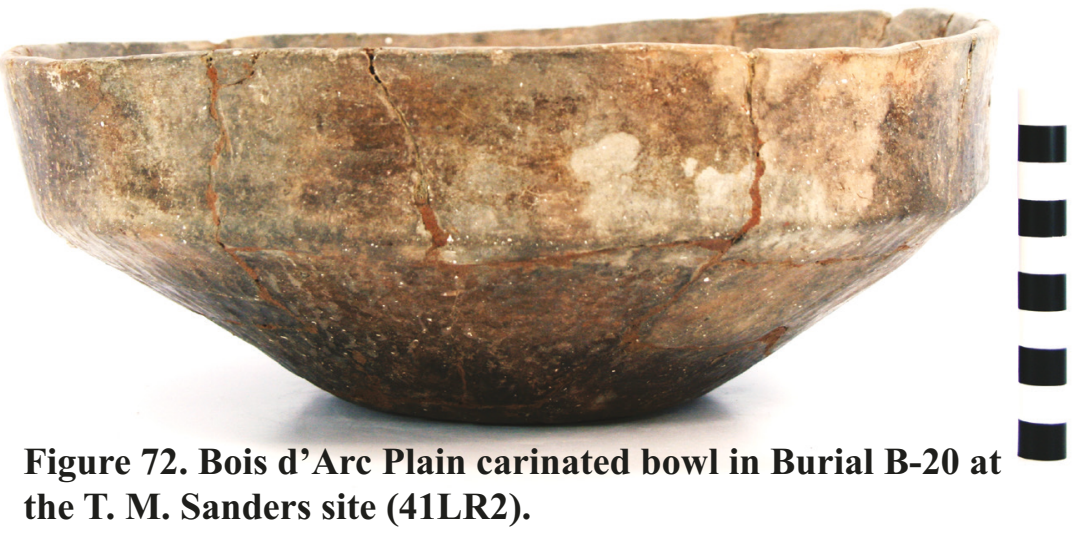


SITE NAME OR SITE NUMBER: T. M. Sanders

VESSEL NO.: 523, Burial B-21

VESSEL FORM: Bowl

NON-PLASTICS AND PASTE: grog

RIM AND LIP FORM: Direct rim and rounded lip

CORE COLOR: F (fired in a reducing environment and cooled in the open air)

INTERIOR SURFACE COLOR: dark yellowish-brown; fire clouds on the base

EXTERIOR SURFACE COLOR: yellowish-brown; fire clouds on the base

WALL THICKNESS (IN MM): rim, $6.1 \mathrm{~mm}$

INTERIOR SURFACE TREATMENT: none

EXTERIOR SURFACE TREATMENT: smoothed

HEIGHT (IN CM): 4.6

ORIFICE DIAMETER (IN CM): 13.6

DIAMETER AT BOTTOM OF RIM

OR NECK (IN CM): N/A

BASE DIAMETER (IN CM) AND SHAPE OF BASE: 7.1; circular and rounded

ESTIMATED VOLUME (IN LITERS):

0.25

DECORATION (INCLUDING MOTIF AND ELEMENTS WHEN

APPARENT): Plain (Figure 73)

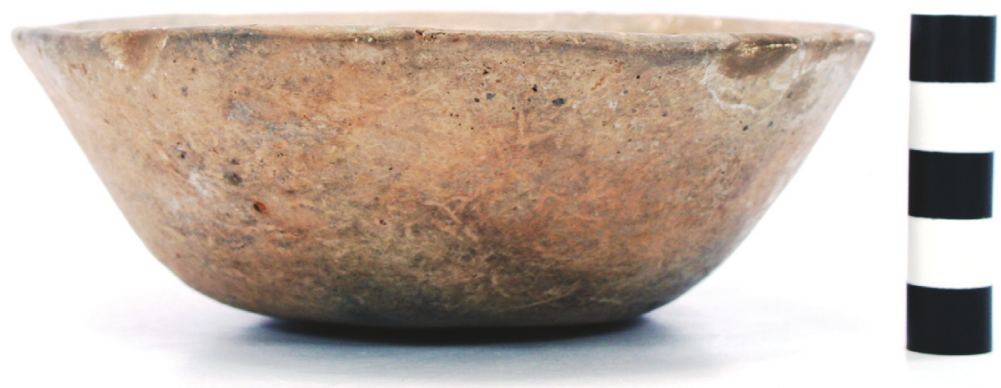

Figure 73. Bois d'Arc Plain bowl in Burial B-21 at the T. M. Sanders site (41LR2).

PIGMENT USE AND

LOCATION ON VESSEL: none

TYPE AND VARIETY (IF KNOWN): Bois d'Arc Plain 
SITE NAME OR SITE NUMBER: T. M. Sanders

VESSEL NO.: 524, Burial B-21

VESSEL FORM: Carinated bowl

NON-PLASTICS AND PASTE: grog

RIM AND LIP FORM: Direct rim and rounded lip

CORE COLOR: F (fired in a reducing environment and cooled in the open air)

INTERIOR SURFACE COLOR: red

EXTERIOR SURFACE COLOR: red

WALL THICKNESS (IN MM): rim, 7.9 mm; body, $6.5 \mathrm{~mm}$; base, $9.4 \mathrm{~mm}$

INTERIOR SURFACE TREATMENT: burnished

EXTERIOR SURFACE TREATMENT: burnished

HEIGHT (IN CM): N/A

ORIFICE DIAMETER (IN CM): 33.0

DIAMETER AT BOTTOM OF RIM OR NECK (IN CM): N/A

BASE DIAMETER (IN CM) AND SHAPE OF BASE: N/A

ESTIMATED VOLUME (IN LITERS): N/A

DECORATION (INCLUDING MOTIF AND ELEMENTS WHEN APPARENT): The interior and exterior surfaces are red-slipped.

PIGMENT USE AND LOCATION ON VESSEL: none

TYPE AND VARIETY (IF KNOWN): Sanders Slipped

\section{Vessels from Miscellaneous Contexts}

There are eight vessels in the T. M. Sanders site collection from miscellaneous contexts. This includes two vessels from a disturbed burial plowed up in 1940, two other vessels that were apparently purchased from the landowner at that time, three vessels from the 1931 University of Texas excavations in the midden deposits between the two earthen mounds (see Jackson 2000), and a vessel donated to the University of Texas in the spring of 1929 by O. L. Crook and Maude Neville from a burial excavated in Mound No. 1 (Jackson n.d.:169-173). 
SITE NAME OR SITE NUMBER: T. M. Sanders

VESSEL NO.: 321, Midden

VESSEL FORM: Carinated bowl, hubcap-style (Figure 74)

NON-PLASTICS AND PASTE: grog

RIM AND LIP FORM: Inverted-everted rim and a rounded lip

CORE COLOR: B (fired and cooled in a reducing environment)

INTERIOR SURFACE COLOR: black

EXTERIOR SURFACE COLOR: black

WALL THICKNESS (IN MM): rim, $3.4 \mathrm{~mm}$; body, $5.1 \mathrm{~mm}$

INTERIOR SURFACE

TREATMENT: burnished on

the rim

EXTERIOR SURFACE

TREATMENT: burnished

HEIGHT (IN CM): 5.5+

ORIFICE DIAMETER (IN

CM): 14.2

DIAMETER AT BOTTOM OF

RIM OR NECK (IN CM): 15.5

BASE DIAMETER (IN CM)

AND SHAPE OF BASE:

Missing

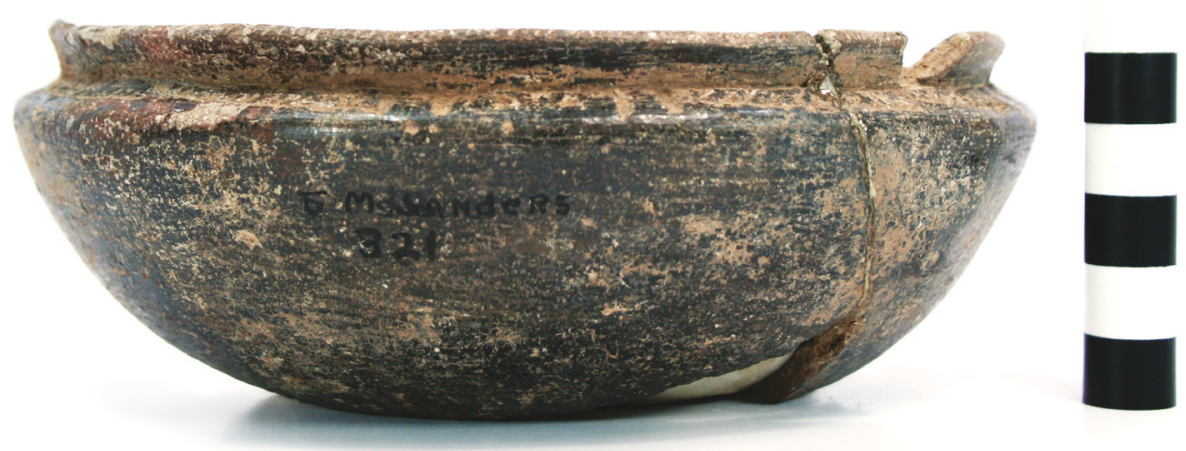

Figure 74. Simms Engraved, var. Darco carinated bowl from midden excavations at the T. M. Sanders site (41LR2).

\section{ESTIMATED VOLUME}

(IN LITERS): 0.46+

DECORATION (INCLUDING MOTIF AND ELEMENTS WHEN APPARENT): The vessel lip is notched, and the rim panel is divided into sections (probably four) by sets of two vertical engraved lines. Between the section dividers are two diagonal (left to right) engraved lines with excised tick marks; to one side of the sets of vertical engraved lines on the rim are two excised triangle elements near the vessel lip (Figure 74).

PIGMENT USE AND LOCATION ON VESSEL: none

TYPE AND VARIETY (IF KNOWN): Simms Engraved, var. Darco 
SITE NAME OR SITE NUMBER: T. M. Sanders

VESSEL NO.: 672, Disturbed burial

VESSEL FORM: Bowl

NON-PLASTICS AND PASTE: grog

RIM AND LIP FORM: Direct rim and rounded lip

CORE COLOR: F (fired in a reducing environment and cooled in the open air)

INTERIOR SURFACE COLOR: red; fire clouds on the body

EXTERIOR SURFACE COLOR: red; fire clouds on the body

WALL THICKNESS (IN MM): rim, $5.4 \mathrm{~mm}$; body, $5.9 \mathrm{~mm}$

INTERIOR SURFACE TREATMENT: smoothed

EXTERIOR SURFACE TREATMENT: burnished

HEIGHT (IN CM): 6.4

ORIFICE DIAMETER (IN CM): 16.0

DIAMETER AT BOTTOM OF RIM OR NECK (IN CM): 15.8

BASE DIAMETER (IN CM) AND SHAPE OF BASE: N/A

ESTIMATED VOLUME (IN LITERS): 0.4

DECORATION (INCLUDING MOTIF AND ELEMENTS WHEN APPARENT): The interior and exterior surfaces of the vessel have been red-slipped.

PIGMENT USE AND LOCATION ON VESSEL: none

TYPE AND VARIETY (IF KNOWN): Sanders Slipped 
SITE NAME OR SITE NUMBER: T. M. Sanders

VESSEL NO.: 673, disturbed burial plowed up in 1940

VESSEL FORM: Deep barrel-shaped bowl with one suspension hole (9.0 $\mathrm{mm}$ in diameter) (Figure 75)

NON-PLASTICS AND PASTE: bone

RIM AND LIP FORM: Everted rim and rounded lip

CORE COLOR: $\mathrm{G}$ (fired in a reducing environment and cooled in the open air)

INTERIOR SURFACE COLOR: very dark grayish-brown

EXTERIOR SURFACE COLOR: dark reddish-brown; fire clouds on the rim and body

WALL THICKNESS (IN MM): rim, 6.9 mm;

body, $7.9 \mathrm{~mm}$

INTERIOR SURFACE TREATMENT:

burnished

EXTERIOR SURFACE TREATMENT:

burnished

HEIGHT (IN CM): N/A

ORIFICE DIAMETER (IN CM): 13.4

DIAMETER AT BOTTOM OF RIM OR

NECK (IN CM): 12.1

BASE DIAMETER (IN CM) AND SHAPE

OF BASE: N/A

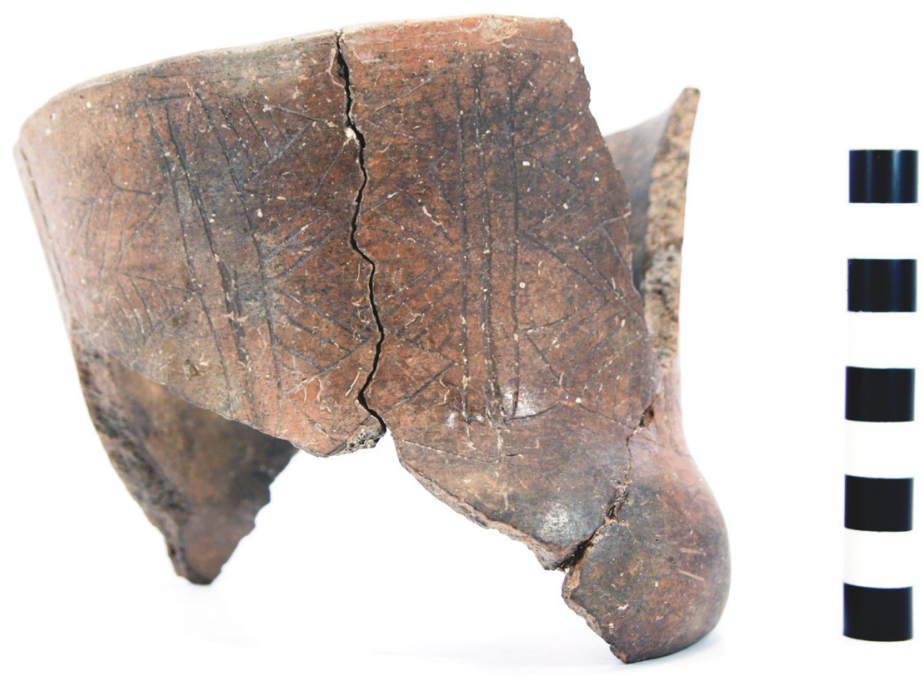

Figure 75. Sanders Engraved bowl in disturbed burial at the T. M. Sanders site (41LR2).

ESTIMATED VOLUME (IN LITERS): N/A

DECORATION (INCLUDING MOTIF AND ELEMENTS WHEN APPARENT): The top part of the rim of the vessel has two horizontal engraved lines. The remainder of the rim is divided into seven panels by sets of three vertical engraved lines. Pendant from the outer engraved lines are large open and hatched (vertical or diagonal in orientation) pendant triangles (Figure 75).

PIGMENT USE AND LOCATION ON VESSEL: none

TYPE AND VARIETY (IF KNOWN): Sanders Engraved 
SITE NAME OR SITE NUMBER: T. M. Sanders

VESSEL NO.: 674, Purchased

VESSEL FORM: Jar with two opposed loop handles (52 x $14 \mathrm{~mm}$ in height and width), each with two vertical lip tabs ("ears") (Figure 76)

NON-PLASTICS AND PASTE: grog

RIM AND LIP FORM: Everted rim and rounded-flattened lip

CORE COLOR: F (fired in a reducing environment and cooled in the open air)

INTERIOR SURFACE COLOR: reddish-brown

EXTERIOR SURFACE COLOR: reddish-brown; fire clouds on the body and base

WALL THICKNESS (IN MM): rim, $6.1 \mathrm{~mm}$

INTERIOR SURFACE

TREATMENT: none

EXTERIOR SURFACE

TREATMENT: none

HEIGHT (IN CM): 11.0

ORIFICE DIAMETER (IN CM): 10.8

DIAMETER AT BOTTOM OF RIM OR NECK (IN CM): 9.0

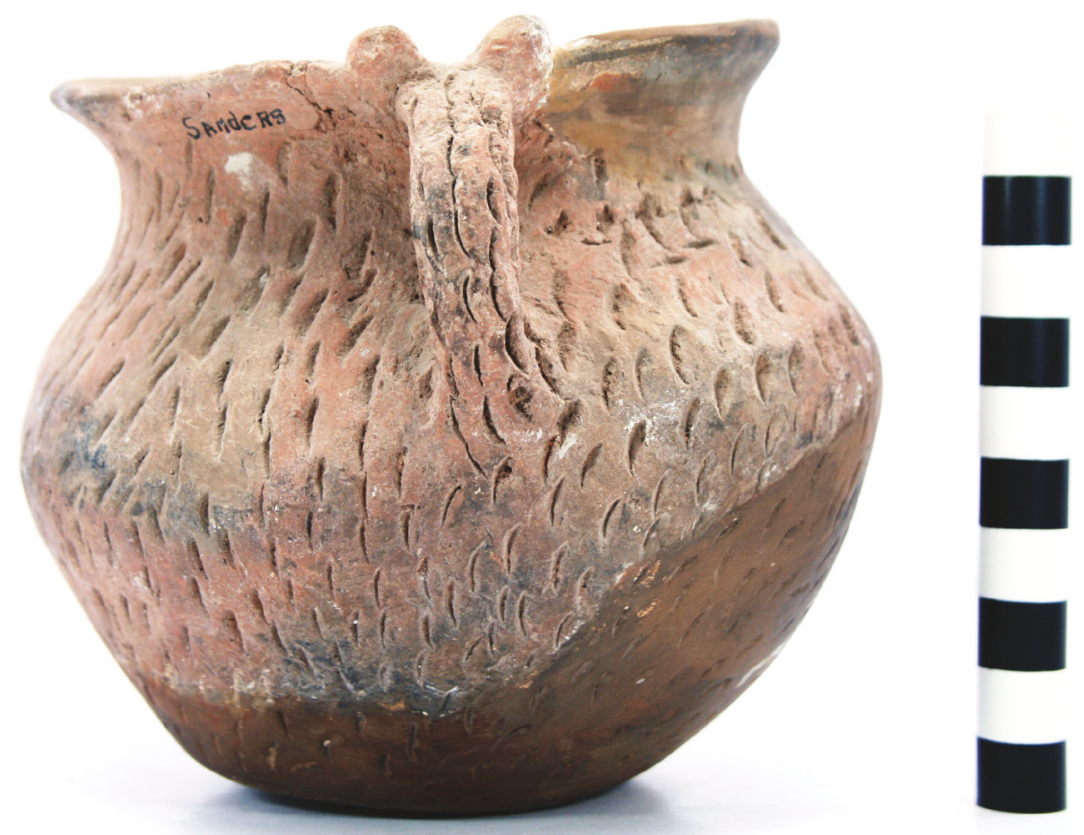

Figure 76. Monkstown Fingernail Impressed jar from the T. M. Sanders site (41LR2).

BASE DIAMETER (IN CM) AND

SHAPE OF BASE: 6.5 ; circular and flat

ESTIMATED VOLUME (IN LITERS): 0.7

DECORATION (INCLUDING MOTIF AND ELEMENTS WHEN APPARENT): The vessel body is decorated with horizontal and vertical rows of fingernail punctations. The loop handles are decorated with three vertical rows of fingernail punctations (Figure 76).

PIGMENT USE AND LOCATION ON VESSEL: none

TYPE AND VARIETY (IF KNOWN): Monkstown Fingernail Impressed 
SITE NAME OR SITE NUMBER: T. M. Sanders

VESSEL NO.: 676

VESSEL FORM: Bottle with a tapered neck

NON-PLASTICS AND PASTE: grog

RIM AND LIP FORM: Direct rim and rounded lip

CORE COLOR: $G$ (fired in a reducing environment and cooled in the open air)

INTERIOR SURFACE COLOR: dark grayish-brown

EXTERIOR SURFACE COLOR: red

WALL THICKNESS (IN MM): rim, $6.2 \mathrm{~mm}$

INTERIOR SURFACE TREATMENT: none

EXTERIOR SURFACE TREATMENT: burnished

HEIGHT (IN CM): 19.5

ORIFICE DIAMETER (IN CM): 3.8

DIAMETER AT BOTTOM OF RIM OR NECK (IN

$\mathrm{CM}$ ): 4.9 ; maximum body diameter is $11.5 \mathrm{~cm}$

BASE DIAMETER (IN CM) AND SHAPE OF BASE: 8.0; circular and rounded

ESTIMATED VOLUME (IN LITERS): 0.6

DECORATION (INCLUDING MOTIF AND

ELEMENTS WHEN APPARENT): The vessel has an exterior red slip, as well as three vertical columns comprised of three sets of appliqued nodes with fingernail punctations between and on the appliqued nodes. Between the appliqued-punctated columns at the top of the vessel body are three horizontal rows of tool punctations (Figure 77).

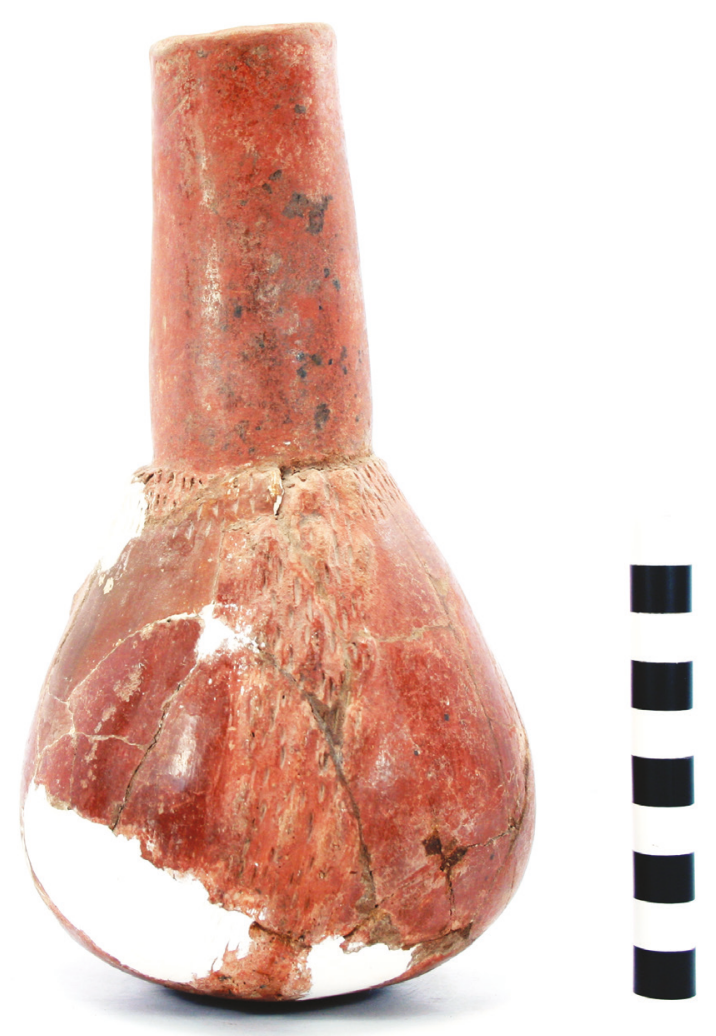

Figure 77. Maxey Noded Redware bottle from the T. M. Sanders site (41LR2).

PIGMENT USE AND LOCATION ON VESSEL: none

TYPE AND VARIETY (IF KNOWN): Maxey Noded Redware 
SITE NAME OR SITE NUMBER: T. M. Sanders

VESSEL NO.: 677, Midden excavations, depth of $36 \mathrm{~cm}$ bs

VESSEL FORM: Carinated bowl

NON-PLASTICS AND PASTE: bone

RIM AND LIP FORM: Direct rim and rounded lip

CORE COLOR: B (fired and cooled in a reducing environment)

INTERIOR SURFACE COLOR: dark grayish-brown

EXTERIOR SURFACE COLOR: very dark grayish-brown

WALL THICKNESS (IN

$\mathrm{MM})$ : rim, $5.7 \mathrm{~mm}$

INTERIOR SURFACE

TREATMENT: smoothed

EXTERIOR SURFACE

TREATMENT: smoothed

HEIGHT (IN CM): 13.4

ORIFICE DIAMETER (IN

$\mathrm{CM}): 34.0$

DIAMETER AT BOTTOM

OF RIM OR NECK (IN

CM): 33.6

Figure 78. Sanders Engraved carinated bowl from midden excavations at the T. M. Sanders site (41LR2).

BASE DIAMETER (IN

CM) AND SHAPE OF

BASE: 9.5; circular and flat

ESTIMATED VOLUME (IN LITERS): 4.1

DECORATION (INCLUDING MOTIF AND ELEMENTS WHEN APPARENT): The rim is decorated with 15 sets of diagonal opposed engraved lines that form triangle elements with five diagonal lines on each side of the triangle (Figure 78).

PIGMENT USE AND LOCATION ON VESSEL: none

TYPE AND VARIETY (IF KNOWN): Sanders Engraved 
SITE NAME OR SITE NUMBER: T. M. Sanders

VESSEL NO.: 678, donated by O. L. Crook and Maude Neville; vessel recovered in or near a flexed burial in Mound No. 1 that was excavated in the spring of 1929 (Jackson n.d.:169-173).

VESSEL FORM: Carinated bowl

NON-PLASTICS AND PASTE: grog

RIM AND LIP FORM: Direct rim and rounded lip

CORE COLOR: F (fired in a reducing environment and cooled in the open air)

INTERIOR SURFACE COLOR: red

EXTERIOR SURFACE COLOR: red; fire clouds on the base

WALL THICKNESS (IN MM): rim, $7.4 \mathrm{~mm}$; body, $5.7 \mathrm{~mm}$; base, $6.4 \mathrm{~mm}$

INTERIOR SURFACE TREATMENT: burnished

EXTERIOR SURFACE TREATMENT: burnished

HEIGHT (IN CM): 8.9

ORIFICE DIAMETER (IN CM): 28.0

DIAMETER AT BOTTOM OF RIM OR NECK (IN CM): 28.0

BASE DIAMETER (IN CM) AND SHAPE OF BASE: N/A

ESTIMATED VOLUME (IN LITERS): 1.5

DECORATION (INCLUDING MOTIF AND ELEMENTS WHEN APPARENT): The rim is decorated with a continuous series of right to left diagonal engraved lines (Figure 79).

PIGMENT USE AND LOCATION ON VESSEL: none

TYPE AND VARIETY (IF KNOWN): Sanders Engraved

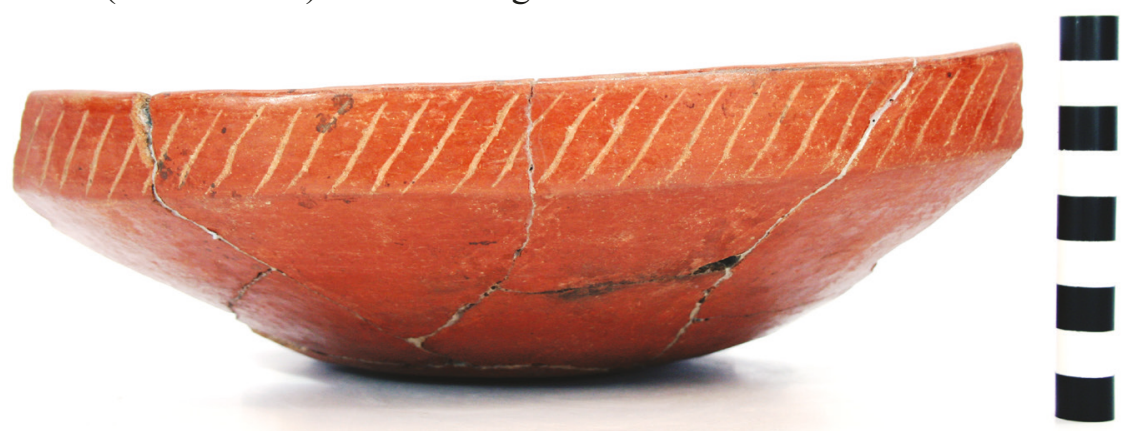

Figure 79. Sanders Engraved carinated bowl from the T. M. Sanders site (41LR2). 
SITE NAME OR SITE NUMBER: T. M. Sanders

VESSEL NO.: 679, from midden excavations

VESSEL FORM: Jar

NON-PLASTICS AND PASTE: bone

RIM AND LIP FORM: Everted rim and rounded lip

CORE COLOR: B (fired and cooled in a reducing environment)

INTERIOR SURFACE COLOR: very dark grayish-brown; fire clouds on the rim

EXTERIOR SURFACE COLOR: very dark grayish-brown; fire clouds on the rim and body

WALL THICKNESS (IN MM): rim, 6.5 $\mathrm{mm}$; body, $5.3 \mathrm{~mm}$

INTERIOR SURFACE TREATMENT: smoothed

EXTERIOR SURFACE TREATMENT: smoothed on the body

HEIGHT (IN CM): N/A; rim height is $6.4 \mathrm{~cm}$

ORIFICE DIAMETER (IN CM): 28.0

DIAMETER AT BOTTOM OF RIM OR NECK (IN CM): 27.2

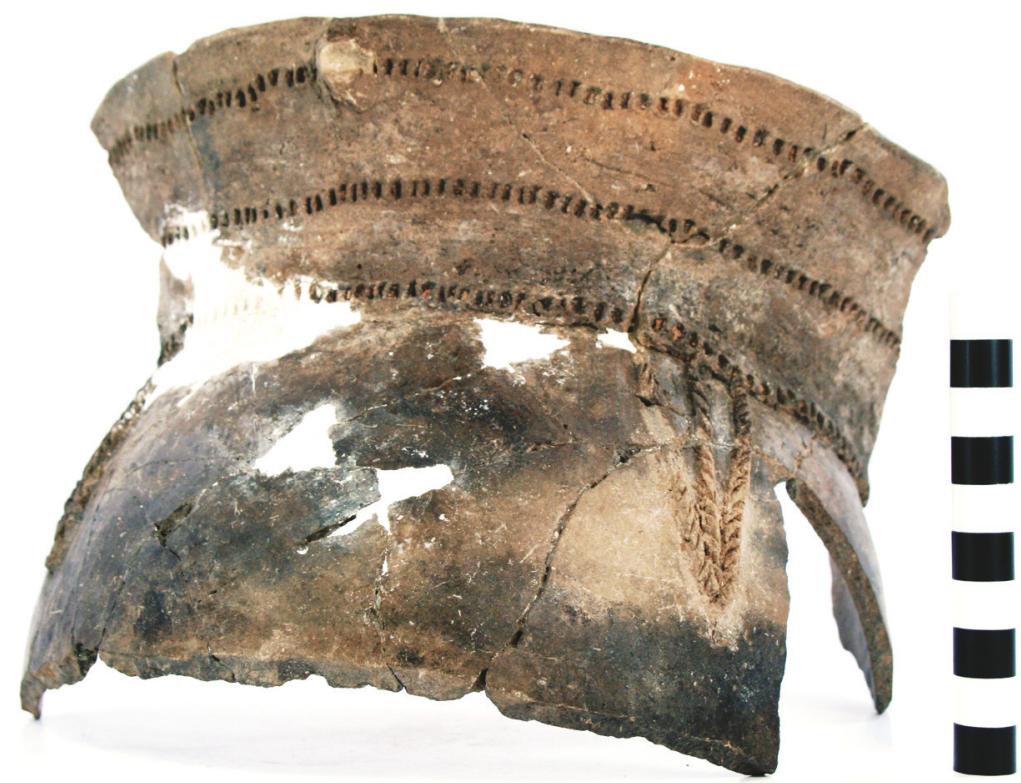

Figure 80. Emory Punctated jar from midden excavations at the T. M. Sanders site (41LR2).

BASE DIAMETER (IN CM) AND

SHAPE OF BASE: N/A

ESTIMATED VOLUME (IN LITERS): N/A

DECORATION (INCLUDING MOTIF AND ELEMENTS WHEN APPARENT): The rim is decorated with three rows of tool punctations, as well as one large appliqued node (13 $\mathrm{mm}$ in diameter) on top of the uppermost tool punctated row. The vessel body has triangular-shaped appliqued fillet elements; there are likely four such elements on the vessel body (Figure 80).

PIGMENT USE AND LOCATION ON VESSEL: none

TYPE AND VARIETY (IF KNOWN): Emory Punctated 


\section{Summary and Conclusions}

The T. M. Sanders site (41LR2) is a significant ancestral Caddo mound center and settlement on an alluvial terrace of the Red River below its confluence with Bois d'Arc Creek in the Post Oak Savannah of East Texas. Archaeological investigations at the site in 1931 by the University of Texas, following excavations in one (Mound No. 1 or the East Mound) of the two mounds at the site by the landowner, recovered a substantial assemblage of 78 Caddo vessels from mound and midden excavations; most of the vessels were recovered as funerary offerings in burial features in Mound No. 1. With the exception of two vessels from midden excavations that are associated with a late $17^{\text {th }}$ to early $18^{\text {th }}$ century Caddo occupation (see Perttula et al. 2015), the remaining 76 vessels are part of a single cultural component associated with the Middle Caddo period, Sanders phase, occupation of the T. M. Sanders site.

\section{Ceramic Taxonomy of the Vessels from the T. M. Sanders Site}

As discussed below, the principal ceramic types at the T. M. Sanders site include Sanders Engraved, Maxey Noded Redware, and a number of plain $(n=23)$ and slipped $(n=6)$ vessels. In our redefinition of the ceramic taxonomy of the vessels from the site, the plain and slipped wares are assigned new type names, and several of the incised bowls and carinated bowls are included in a newly defined type.

As redefined by Brown (1996:401-403 and Figures 2-191, 2-34g, 2-37a-1, 2-38d, 2-39d, k, n-q, and 2-42b), Sanders Plain was considered a grog-tempered, slipped, and undecorated type found widely across the Caddo area. Vessel forms include bowls, carinated bowls, and narrow, and wide-mouthed bottles. Because the key attribute of the Sanders Plain type was the fact that vessels of the type had slipped surfaces, rather than that they were plain, based on our analysis of the ceramic vessels from the Sanders site, we have renamed the type as Sanders Slipped, so that there is no confusion about the decorative elements represented in this type.

In the case of the non-slipped plain grog- and/or bone-tempered wares from the T. M. Sander site subsumed within either earlier Sanders Plain or Paris Plain (see Brown 1996) typological labels, we have redefined them as Bois d'Arc Plain. One distinct class of plain vessels in the vessel assemblage, with scalloped and cut lips, has been defined as Bois d'Arc Plain, var. Crawford.

Finally, three incised bowls and carinated bowls in the vessel assemblage are included in a new type: Sanders Incised. The decorative elements on these vessels are the same as noted on a number of the Sanders Engraved vessels at the site, except that they are executed in a wet paste, not in an engraved method after the vessel was leather-hard or already fired.

\section{Middle Caddo Period Ceramic Vessels from the T. M. Sanders Site}

Ten different ceramic types, and a newly defined variety of one type, comprise the recognized ceramic types in the Middle Caddo period vessel assemblage at the T. M. Sanders site (Table 2). Plain wares comprise 30.3 percent of the vessels, utility wares another 13.1 percent, and the remaining 56.6 percent of the ceramic vessels from the site are fine wares with either engraved or red-slipped decorative elements. The principal types are Bois d'Arc Plain, Sanders Engraved, Maxey Noded Redware, and Sanders Slipped. The Haley Engraved vessel is likely a trade vessel made by a Haley phase Caddo potter in the Great Bend area of the Red River basin, well downstream from the T. M. Sanders site. The East Incised and Hickory Engraved vessels in burials at the site may also be trade vessels whose source is elsewhere in the southern Caddo area. 
Table 2. Ceramic types in the Middle Caddo period component at the T. M. Sanders site.

\begin{tabular}{lll}
\hline Type & No. & Percent \\
\hline Bois d'Arc Plain & 19 & 25.0 \\
Bois d'Arc Plain, var. Crawford & 4 & 5.3 \\
Canton Incised & 2 & 2.6 \\
East Incised & 1 & 1.3 \\
Haley Engraved & 1 & 1.3 \\
Hickory Engraved & 1 & 1.3 \\
Maxey Noded Redware & 12 & 15.8 \\
Monkstown Fingernail Impressed & 4 & 5.3 \\
Sanders Engraved & 16 & 21.1 \\
Sanders Incised & 3 & 3.9 \\
Sanders Slipped & 6 & 7.9 \\
\hline Totals & 69 & 100.0 \\
\hline
\end{tabular}

There are seven ceramic vessels (9.2 percent) in this component (i.e., they are from burials excavated in Mound No. 1) that have not been assigned to a defined type. These include one shell-tempered olla with appliqued nodes and fillets and a plain shell-tempered jar that may have made by a Plains Village period Southern Plains community upstream on the Red River.

A unique red-painted conjoined bottle-jar in Burial 15 is likely a trade vessel of Angel Negative Painted that originated in the Angel Mounds area in the lower Ohio River valley (Baumann et al. 2013:Figure 1). The Angel Mound site was occupied from cal. A.D. 1050-1420 (Monaghan et al. 2013), generally contemporaneous with the T. M. Sanders site.

Other typologically unidentified ceramic vessels are either grog or bone-tempered utility wares $(n=3)$ or fine wares $(n=1)$. The utility wares include a jar in Burial 5 with large incised triangle decorative elements, another jar in Burial 5 with appliqued ridge triangle elements, and a bottle in Burial 12 with appliqued nodes and fillets. The one fine ware vessel is a carinated bowl with sets of vertical engraved lines on the rim and a series of erratically executed diagonal and cross-hatched engraved lines on the vessel body.

In the defined ceramic types in the Middle Caddo period component at the T. M. Sanders site, there are five ceramic vessel forms among the plain, utility, and fine wares (Table 3). Bottles and neckless bottles account for 30.4 percent of these vessels, as do bowls, while 24.6 percent of the vessels are carinated bowls, and the remaining 14.5 percent of the vessels are jars. The majority of the bottles are Maxey Noded Redware vessels, and all four of the distinctive neckless bottles are of the Sanders Engraved type. About half of the Bois d'Arc Plain vessels are bowls, 33 percent of the Sanders Incised vessels are bowls, and 67 percent of the Sanders Slipped vessels are bowls. Only 19 percent of the Sanders Engraved vessels are bowls (Table 3 ).

Table 3. Vessel forms represented in the defined ceramic types in the Middle Caddo period component at the T. M. Sanders site.

\begin{tabular}{lllllll}
\hline Type & $\mathrm{Bt}$ & $\mathrm{Nk}-\mathrm{Bt}$ & $\mathrm{Bw}$ & $\mathrm{CB}$ & $\mathrm{J}$ & $\mathrm{N}$ \\
\hline Bois d'Arc Plain & 3 & - & 9 & 5 & 2 & 19 \\
Bois d'Arc, var. & - & - & 2 & 2 & - & 4 \\
Crawford & & & & & &
\end{tabular}


Table 3. Vessel forms represented in the defined ceramic types in the Middle Caddo period component at the T. M. Sanders site, cont.

\begin{tabular}{lllllll}
\hline Type & Bt & Nk-Bt & Bw & CB & J & N \\
\hline Canton Incised & - & - & - & - & 2 & 2 \\
East Incised & - & - & 1 & - & - & 1 \\
Haley Engraved & 1 & - & - & - & - & 1 \\
Hickory Engraved & - & - & 1 & - & - & 1 \\
Maxey Noded & 12 & - & - & - & - & 12 \\
$\quad$ Redware & - & - & - & - & 4 & 4 \\
$\quad$ Monkstown & - & 4 & 3 & 7 & 2 & 16 \\
$\quad$ Fingernail Impressed & - & - & 1 & 2 & - & 3 \\
Sanders Engraved & 1 & - & 4 & 1 & - & 6 \\
Sanders Incised & 17 & 4 & 21 & 17 & 10 & 69 \\
\hline Sanders Slipped & Totals & & & & & \\
\hline
\end{tabular}

$\mathrm{Bt}=$ bottle; $\mathrm{Nk}-\mathrm{Bt}=$ neckless bottle; $\mathrm{Bw}=$ bowl; $\mathrm{CB}=$ carinated bowl; $\mathrm{J}=\mathrm{jar}$

Carinated bowls are well represented in the Sanders Incised (67 percent) and Sanders Engraved (44 percent) types, and also occur among the Bois d'Arc Plain (26 percent), Bois d'Arc Plain, var. Crawford (50 percent), and Sanders Slipped (17 percent) vessels (see Table 3). All of the Canton Incised and Monkstown Fingernail Impressed vessels in the T. M. Sanders vessel assemblage are jars, as are 10.5 percent of the Bois d'Arc Plain vessels. A total of 12.5 percent of the Sanders Engraved vessels are also jars.

Approximately 69.5 percent of the defined ceramic type vessels in the Middle Caddo period component at the T. M. Sander site are tempered with grog (i.e., crushed sherds or fired clay) (Table 4). Another 18.8 percent of these vessels are tempered with grog and crushed burned bone, and the remaining 11.6 percent are tempered only with crushed and burned bone.

Table 4. Different tempers represented in the defined ceramic types in the Middle Caddo period component at the T. M. Sanders site.

\begin{tabular}{lllll}
\hline Type & Grog & Grog-bone & Bone & N \\
\hline Bois d'Arc Plain & 15 & 3 & 1 & 19 \\
Bois d'Arc, var. Crawford & 1 & 3 & - & 4 \\
Canton Incised & 1 & 1 & - & 2 \\
East Incised & 1 & - & - & 1 \\
Haley Engraved & - & - & 1 & 1 \\
Hickory Engraved & - & 5 & 1 & 1 \\
Maxey Noded Redware & 6 & - & 1 & 12 \\
Monkstown Fingernail Impressed & 4 & 1 & - & 4 \\
Sanders Engraved & 12 & - & - & 3 \\
Sanders Incised & 3 & - & 1 & 6 \\
Sanders Slipped & 5 & 13 & 8 & 69 \\
\hline Totals & 48 & & & 3 \\
\hline
\end{tabular}


Including vessels with grog and bone temper, with those tempered only with bone, the use of bone as a temper in the manufacture of vessels in use was most prevalent in Bois d'Arc Plain, var. Crawford (75 percent), Maxey Noded Redware (50 percent), Canton Incised (50 percent), and Sanders Engraved (25 percent) (see Table 4). Only 21.1 percent of the Bois d'Arc Plain vessels are bone-tempered, 16.7 percent of the Sanders Slipped vessels are bone-tempered, and none of the Sanders Incised or Monkstown Fingernail Impressed vessels were manufactured with bone temper.

The vessels in the Middle Caddo period Sanders phase component at the T. M. Sanders site were made in a variety of sizes (and volumes). There are three sizes of bottles, about 88 percent of which are less than 1.0 liter in volume (Table 5). Neckless bottles (of the Sanders Engraved type) are larger than the regular bottle form, with volumes that range from 1.1-4.0 liters. Bowls are generally small: 60 percent have volumes less than 0.5 liters, and another 25 percent have volumes between 0.51-1.0 liters. However, two of the bowls (10 percent) are extra large, with volumes greater than 4.0 liters (Table 5): these are a Sanders Slipped and Bois d'Arc Plain, var. Crawford vessels.

Table 5. Estimated volume (in liters) of vessel forms in the Middle Caddo period component at the T. M. Sanders site.

\begin{tabular}{lllllll}
\hline Vessel Form & $<0.5 \mathrm{~L}$ & $0.51-1.0 \mathrm{~L}$ & $1.1-2.0 \mathrm{~L}$ & $2.1-4.0 \mathrm{~L}$ & $+4 \mathrm{~L}$ & $\mathrm{~N}$ \\
\hline Bottle & 9 & 7 & 2 & - & - & 18 \\
Neckless Bottle & - & - & 3 & 1 & - & 4 \\
Bowl & 12 & 5 & - & 1 & 2 & 20 \\
Carinated Bowl & - & 2 & 2 & 7 & 6 & 17 \\
Jar & 2 & 6 & 1 & 1 & 2 & 12 \\
\hline Totals & 23 & 20 & 8 & 10 & 10 & 71 \\
\hline
\end{tabular}

$\mathrm{L}=$ liters

Carinated bowls were made in at least four sizes (see Table 5) and they are generally large in volume: 23.5 percent have volumes less than 1.0 liter, 11.8 percent have volumes between 1.1-2.0 liters, and 76.5 percent of the carinated bowls have volumes greater than 2.0 liters. The very largest carinated bowls (with volumes greater than 4.0 liters) include two Sanders Engraved, three Bois d'Arc Plain, and one Bois d'Arc Plain, var. Crawford vessels.

Jars in the Middle Caddo period component at the T. M. Sanders site were also made in a range of sizes. The majority of the jars are small, less than 1.0 liter in volume (67 percent, see Table 5). Twenty-five percent of the jars have large (greater than 2.0 liters) in volume, and 16.7 percent have volumes greater than 4.0 liters: this includes a Canton Incised jar and a Monkstown Fingernail Impressed jar. The Canton Incised jar is the largest vessel by volume in the Middle Caddo period assemblage at 10.5 liters.

The burials in the Mound No. 1 excavations at the T. M. Sanders site that have the very largest vessels (Burials 4, 9, 11, and 20) are each situated in features at the crest of the mound (see Figure 4); these features also include numbers of marine shell gorgets, beads, discs, and pendants. Three of the burial features have only a single interment, but Burial 20 has four individuals (see Jackson et al. 2000:31), and the largest number of vessels, the numerous marine shell artifacts, and stone ear plugs. It is likely that these burials represent religious and/or political leaders in the Sanders site Caddo community.

Forty-five percent of the vessels in these burials have volumes greater than 4.0 liters. This includes 50 percent of the vessels in Burial 4, 43 percent in Burial 9, 50 percent in Burial 11, and 29 percent of the 
vessels in Burial 20. The religious and/or political elites buried in these graves at the T. M. Sanders site were well-gifted for food stuffs on their journey to the House of the Dead in the Sky.

The other extra large vessel in the Middle Caddo period vessel assemblage from the T. M. Sanders site is a Sanders Engraved carinated bowl from excavations in the midden deposits between the two mounds.

\section{Historic Caddo Period Ceramic Vessels from the T. M. Sanders Site}

Only two vessels (2.6 percent) in the T. M. Sanders site vessel assemblage are from the Historic Caddo period component. They include a hubcap-style (cf. Story et al. 1967:Figure 53a) Simms Engraved carinated bowl with grog temper and an Emory Punctated-Incised (see Story et al. 1967:136-139 and Figure $57 \mathrm{~g}-\mathrm{i})$ bone-tempered jar. Both vessels were recovered in the midden excavations between the two mounds, likely in unrecorded or unrecognized burial features there. 


\section{References Cited}

Baumann, T. E., T. L. Gerke, and E. A. Reber

2013 Sun Circles and Science: Negative Painted Pottery from Angel Mounds (12Vg1). Midcontinental Journal of Archaeology 38(2):219-244.

Bell, R. E. and D. A. Baerreis

1951 A Survey of Oklahoma Archaeology. Bulletin of the Texas Archeological and Paleontological Society 22:7-100.

Bell, R. E., E. B. Jelks, and W. W. Newcomb (assemblers)

1967 A Pilot Study of Wichita Indian Archeology and Ethnohistory. Final Report for Grant GS-964, National Science Foundation, Washington, D.C.

Brown, J. A.

1996 The Spiro Ceremonial Center: The Archaeology of Arkansas Valley Caddoan Culture in Eastern Oklahoma. 2 Vols. Memoirs No. 29. Museum of Anthropology, The University of Michigan, Ann Arbor.

Bruseth, J. E.

1998 The Development of Caddoan Polities along the Middle Red River Valley of Eastern Texas and Oklahoma. In The Native History of the Caddo: Their Place in Southeastern Archeology and Ethnohistory, edited by T. K. Perttula and J. E. Bruseth, pp. 47-68. Studies in Archeology 30. Texas Archeological Research Laboratory, The University of Texas at Austin.

Bruseth, J. E., D. E. Wilson, and T. K. Perttula

1995 The Sanders Site: A Spiroan Entrepot in Texas? Plains Anthropologist 40(153):223-236.

Chelf, C.

1939 A Group Burial from Lamar County. Information Circular No. 6. Texas Memorial Museum, Austin.

Ferring, C. R. and T. K. Perttula

1987 Defining the Provenance of Red-Slipped Pottery from Texas and Oklahoma by Petrographic Methods. Journal of Archaeological Science 14:437-456.

Hamilton, D. L.

1997 Observations on Caddoan Burial Practices at the Sanders Site (41LR2). Bulletin of the Texas Archeological Society 68:115-134.

Hanna, H., Jr.

1950 Three Burials from Mound 2, T. M. Sanders Site. The Record 8(4):16-19. Dallas Archeological Society, Dallas.

Harris, R. K.

1953 Two Recent Trips to Sites in Fannin and Lamar Counties. The Record 11(5):19-20. Dallas Archeological Society, Dallas.

Harris, R. K. and I. M. Harris

1967 Trade Beads, Projectile Points, and Knives. In A Pilot Study of Wichita Indian Archeology and Ethnohistory, assembled by R. E. Bell, E. B. Jelks, and W. W. Newcomb, pp. 129-162. Final report for Grant GS-964, National Science Foundation, Washington, D.C.

Harris, R. K., I. M. Harris, J. C. Blaine, and J. Blaine

1965 A Preliminary Archeological and Documentary Study of the Womack Site, Lamar County, Texas. Bulletin of the Texas Archeological Society 36:287-363.

Housewright, R.

1940 A Multiple Burial in Lamar County. The Record 2(8):37-39. Dallas Archeological Society, Dallas. 
Jackson, A. T.

n.d. Laboratory Study of the Material Culture, T. M. Sanders Site, Lamar County, Texas. MS on file, Texas Archeological Research Laboratory, The University of Texas at Austin.

2000 Notes on Fieldwork, T. M. Sanders Farm, Lamar County, Texas. In The 1931 Excavations at the Sanders Site, Lamar County, Texas: Notes on the Fieldwork, Human Osteology, and Ceramics, by A. T. Jackson, M. S. Goldstein, and A. D. Krieger, pp. 9-92. Archival Series No. 2. Texas Archeological Research Laboratory, The University of Texas at Austin.

Jackson, A. T., M. S. Goldstein, and A. D. Krieger

2000 The 1931 Excavations at the Sanders Site, Lamar County, Texas: Notes on the Fieldwork, Human Osteology, and Ceramics. Archival Series 2. Texas Archeological Research Laboratory, The University of Texas at Austin.

Jurney, D. H. and W. Young

1995 Southwestern Pottery and Turquoise in Northeastern Texas. Caddoan Archeology Newsletter 6(2):15-28.

Krieger, A. D.

1946 Culture Complexes and Chronology in Northern Texas, with Extensions of Puebloan Datings to the Mississippi Valley. Publication No. 4640. The University of Texas, Austin.

2000 The Pottery of the Sanders Farm. In The 1931 Excavations at the Sanders Site, Lamar County, Texas: Notes on the Fieldwork, Human Osteology, and Ceramics, by A. T. Jackson, M. S. Goldstein, and A. D. Krieger, pp. 131-144. Archival Series 2. Texas Archeological Research Laboratory, The University of Texas at Austin.

2009 Archaeological Horizons in the So-Called Caddo Area. Archival Series 3. Texas Archeological Research Laboratory, The University of Texas at Austin.

Maples, W. R.

1962 A Morphological Comparison of Skeletal Material from Sanders Focus and from Fulton Aspect. Master's thesis, Department of Anthropology, The University of Texas at Austin.

Monaghan, G. W., T. Schilling, A. M. Krus, and C. S. Peebles

2013 Mound Construction Chronology at Angel Mounds: Episodic Mound Construction and Ceremonial Events. Midcontinental Journal of Archaeology 38(2):155-170.

Pearce, J. E. and A. T. Jackson

1931 Notes on Field Work T. M. Sanders Farm, Lamar County, Texas, July 23 to August 29, 1931. MS on file, Texas Archeological Research Laboratory, The University of Texas at Austin.

Perttula, T. K.

1997 Sabine River and Middle Red River Ceramics: Musings on the Ceramic Data used in Schambach's "Continuing the Discussion of the Spiroans and Their Entrepots." Caddoan Archeology 8(3):9-18.

2012 The Archaeology of the Caddo in Southwest Arkansas, Northwest Louisiana, Eastern Oklahoma, and East Texas: An Introduction to the Volume. In The Archaeology of the Caddo, edited by T. K. Perttula and C. P. Walker, pp. 1-25. University of Nebraska Press, Lincoln.

2013 Analysis of a Small Sample of Caddo Ceramic Sherds from the T. M. Sanders Site (41LR2), Lamar County, Texas. Journal of Northeast Texas Archaeology 39:1-5.

2015 East Texas Caddo Ceramic Sherd Database. Journal of Northeast Texas Archaeology 51:1-46.

Perttula, T. K. and P. S. Marceaux

2011 Archeological Survey Investigations on the Crawford Property and a Portion of the T. M. Sanders Site (41LR2) in the New Proposed Right-of-Way for the Keystone XL Pipeline, Lamar County, Texas. Letter Report No. 280. Archeological \& Environmental Consultants, LLC, Austin.

Perttula, T. K. and B. Nelson

2016 Further Surface Collecting and Shovel Testing Investigations at the Sanders Site (41LR2), Lamar County, Texas. Journal of Northeast Texas Archaeology 60, in press. 
Perttula, T. K. and R. Z. Selden Jr.

2014 Ancestral Caddo Ceramics in East Texas. Journal of Northeast Texas Archaeology 48:9-58.

Perttula, T. K., P. S. Marceaux, B. Nelson, and M. Walters

2015 Caddo Ceramic Vessels from Sites in the Upper Neches River Basin of East Texas, Anderson and Cherokee Counties, Texas. Special Publication No. 37. Friends of Northeast Texas Archaeology, Austin and Pittsburg.

Perttula, T. K., B. Nelson, and R. Z. Selden Jr.

2013 Documentation of Cemeteries and Funerary Offerings from Sites in the Upper Neches River Basin, Anderson, Cherokee, and Smith Counties, Texas. Special Publication No. 26. Friends of Northeast Texas Archaeology, Pittsburg and Austin.

Perttula, T. K., B. Nelson, M. Walters, and R. Z. Selden Jr.

2015 The Sanders Site (41LR2): A Middle to Historic Caddo Settlement and Mound Center on the Red River in Lamar County, Texas. Journal of Northeast Texas Archaeology 50:1-87.

Peyton, A.

2013 Interim Report: Results of Archaeological Significance Testing at the Sanders Site (41LR2), Lamar County, Texas. SWCA Environmental Consultants, Austin.

Rice, P. M.

1987 Pottery Analysis: A Sourcebook. University of Chicago Press, Chicago.

Rohn, A. H.

1998 Haley's Point (34MA15) on the Red River, Marshall County, Oklahoma (Area F). Publications in Anthropology No. 4. Wichita State University, Wichita.

Schambach, F. F.

1995 A Probable Spiroan Entrepot in the Red River Valley in Northeast Texas. Caddoan Archeology Newsletter 6(1):9-25.

1998 Pre-Caddoan Cultures of the Trans-Mississippi South. Research Series 53. Arkansas Archeological Survey, Fayetteville.

1999 Deconstructing the "Sanders Focus" and "Sanders Phase": A Reply to Perttula Regarding the Taxonomy and Significance of the So-Called Sanders Focus, or Sanders Phase Pottery of Northeast Texas and Southeast Oklahoma. Caddoan Archeology 9(3-4):3-55.

2000a The Significance of the Sanders Site in the Culture History of the Mississippi Period Southeast and the Southern Plains. In The 1931 Excavations at the Sanders Site, Lamar County, Texas: Notes on the Fieldwork, Human Osteology, and Ceramics, by A. T. Jackson, M. S. Goldstein, and A. D. Krieger, pp. 1-7. Archival Series 2. Texas Archeological Research Laboratory, The University of Texas at Austin.

2000b Spiroan Traders, the Sanders Site, and the Plains Interaction Sphere: A Reply to Bruseth, Wilson, and Perttula. Plains Anthropologist 45(171):17-33.

Skibo, J. M.

1992 Pottery Function: A Use-Alteration Perspective. Plenum Press, New York.

Story, D. A., B. Barber, E. Cobb, H. Cobb, R. Coleman, K. Gilmore, R. K. Harris, and N. Hoffrichter

1967 Pottery Vessels. In “The Gilbert Site: A Norteno Focus Site in Northeast Texas," edited by E. B. Jelks. Bulletin of the Texas Archeological Society 37:112-187.

Suhm, D. A. and E. B. Jelks (editor)

1962 Handbook of Texas Archeology: Type Descriptions. Special Publication No. 1, Texas Archeological Society, and Bulletin No. 4, Texas Memorial Museum, Austin. 
Teltser, P. A.

1993 An Analytic Strategy for Studying Assemblage-Scale Ceramic Variation: A Case Study from Southeast Missouri. American Antiquity 58(3):530-543.

Wilson, D.

1993 The Sexual Division of Labor at the Sanders Site (41LR2), Lamar County Texas. Caddoan Archeology Newsletter 4(3):6-13.

1994 Division of Labor and Stress Loads at the Sanders Site (41LR2), Lamar County, Texas. Bulletin of the Texas Archeological Society 65:129-160.

1995 Dental Paleopathologies in the Sanders Site (41LR2) Population from Lamar County. Journal of Northeast Texas Archaeology 5:29-59.

1997 Dental Paleopathology in the Sanders (41LR2) and Mitchell (41BW4) Populations from the Red River Valley, Northeast Texas. Bulletin of the Texas Archeological Society 68:147-159.

Wilson, D., and D. Cargill

1993 Stable Isotope Analysis from the Sanders Site (41LR2). Caddoan Archeology Newsletter 4(3):3.

Wilson, D., and S. Derrick

1996 Cranial Modeling Among the Caddo. The Newsletter of the Friends of the Texas Archeological Research Laboratory 4(2):20-21.

Wilson, L.

1948 Two Small Pipes from the Sanders Site near Direct. The Record 6(7):30. Dallas Archeological Society, Dallas.

Wilson, L., and R. Housewright

1941 Scrapers from Sanders Site, Lamar County. The Record 3(4):19-21. Dallas Archeological Society, Dallas. 